
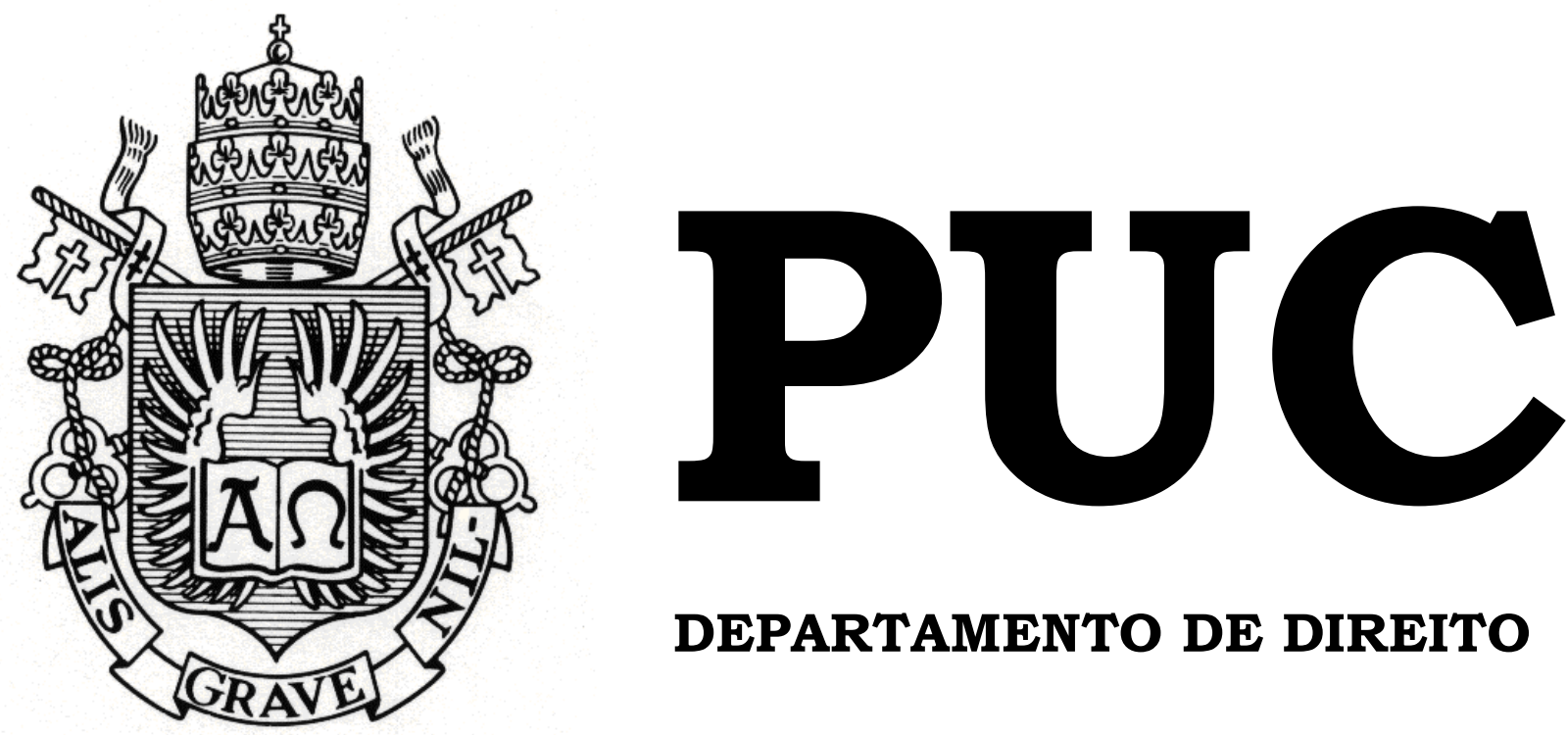

DEPARTAMENTO DE DIREITO

UMA ANÁLISE SOBRE OS MECANISMOS DE DISSOCIAÇÃO DO PODER ECONÔMICO E PARTICIPAÇÃO POLIÍTICA NAS COMPANHIAS BRASILEIRAS

\author{
Por \\ GABRIEL RAMALHO MEDEIROS
}

ORIENTADOR: Francisco Antunes Maciel Mussnich 2018.2

PONTIFÍCIA UNIVERSIDADE CATÓLICA DO RIO DE JANEIRO RUA MARQUÊS DE SÃO VICENTE, 225 - CEP 22451-900 RIO DE JANEIRO - BRASIL 


\title{
UMA ANÁLISE SOBRE OS MECANISMOS DE DISSOCIAÇÃO DO PODER ECONÔMICO E PARTICIPAÇÃO POLÍTICA NAS COMPANHIAS BRASILEIRAS
}

por

\section{GABRIEL RAMALHO MEDEIROS}

\author{
Monografia apresentada ao \\ Departamento de Direito da \\ Pontificia Universidade Católica do \\ Rio de Janeiro (PUC-Rio) para a \\ obtenção do Título de Bacharel em \\ Direito.
}

Orientador: Francisco Antunes Maciel Mussnich 
"A meditação filosófica sobre o direito e o poder, em suas matrizes primeiras, encontra sempre a ambivalência do ser humano, buscando novas formas de equilíbrio entre as forças que o prendem ao passado e as que impelem para o futuro, oscilando entre a ordem estática e o progresso, entre valores positivos e negativos e, o que não é menos delicado, entre as múltiplas vias que se lhe entreabrem sob o influxo de uma mesmíssima ordem de valores.

Inevitáveis, pois, as disputas, os conflitos, as crises, as guerras, a paz inquieta e aparente, assim como os períodos curtos ou longos de maior convergência entre o 'jurídico' e o 'político', enquanto fermentam novos estímulos para imprevistas exigências: nessa polaridade está todo o drama histórico do homem, que somente lograria fundir o Poder numa solução estática e definitiva se o esvaziasse de sua essencialidade histórica, se deixasse de ser a síntese original constitutiva de ser e dever ser."

(Miguel Reale, Teoria do Direito e do Estado, $4^{\mathrm{a}}$ ed., São Paulo, Saraiva, 1984, p. 381) 


\section{AGRADECIMENTOS}

Aos meus pais, por todo o apoio e carinho nessa trajetória. Sem vocês, nada disso seria possível.

Aos meus amigos de longa data, em especial, Fabio Bessa, João Gabriel Almeida, Gabriel Meirelles, Bruno Cravo, Renan Brandini e Ricardo Ferraris.

À minha namorada, Yasmin Moalla, por todo suporte emocional.

Aos amigos de Direito da PUC-Rio, em especial, Leonardo Werner, Vinicius Matera, Pedro Henrique Junqueira, Fabrizio Muzzo, Rayan Kiffer, Lucas Saldanha, Ramon Folhadela, Victor de Moraes, Pedro Henrique Bruno (Perox), Bernardo Barbosa, Bruno Fernandes, Bruno Cardoso, Ricardo Abreu, Mateus Camelier, Matheus Navega, Pedro Amaral, Carol Fernandes, Alexya Harfernist, Audrey Perondi, Mariana Fernandes, Florence Berrogain, Juliana Rabishoffsky, Thais Raposo, Gabriela Fernandes e Isadora Lewkovicz, que tenho como irmãos e irmãs, por todo o companheirismo e convivência nesses últimos 5 anos.

Ao time de tênis da Puc-Rio, que tive o prazer de integrar por esses 5 anos, em especial, Andre Buffara, Frederico Calmon e Guilherme Uchoa.

Aos companheiros de Colegiado da CVM, em especial, Ana Flávia Corrêa, Pedro Miranda Gomes e Pedro Maresguia. Certamente será difícil encontrar, ao longo de minha experiência profissional, outro lugar que concentre pessoas tão especiais como vocês. Sinto saudades não apenas das relevantes discussões sobre direito societário, mas também - e principalmente - da diária companhia de todos. 
Aos integrantes da equipe do ex-Diretor Roberto Tadeu Antunes Fernandes no Colegiado da CVM, em especial, Ary Costa Neto e Roberta Sultani, que tive o prazer e privilégio de integrar, pelos primeiros passos que dei no direito societário.

À Equipe de Direito Societário do BMA Advogados, em especial, Bruno Massena, Carolina Ferraz, Fernanda Pereira Nassif, Filipe Thompson, João Mello, Eduardo Bulhões, Matheus Barreto, Luisa Blasi, Marvio Bonelli, Tereza Mayrink Veiga, Renata Medina, Felipe Bon e Christopher Zibordi, pela enriquecedora convivência e ensinamentos diários.

Por último, ao meu mentor, chefe, professor e orientador Chico Müssnich, por todo o aprendizado, inspiração e debates travados em aula. 


\section{RESUMO}

MEDEIROS, Gabriel Ramalho. Uma análise sobre os mecanismos de dissociação do poder econômico e participação política nas companhias brasileiras. Rio de Janeiro: 2018: 119 p. Monografia de final de curso. Departamento de Direito da Pontifícia Universidade Católica do Rio de Janeiro - PUC-Rio.

A possibilidade de dissociar a participação econômica e a participação política nas sociedades anônimas foi anunciada pela primeira vez por Berle e Means em obra sobre o tema da governança corporativa. A questão suscitou uma série de debates no âmbito do direito societário e apresenta controvérsias até os dias de hoje. O presente trabalho vai analisar, a partir do histórico da estrutura de proprieade acionária brasileira, dois institutos que tem por finalidade a dissociação entre participação econômica e a participação política: as estruturas piramidais e as classes duais de ações. Dessa forma, este trabalho pretende verificar se, uma vez empregados, estes acabam se tornando práticas abusivas por parte do acionista controlador, ou devem ser analisados como (i) mecanismos legítimos para proteger o titular do poder de controle e (ii) alavancagem financeira da companhia. Ainda, será feita uma reflexão acerca do instituto do voto plural e do Projeto de Lei ${ }^{\circ}$ 10.736/2018.

Palavras-Chave: Estruturas de Propriedade; Poder de Controle Governança Corporativa - Novo Mercado - Direito de Voto - Conflito de Agência - Acionista Controlador - Acionista Minoritário - Administração - Alavancagem Financeira - Proporcionalidade - Mecanismos de Dissociação - Participação Econômica - Participação Política - Estruturas Piramidais - Classes Duais de Ações - Voto Plural. 
INTRODUÇÃO ..................................................................................................9

Capítulo 1 - Poder de Controle .....................................................................11

1.1. Conceito de Poder de Controle ........................................................ 11

1.2. Categorias de Poder de Controle .................................................. 12

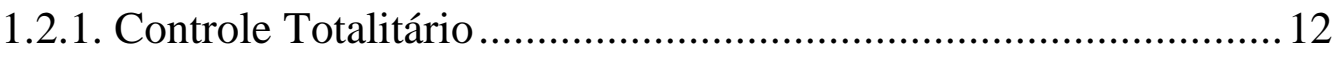

1.2.2. Controle Majoritário..................................................................... 13

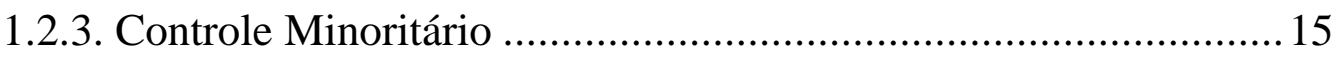

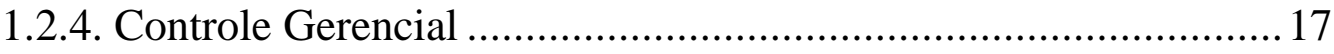

Capítulo 2 - Estruturas de Propriedade no Direito Comparado ............20

2.1. Regras Jurídicas como condicionantes da Estrutura Acionária .......20

2.1.1. Proteção aos acionistas em ambientes de concentração acionária 21

2.1.2. Proteção aos acionistas em ambientes de dispersão acionária .......22

2.2. Estrutura Acionária Americana .......................................................24

2.3. Estrutura Acionária Britânica …………………………………....28

Capítulo 3 - Estrutura de Propriedade das Companhias Brasileiras...35 Capítulo 4 - Mecanismos de Dissociação entre Participação Econômica e Participação Política .....................................................................................42

4.1. Estruturas Piramidais ....................................................................4 43

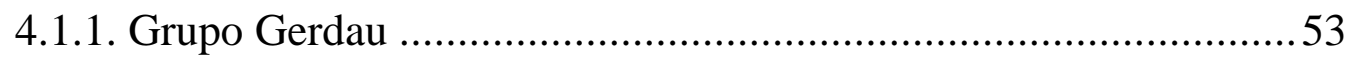

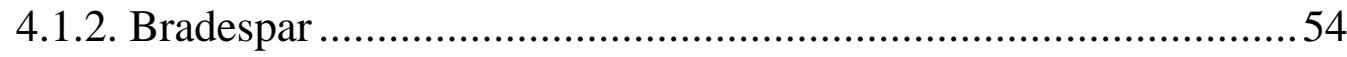

4.1.3. Estruturas Piramidais no Novo mercado .......................................56

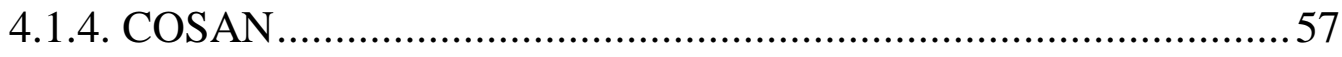

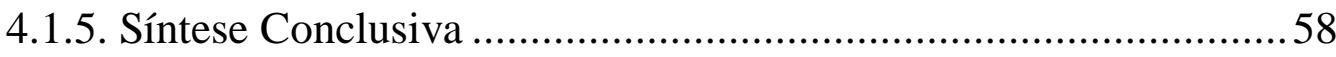

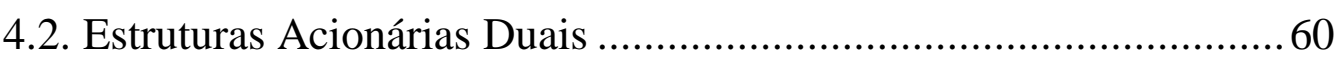

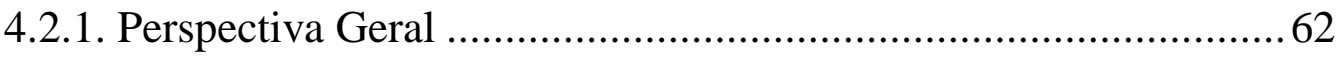

4.2.2. Voto Plural no Direito Comparado ...............................................63

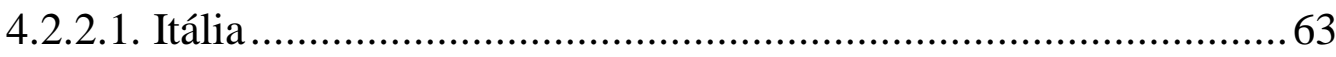

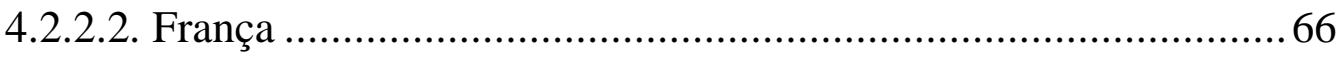




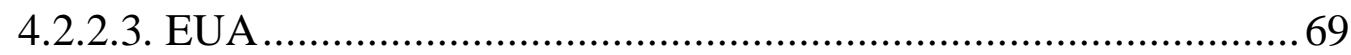

4.3. Emissão de Ações com Voto Plural em IPOs ..................................75

4.3.1. Casos Recentes (Google, Snapchat, Facebook e Alibaba).............75

4.3.2. Caso Snap Inc. ………………................................................... 79

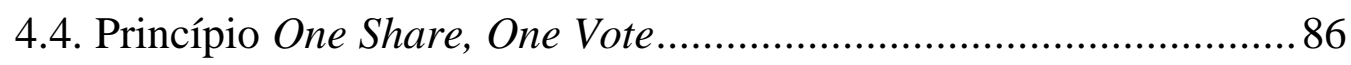

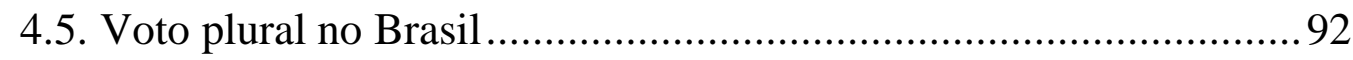

4.6. Projeto de Lei $\mathrm{n}^{\circ}$ 10.736/2018 (Anexo I) ……………………….....94

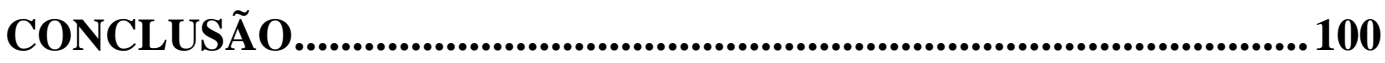

REFERÊNCIAS BIBLIOGRÁFICAS..........................................104

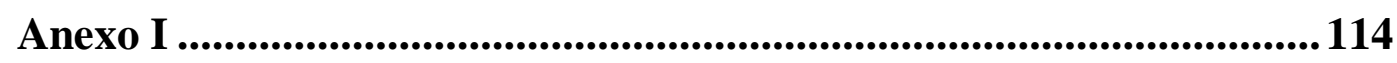

PROJETO DE LEI No 10.736, DE 2018 ............................................114

JUSTIFICAÇÃO …...................................................................116 


\section{LISTA DE FIGURAS}

Figura 1 ......................................................................................................51

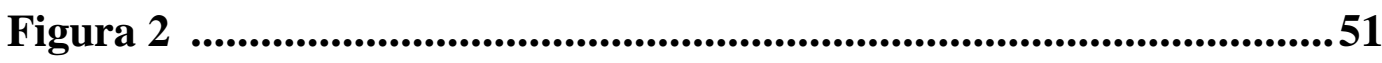

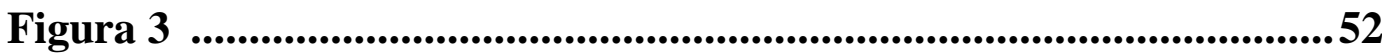

Figura 4 - ORGANOGRAMA GERDAU .................................................55

Figura 5 - ORGANOGRAMA BRADESPAR ........................................54

Figura 6 - ORGANOGRAMA COSAN ......................................................58

Figura 7 ................................................................................................... 70

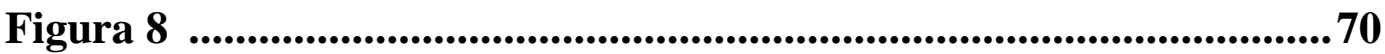




\section{INTRODUÇÃO}

O mercado de capitais brasileiro, nos últimos anos, vem sofrendo importantes transformações que influenciaram a estrutura de capital das companhias abertas e o poder de controle exercido por seus acionistas.

Ainda que recente, a dispersão acionária é uma realidade que vem se tornando mais evidente no mercado de capitais brasileiro. Esse fenômeno pôde ser observado com o advento de segmentos de maior governança corporativa, dentre os quais vale destacar o Novo Mercado, o qual em 2013 apresentou índices que se aproximam dos países com mercado de capitais desenvolvido como Estados Unidos, Inglaterra e Austrália, no que tange ao percentual de companhias sem acionistas controladores.

Ainda assim, o Brasil é um país que apresenta um histórico de elevada concentração do poder acionário, o que, segundo alguns autores, se dá em grande parte, pela existência de instrumentos jurídicos de dissociação entre representatividade política e participação econômica dos acionistas.

Este trabalho vai se debruçar na análise de dois mecanismos específicos de dissociação entre representatividade política e participação econômica dos acionistas. São eles: as estruturas piramidais de participação societária e as estruturas acionárias duais.

Em um primeiro momento, trataremos da análise do conceito de poder de controle e suas diversas modalidades para compreendermos como os acionistas, através desses mecanismos, exercem o poder de controle e como se conduz a relação entre os acionistas minoritários e os acionistas controladores.

Em seguida, analisaremos o surgimento dos segmentos de maior governança corporativa do mercado brasileiro e o histórico da estrutura de propriedade acionária brasileira. Além disso, se fará uma consideração com respeito ao tema no âmbito do direito comparado, a fim de 
compreendermos as condicionantes e a própria estrutura acionária de países com mercado de capitais desenvolvido, como os EUA e a Inglaterra.

Após essas considerações, discutiremos os conceitos e possíveis efeitos dos instrumentos jurídicos ora em análise. Nesse diapasão, o que se pretende verificar é se esses instrumentos, uma vez adotados pelas companhias, acabam por se tornar mecanismos de perpetuação do poder de controle por parte de alguns acionistas ou devem ser considerados instrumentos válidos e eficazes com respeito à captação de recursos e alavancagem econômica da companhia.

Por fim, em consequência da discussão apresentada, passaremos a analisar um tema específico: a possibilidade da adoção de ações com voto plural. O mundo atual, com a globalização, o acesso à informação e o surgimento de empresas de tecnologia, nos faz refletir acerca da aplicabilidade dessa regra jurídica no mercado de capitais, como mecanismo de capitalização e manutenção do poder de controle. Há inúmeros exemplos de legislações que permitem o voto plural, que serão objeto de estudo neste trabalho e de companhias que, a fim de ter um controle definido, estão migrando para esses países, em razão de uma legislação mais flexível e progressista frente ao mercado atual e o nível de governança corporativa. Será finalmente feita uma análise com o direito comparado e acerca do Projeto de Lei $\mathrm{n}^{\circ}$ 10.736/2018, em tramitação na Câmara dos Deputados, que visa instituir o voto plural no Brasil, acrescentando, portanto, o art. 110-A à Lei no 6.404/76, de modo a autorizar a atribuição do voto plural a uma única classe de ações e outras alterações pertinentes. 


\section{CAPÍTULO 1 - PODER DE CONTROLE}

Preliminarmente, cumpre destrinchar o conceito de poder de controle, que é objeto essencial para compreendermos os mecanismos aqui analisados. $\mathrm{O}$ objeto desse estudo tem como compreensão fundamental a correlação entre o exercício do direito de voto, ou seja, a participação política do acionista, e a participação econômica do acionista, que pode ser subentendida como o aporte de capital na companhia.

É nesse contexto que o conceito de poder de controle deve ser compreendido e os respectivos efeitos da utilização de mecanismos de dissociação entre a propriedade e o poder de comando empresarial analisados.

\subsection{Conceito de Poder de Controle}

A Companhia tem como órgão supremo a assembleia geral, que investe todos os demais órgãos e constitui a sua última instância decisória. É por meio dela que os acionistas, que constituem a maioria das ações com direito a voto, deliberam sobre qualquer matéria e, consequentemente, exercem o poder de controle.

A Lei $n^{\circ}$ 6.404/76 ("LSA') não define o significado de poder de controle, no entanto, em seu art. 116, traz o conceito de acionista controlador:

a pessoa, natural ou jurídica, ou o grupo de pessoas vinculadas por acordo de voto, ou sob controle comum que: a) é titular de direitos de sócio que lhe assegurem de modo permanente, a maioria dos votos nas deliberações da assembleia-geral e o poder de eleger a maioria dos administradores da companhia; e b) usa efetivamente seu poder para dirigir as atividades sociais e orientar o funcionamento dos órgãos da companhia.

Dessa forma, podemos entender que o acionista controlador só exerce o poder de controle de fato, quando este é titular de direito de sócios 
que lhe assegure de maneira permanente ${ }^{1}$ a maioria dos votos nas deliberações das assembleias gerais, podendo, para tanto, eleger a maioria dos administradores e, como resultado, usar esse poder para orientar efetivamente o controle diretivo das atividades empresariais e da vida da companhia. Nessa seara, torna-se fundamental constatar que o poder de controle é elemento extrinseco à propriedade das ações, sendo garantido por meio do exercício do direito de voto nas assembleias das companhias.

Definido o conceito de poder de controle, passamos agora a explanar as principais categorias de controle societário, dentre elas: (i) controle totalitário, (ii) controle majoritário, (iii) controle minoritário e (iv) controle gerencial.

\subsection{Categorias de Poder de Controle}

\subsubsection{Controle Totalitário}

A primeira categoria de poder de controle a se analisar é o controle totalitário, que se faz presente quando a totalidade de ações são de titularidade de um único acionista ou grupo de acionistas, vinculados por acordo de acionistas ${ }^{2}$. Nesse caso, não há aqui qualquer dissociação entre o poder político e a participação econômica, uma vez que a totalidade das ações se encontra na propriedade de um único acionista ou grupo de acionistas.

O controle totalitário é exercido quando o acionista ou grupo de acionistas, titular da totalidade das ações da companhia, participam das decisões assembleares e se manifestam por meio do voto a fim de fazer valer sua vontade na matéria a ser deliberada pela assembleia. Pode-se dizer

\footnotetext{
1 Regulamento do Novo Mercado (2017) "Poder de Controle" [...] Há presunção relativa de titularidade do controle em relação à pessoa ou ao Grupo de Acionistas que seja titular de ações que lhe tenham assegurado a maioria absoluta dos votos dos acionistas presentes nas 3 (três) últimas assembleias gerais da Companhia.

${ }^{2}$ Normalmente acordos de voto.
} 
que o controle totalitário é a categoria mais "estável" de poder de controle em comparação com as demais, uma vez que a prevalência nas assembleias gerais é assegurada, pois a totalidade das ações com direito a voto é de titularidade de um único acionista ou grupo de acionistas.

\subsubsection{Controle Majoritário}

Somente a partir do século XVIII que as Assembleias Gerais passaram a ser admitidas nas companhias e se tornaram um órgão importante no âmbito da tomada das decisões empresariais. Quando as sociedades anônimas se tornaram um instituto de direito privado, as legislações começaram a permitir a participação dos acionistas no processo decisório das companhias, e acabaram incorporando o conceito da sociedade democrática, mediante o exercício do direito de voto ${ }^{3}$. E por democracia devemos entender que as deliberações aprovadas no âmbito da companhia serão tomadas pela maioria, que se traduz como a parcela de ações suficientes para garantir, a um ou mais acionistas, a titularidade superior a 50\% das ações com direito a voto.

Nesse sentido, Lamy e Bulhões salientam que o "poder de controle é o poder supremo da estrutura hierárquica da companhia exercido pelo acionista controlador - titular da maioria pré-constituida dos votos na Assembleia Geral"4.

Cabe destacar que o histórico do mercado brasileiro tem como predominância o controle majoritário, estando esse poder, muitas vezes, nas mãos de grupos familiares e financeiros.

O princípio majoritário parte do princípio de que a sociedade anônima foi criada historicamente para permitir a constituição de um vasto corpo acionário. Nesse contexto, em companhias que contam com milhares

\footnotetext{
${ }^{3}$ A cada ação se confere um voto nas assembleias gerais.

${ }^{4}$ LAMY FILHO, Alfredo; PEDREIRA, José Luiz Bulhões (Coord.). Direito das companhias. $2^{\mathrm{a}}$ ed. atual. refor. Rio de Janeiro: GEN, Forense, 2017. p. 598.
} 
de acionistas, é incoerente acreditar na convergência de milhares de interesses para que se possa ter unanimidade nas deliberações sociais ${ }^{5}$. Assim sendo, nas principais legislações, estabeleceu-se o princípio majoritário para regular as sociedades por ações.

Esse princípio vem sendo desafiado, uma vez que a teoria institucionalista encontra-se utilizada com bastante frequência, inclusive no direito pátrio $^{6}$. Essa teoria, em contraponto à teoria contratualista, reconhece de forma crescente a convivência na sociedade de diversos interesses por ela afetados, não só os dos acionistas, como os dos empregados e a comunidade em que atua, por exemplo (stakeholders) ${ }^{7}$. Ao entendermos que a sociedade anônima converge e se constitui através de interesses diversos, é possível concluir que esse poder de controle, detido pela maioria dos acionistas com direito a voto, não é irrestrito e muito menos poderá servir para oprimir a minoria existente.

Aqui podemos citar alguns limites à atuação e responsabilidades do acionista controlador e também alguns dispositivos legais referentes à proteção da minoria, respectivamente: abuso de poder (art.117 LSA), dever de lealdade (art.116 e 155 LSA), unanimidade dos votos para aprovação de transformação da companhia (art.221 LSA), voto múltiplo para eleição de membro do conselho de administração (art.141 LSA), veto de minoritários por meio de acordo de acionistas (art.118 LSA), dentre outros.

Portanto, o controle majoritário, como já mencionado acima, verifica-se quando um acionista ou grupo de acionistas são proprietários de mais da metade das ações com direito a voto e, em consequência, utilizam

\footnotetext{
5 Salvo os casos que a lei exige unanimidade, como: transformação (art. 221 LSA), cisão desproporcional (art.229 LSA), aprovação de projeto do estatuto social (art.87, parágrafos LSA), dentre outros.

${ }^{6}$ Art.140 Parágrafo único. O estatuto poderá prever a participação no conselho de representantes dos empregados, escolhidos pelo voto destes, em eleição direta, organizada pela empresa, em conjunto com as entidades sindicais que os representem.

7 Termo utilizado para classificar os interessados no sucesso da companhia, podendo ser classificado no seguinte sentido: o stakeholder é uma pessoa ou um grupo, que justifica as ações de uma organização e que tem um papel direto ou indireto em sua gestão e seus resultados. Sendo assim, um stakeholder pode ser afetado positivamente ou negativamente, dependendo das suas políticas e forma de atuação.
} 
esse status para preponderar suas vontades nas deliberações em assembleias, com intuito de eleger a maioria dos administradores e orientar as atividades sociais da companhia.

\subsubsection{Controle Minoritário}

Existem situações, entretanto, nas quais um acionista ou grupo de acionistas é capaz de controlar a companhia sendo titular de menos da metade das ações votantes. Isso tornou-se possível em um cenário de grande pulverização das ações em circulação e com o fenômeno de absenteísmo nas assembleias gerais. Em regra, a companhia externaliza sua vontade por meio da deliberação dos acionistas em assembleia. Contudo, tendo em vista as razões mencionadas acima, nos deparamos com cenários em que um acionista ou grupo de acionistas, titulares de um bloco de ações inferior à maioria do capital social votante, consegue prevalecer nas deliberações assemblares e, portanto, controlar a companhia. É nessa hipótese que se dá o controle minoritário ${ }^{8}$.

Em linhas gerais, o controle minoritário pode ser compreendido como o poder de controle exercido por acionista que, apesar de não deter participação majoritária no capital social votante, consegue prevalecer nas assembleias gerais, orientar as atividades da companhia e eleger a maioria dos administradores 9 .

Nesse sentido:

\footnotetext{
${ }^{8}$ LAMY FILHO et al., 2017, p. 570.

Nas companhias com pequeno número de acionistas o controle permanente pressupõe maioria absoluta das ações, mas, na medida em que aumenta o grau de dispersão da propriedade das ações, pode ser exercido com menor porcentagem porque os não controladores em regra não comparecem às Assembleias Gerais; e há exemplos de grandes companhias controladas com 10\% ou menos do capital social. Nas companhias gigantes norte-americanas e europeias o grau de dispersão das ações chega ao ponto de os maiores acionistas possuírem, cada um, participação da ordem de $1 \%$ ou $2 \%$ do capital social.

${ }^{9}$ Esse fenômeno pode ser vislumbrado em um cenário de absenteísmo nas assembleias gerais e de formação de grupos de controle por meio de acordo de acionistas, ainda que não sejam titulares de participação majoritária no capital votante.
} 
No Brasil, a lei societária consagra o controle minoritário como princípio dentro do capital total da sociedade. A famosa regra que permitia a existência de até dois terços do capital total da empresa representados por ações preferenciais (sem voto) - art. $15, \S 2^{\circ}$, da Lei $\mathrm{n}^{\circ} 6.404 / 76$, agora reduzida a no máximo $50 \%$ do capital total - nada mais é que a consagração do controle minoritário. O sistema brasileiro pode, portanto, ser caracterizado como um sistema em que há opção clara pelo controle minoritário, no que respeita o capital total da companhia ${ }^{10}$.

Ora, o legislador brasileiro deixou claro seu posicionamento acerca do controle minoritário. Isto pode ser verificado na LSA, que determina os requisitos legais para que se caracterize a figura do acionista controlador: (i) titularidade de direitos de sócio que lhe assegurem maioria no capital votante de modo permanente; e (ii) o uso efetivo desse status para conduzir as atividades sociais e orientar o funcionamento dos demais órgãos da companhia. Ainda que o artigo 116 não exija um percentual mínimo de ações para identificar a figura do acionista controlador, a LSA admitiu implicitamente a existência de controle minoritário ${ }^{11}$.

Em linha com o exposto acima, o Regulamento do Novo Mercado de 2018 também incorporou a existência do controle minoritário ao criar elementos que auxiliam na configuração de acionista controlador, preservando os critérios tratados pela Resolução CMN n ${ }^{\circ} 401 / 1976^{12}$ (atualmente revogada), podendo ser observado na disposição que define o conceito de "controle" do próprio regulamento:

Para os fins desta seção, entende-se por controle e seus termos correlatos o poder efetivamente utilizado por acionista de dirigir as atividades sociais e orientar o funcionamento dos órgãos da companhia, de forma direta ou indireta, de fato ou

\footnotetext{
${ }^{10}$ COMPARATO, Fabio Konder; SALOMÃO FILHO, Calixto. Poder de Controle na Sociedade Anônima. $5^{\text {a }}$ ed. Rio de Janeiro: Ed. Forense, 2008. p. 68.

${ }^{11}$ EIZIRIK, Nelson. Aquisição de Controle Minoritário. Inexigibilidade de Oferta Pública In: Poder de Controle e outros Temas de Direito Societário e Mercado de Capitais. Quartier Latin, 2010. p. 180.

${ }^{12}$ Resolução $n^{\circ}$ 401/76: IV - Na companhia cujo controle é exercido por pessoa ou grupo de pessoas, que não é titular de ações que asseguram a maioria absoluta dos votos no capital social, considera-se acionista controlador, para os efeitos desta Resolução, a pessoa, ou grupo de pessoas vinculadas por acordo de acionistas, ou sob controle comum, que é titular de ações que lhe assegurem a maioria absoluta dos votos na três ultimas Assembleias Gerais da companhia.
} 
de direito, independentemente da participação acionária detida. ${ }^{13}$. (grifos meus)

\subsubsection{Controle Gerencial}

Por fim, temos o controle gerencial, o qual pode ser encontrado em situações onde o capital social se encontra pulverizado entre os acionistas e que, por consequência, não há a figura típica de um acionista controlador ou grupo de controle.

A esse fenômeno se deu o nome de Managerial Revolution (revolução gerencial), em que há o deslocamento do poder de controle para os administradores. Tal cenário é típico de empresas de grande porte, caracterizadas pelo elevado grau de organização normativa, estabilidade da estrutura e pela despersonalização dos valores mobiliários das companhias $^{14}$.

Essa modalidade de controle é definida por Berle e Means como management control $^{15}$ que, dada a extrema dispersão acionária, os administradores assumem o controle de fato, transformando-se em um órgão social que se autoperpetua. No mais, é um controle interno totalmente desvinculado da titularidade das ações que se divide o capital social. Segundo os mesmos autores, os administradores obtinham o controle por meio de mecanismos de representação de acionistas em assembleias (proxy machinery), explorando-se o fenômeno do absenteísmo do corpo acionário.

Nesse modelo, a reunião de um cenário com alta dispersão acionária com a inserção de regras estatuárias ${ }^{16}$ designadas a impedir a formação de

\footnotetext{
13 Regulamento do Novo Mercado de 2018. Disponível em: <http://www.bmfbovespa.com.br/pt_br/listagem/acoes/segmentos-de-listagem/novo-mercado/>. Acesso em: 04 nov. 2018.

${ }^{14}$ LAMY FILHO et al., 2017, p. 571.

15 A.A. Berle Jr.; G. Means. The Modern Corporation and Private Property. Nova Iorque: Ed. Revista, 1967. p. 78.

16 Vide: (i) obrigação de divulgação de aquisição acionaria, de modo que todo acionista ou grupo de acionistas que aumentar a sua participação em $1 \%$ do capital, por exemplo, deve comunicar tal fato à companhia e ao mercado; (ii) obrigatoriedade de realização de oferta pública pelo acionista ou grupo de acionista que adquire participação acionária superior a determinado percentual.
} 
uma maioria permanente resulta em que a direção efetiva seja executada pelos administradores em geral (diretoria e conselho de administração), no exercício legal de suas funções, uma vez que não há um bloco de ações que garanta a prevalência contínua do poder de controle.

Vale ressaltar aqui que a incidência de um cenário com dispersão acionária não é condição suficiente para caracterizar o controle gerencial. $\mathrm{O}$ controle gerencial é determinado pela ausência de um acionista controlador que disponha de direitos de sócios que assegurem sua predominância nas decisões e orientações da companhia. Portanto, faz-se necessário afirmar que o absenteísmo dos acionistas e a passividade para com a vida societária da companhia são elementos fundamentais para a configuração do controle gerencial. De outro modo, estaríamos diante de um controle detido por uma minoria ativista.

Esse cenário é encontrado, principalmente, em países cuja propriedade acionária é diluída, devido ao vasto corpo acionário e à ausência de um acionista controlador que predomina nas decisões empresariais. A maioria das grandes corporações em países como EUA e Inglaterra, onde o capital social se encontra diluído, acabam por ter os administradores atuando de maneira predominante na orientação das suas atividades. Todavia, o cenário brasileiro é completamente distinto, por ser um país em que há predominância de um controle concentrado.

Atualmente, a propriedade acionária brasileira vem se alterando de forma constante, podendo ser encontradas companhias com capital disperso, possibilitando alguns autores a afirmarem a existência de um controle gerencial em algumas delas. Por outro lado, outros autores entendem que o que ocorre no cenário brasileiro é a existência de companhias que apresentam uma base acionária dispersa, na qual alguns acionistas minoritários acabam informalmente se juntando e predominando nas decisões assembleares (de maneira transitória ou permanente). Contudo,

EIZIRIK, Nelson et al. Mercado de capitais - regime jurídico. $3^{\text {a }}$ ed. rev. e amp. Rio de Janeiro: Renovar, 2011. p. 398. 
isso é matéria bastante controversa na doutrina e não cabe a nós tomar, neste momento, partido de um lado ou de outro. 


\section{CAPÍtULO 2 - ESTRUTURAS DE PROPRIEDADE NO DIREITO COMPARADO}

\subsection{Regras Jurídicas como condicionantes da Estrutura Acionária}

Uma variedade de estudos demonstra que a maioria das companhias abertas de grande porte tem a presença de um acionista controlador - com exceção apenas dos EUA e do Reino Unido, onde o controle é exercido pelos administradores. A configuração desse panorama acerca da estrutura acionária de cada país se dá por uma série de fatores, dentre eles: jurídicos, políticos e regulatórios.

A estrutura acionária de determinado país é resultante, em grande parte, do arcabouço regulatório que permeia o tema e também das regras decorrentes da autorregulação. A soma dessas normas pode favorecer um sistema ou outro, como é o caso brasileiro, onde prevalece uma maior concentração das ações com direito a voto em um único acionista ou grupo de acionistas ou de países como EUA e Reino Unido, que apresentam uma maior dispersão no capital votante.

Por assim dizer, as normas - em sentido amplo - determinam padrões de propriedade acionária e estruturas de controle a serem adotados, no momento que em permitem a extração ilimitada de benefícios particulares decorrentes do controle ou admitem o emprego extensivo de mecanismos de dissociação entre propriedade acionária e o poder político.

É como sustentam Lucian A. Bebchuk e Mark J. Roe, in verbis:

(...) alguns países dispõem de normas de direito societário que incentivam estruturas de governança ou, mesmo até, impulsionam a sua adoção. Por exemplo, algumas dessas normas dizem respeito à composição do Board of Directors e ao grau de influência dos trabalhadores sobre a sociedade. Regras de autorregulação de Bolsa de Valores dos EUA e decisões de cortes estaduais militam em favor de uma maior proporção dos membros do Board independentes. Normas jurídicas do Japão levam à dominação de conselhos por membros não independentes. E normas na Alemanha determinam que representantes dos trabalhadores ocupem metade dos assentos no conselho de grandes companhias (...) em razão da importância das normas de direito societário, diferenças 
substanciais das mesmas entre diferentes países podem ser suficientes para dar ensejo a diferenças também substanciais dos padrões de propriedade acionária ${ }^{17}$.

\subsubsection{Proteção aos acionistas em ambientes de concentração acionária}

Pois bem, em companhias cujo capital acionário é mais concentrado e existe a figura de um acionista controlador ou grupo de controle, as normas que tutelam a proteção dos acionistas merecem uma atenção especial. Isso porque a figura do acionista controlador acarreta uma estabilidade nas decisões assembleares, sendo os minoritários meros seguidores da vontade dos controladores, por não conseguirem fazer valer suas vontades nas votações em assembleia.

Para tanto, nada adiantaria conferir proteção ao direito subjetivo de sócios, uma vez que a extensão dos direitos e deveres atribuídos a cada um, pode ser definida pela maioria, conforme tratamos no princípio majoritário. Portanto, cumpre destacar que a proteção da minoria e a tutela dos direitos de sócios são distintas, por se entender que a minoria - enquanto um grupo de acionistas com interesses convergentes - busca limitar o poder "ilimitado" de controle pelo controlador, impondo-lhe uma série de deveres, como o dever de diligência, dever de lealdade e a boa-fé, previstos nos arts. 153 e 155 da LSA $^{18}$ e art. $113^{19}$ do Código Civil. Esse conjunto de direitos

17 BEBCHUK, Lucian A; ROE, Mark J. A theory of Path Dependence in Corporate and Governance and Ownership. Columbia Law School: The Center for Law and Economics. Working Paper n. 131, 1999. cit p. 09.

${ }^{18}$ Art. 153. O administrador da companhia deve empregar, no exercício de suas funções, o cuidado e diligência que todo homem ativo e probo costuma empregar na administração dos seus próprios negócios.

Art. 155. O administrador deve servir com lealdade à companhia e manter reserva sobre os seus negócios, sendo-lhe vedado: I - usar, em benefício próprio ou de outrem, com ou sem prejuízo para a companhia, as oportunidades comerciais de que tenha conhecimento em razão do exercício de seu cargo; II - omitir-se no exercício ou proteção de direitos da companhia ou, visando à obtenção de vantagens, para si ou para outrem, deixar de aproveitar oportunidades de negócio de interesse da companhia; III - adquirir, para revender com lucro, bem ou direito que sabe necessário à companhia, ou que esta tencione adquirir. $\S 1^{\circ}$ Cumpre, ademais, ao administrador de companhia aberta, guardar sigilo sobre qualquer informação que ainda não tenha sido divulgada para conhecimento do mercado, obtida em razão do cargo e capaz de influir de modo ponderável na cotação de valores mobiliários, sendo-lhe vedado valer-se da informação para obter, para si ou para outrem, vantagem mediante compra ou venda de valores mobiliários. $\S 2^{\circ} \mathrm{O}$ administrador deve zelar para que a violação do disposto no $\S 1^{\circ}$ não possa ocorrer através de subordinados ou 
conferidos ao conjunto da minoria, pode, portanto, atrair acionistas para a vida societária da companhia, mesmo em cenários de concentração acionária, por restringirem a prática de atos abusivos por parte do controlador e lhe atribuirem deveres e responsabilidades.

\subsubsection{Proteção aos acionistas em ambientes de dispersão acionária}

Em circunstâncias opostas, ou seja, quando estamos diante de um cenário com companhias que não apresentam a figura de um acionista controlador e ostentam uma alta dispersão acionária, a proteção da minoria ganha menos relevância. Nesse caso, o poder de controle das atividades sociais das companhias passa a ser exercido pelos administradores (controle gerencial). Ora, do ponto de vista teórico, não haveria necessidade de atribuir certos direitos específicos para as minorias, uma vez que, diante da ausência de um acionista controlador, todos os acionistas conseguiriam, em regra, contribuir na formação da vontade coletiva. Ainda, não caberia atribuir deveres e responsabilidades a algumas minorias transitórias que prevalecem nas decisões assembleares.

No momento em que os administradores passam a exercer de fato o poder de controle das companhias, temos outro dilema. O conflito de interesses não se dá mais entre a figura do controlador e o minoritário. No âmbito da dispersão acionária, o administrador é responsável pelos rumos da atividade empresarial, sendo assim, os conflitos passam a ser entre os acionistas e os administradores ${ }^{20}$. É o que chamamos de "conflito de agência”.

\footnotetext{
terceiros de sua confiança. $\S 3^{\circ} \mathrm{A}$ pessoa prejudicada em compra e venda de valores mobiliários, contratada com infração do disposto nos $\S \S 1^{\circ}$ e $2^{\circ}$, tem direito de haver do infrator indenização por perdas e danos, a menos que ao contratar já conhecesse a informação. § $4^{\circ}$ É vedada a utilização de informação relevante ainda não divulgada, por qualquer pessoa que a ela tenha tido acesso, com a finalidade de auferir vantagem, para si ou para outrem, no mercado de valores mobiliários.

${ }^{19}$ Art. 113. Os negócios jurídicos devem ser interpretados conforme a boa-fé e os usos do lugar de sua celebração.

${ }^{20} \mathrm{O}$ aumento do número de companhias com o capital pulverizado em bolsa, notamos uma mudança gradativa, nestas companhias, do perfil do Conselho de Administração. De órgão formal,
} 
Segundo Jensen and Meckling ${ }^{21}$, a relação de agência no âmbito societário funciona como um contrato sob o qual um ou mais acionistas (principal), titulares de ações, contratam outra pessoa (o agente) para executar algum serviço em seu nome, que envolve delegação da gestão e a autoridade da tomada de decisão ao agente.

Partindo do princípio que ambas as partes da relação são maximizadores de lucro, podemos entender que o agente nem sempre atuará no melhor interesse do acionista. Por essa razão, o acionista pode limitar as divergências de seu interesse estabelecendo incentivos adequados para o agente e incorrer em custos de monitoramento destinados a limitar as suas atividades.

Além disso, em algumas situações, o acionista pagará ao agente para incorrer em custos (bonding costs) para garantir que ele não tomará certas decisões que prejudicariam o acionista ou para garantir que o acionista será compensado se ele tomar tais decisões ${ }^{22}$. No entanto, geralmente é impossível para o acionista ou o agente, a custo zero, garantir que o último tomará as decisões corretas. Na maioria das relações de agência, o acionista e o agente incorrerão em custos de monitoramento e de vinculação (pecuniários e não pecuniários) e, além disso, poderá ocorrer alguma divergência entre as decisões do agente e aquelas decisões que maximizariam o bem-estar do acionista ${ }^{23}$.

\footnotetext{
que se reunia esporadicamente para decidir conforme as orientações do acionista controlador, o Conselho de Administração passa a assumir as rédeas da administração e a impor a sua visão para os rumos da companhia. Na ausência de um único dono, o Conselho assume essa função, como representante dos acionistas, zelando pela condução dos negócios. SILVA, Carlos Alexandre Lobo e. A evolução da aquisição de controle de companhias abertas no Brasil. In: SILVA, Alexandre Couto (Coord.). Direito societário. São Paulo: Saraiva, 2013. p. 249.

${ }^{21}$ JENSEN, Michael C.; MECKLING, William H. Theory of the Firm: Managerial Behavior, Agency Costs and Ownership Structure. Journal of Financial Economics. October, 1976, v. 3, no 4, pp. 305-360.

${ }^{22}$ A teoria da agência tende a ver os gestores como estando sempre prontos a enganar os principais ou proprietários, a menos que sejam constantemente controlados. Os defensores do modelo do principal-agente, não afastam a possibilidade de ganhos para os accionistas, caso se proceda a uma melhoria da qualidade da governabilidade empresarial, e muitos apoiariam a introdução voluntária de um código (tal como o de Cadbury). ANTÓNIO, Nelson dos S. Estratégia Organizacional - Do Posicionamento ao Movimento. $2^{\mathrm{a}}$ ed. Lisboa: Edições Silabo, 2006. p. 123.

${ }^{23}$ JENSEN; MECKLING, 1976, p. 308.
} 
Os mesmos autores demonstram a origem do conflito entre acionistas e administradores, e entre os insiders (controladores acionistas que pertencem à administração) e outsiders (minoritários). Nesses casos, os insiders tomam as decisões em benefício próprio com relação aos outsiders $^{24}$. Ainda, definem que os custos de agência são a soma dos seguintes itens: (i) as despesas de monitoramento pelo acionista; (ii) os bonding costs pelo agente; e (iii) a perda residual pelo acionista.

Nesse sentido, reduzir o direito societário à mera garantia de direitos individuais pode não ser suficiente para uma adequada supervisão da atuação dos administradores da companhia, especialmente quando estes passam a exercer, de fato, o poder do controle societário ${ }^{25}$.

Do mesmo modo, quando, em razão da dispersão acionária, se forma um controle minoritário, ou seja, temos um bloco de controle minoritário, que passa a prevalecer de forma permanente nas decisões da companhia, por conta, muitas vezes, de mecanismos de dissociação entre o poder político e participação econômica, faz-se necessário atribuir aos acionistas não controladores uma proteção em decorrência desse poder de controle (ainda que transitório).

\subsection{Estrutura Acionária Americana}

A Bolsa de Valores de Nova Iorque foi fundada em 1792, no entanto, foi apenas a partir de 1862 que os EUA presenciou um processo de expansão no mercado de capitais, em virtude dos investimentos nas companhias ferroviárias e em grupos empresariais.

\footnotetext{
${ }^{24}$ SILVA, André Luiz Carvalhal da. A Influência da Estrutura de Controle e Propriedade no Valor, Estrutura de Capital e Política de Dividendos das Empresas Brasileiras. Rio de Janeiro, 2002. vii, 128 f.: il. Tese (Doutorado em Administração) - Universidade Federal do Rio de Janeiro - UFRJ, Instituto COPPEAD de Administração, 2002. p. 47.

25 AZEVEDO, Luís André N. de Moura. Controle Minoritário: Dissociação entre Voto e Participação Econômica na Companhia Aberta - Coleção IDSA de Direito Societário e Mercado de Capitais. v. 8. São Paulo: Quartier Latin, 2017. p. 60.
} 
Esse setor foi responsável por angariar os maiores investimentos e por criar os conglomerados industriais norte-americanos (ou "Trusts") 26 . Esse movimento se espalhou por toda América, e acabou originando os maiores grupos empresarias - praticamente todos monopolistas - como US. Steel, Standard Oil, American Cotton, National Biscuit, American Tabacco, General Eletric, International Harvester, AT\&T, United Fruit ${ }^{27}$.

Essas empresas utilizavam a Bolsa de Valores através do acesso à poupança popular, como instrumento de capitalização de recursos para financiar suas atividades, por meio de emissão de valores mobiliários. Muitas vezes esses recursos eram empregados para aquisição de outras companhias, o que gerou o aquecimento do mercado de fusões e aquisições, concentração empresarial e o desenvolvimento do mercado de capitais pós Primeira Guerra Mundial ${ }^{28}$.

Até a década de 1980, a criação de grupos empresariais em formato piramidal, assim como a possibilidade de emissão de ações com voto diferenciado (ou sem direito a voto) eram usuais. A tutela dos acionistas minoritários exigia que os próprios minoritários agissem de forma organizada a fim de pleitear com o controlador instrumentos de confiança e de condições mais favoráveis. A insuficiência de regras que tutelavam o direito dos minoritários, constituiu grande impeditivo para um ambiente com maior dispersão acionária e atratividade aos investidores.

\footnotetext{
${ }^{26} \mathrm{O}$ trust é o instrumento responsável por segregar a propriedade do bem de um lado, e o gestor e a posse de outro. SALOMÃO NETO, Eduardo. O trust no Direito Brasileiro. São Paulo: LTR, 1996.

O voting trust é constituído com a finalidade de reunir um trustee, mediante transferência fiduciária da propriedade das acoes, os direitos de voto que asseguram o controle de uma ou mais companhias. LAMY FILHO et al., 2017, p. 569.

${ }^{27}$ MICKLETWAIT, John; WOOLDRIDGE, Adrian. DUARTE, S. (trad.) A Companhia: Breve História de ma Ideia Revolucionária. Rio de Janeiro: Objetiva, 2003., p. 104.

${ }^{28}$ LAMY FILHO et al., 2017, p. 569.

Depois do Sherman Act, de 1980, que proibiu as práticas monopolistas, a concentração prosseguiu mediante fusões, incorporações e holding companies. O grande movimento de fusões e incorporações ocorreu entre 1897 e 1903, quando se formaram - para as indústrias e os serviços empresas com dimensão até então somente conhecida nas ferrovias. Nessa época criaram-se muitas das situações de mercado - que em geral perduram até hoje - em que a participação conjunta de duas, três ou quatro grandes empresas excede de 2/3 das vendas (cf. Mason, 1968, p. 399-400). Entre 1899 e 1904 ocorreram 2.500 fusões e incorporações, quase seis vezes o número observado no quatro anos anteriores.
} 
Em 1914 foi criada a Federal Trade Comission - FTC, primeiro órgão federal de combate a práticas anticompetitivas nos EUA, sendo resultado de esforços governamentais e da política conduzida pelo presidente americano à época Theodore Roosevelt, conhecida como "bust the trusts". Passo importante também foi dado com a criação do Federal Reserve - FED, responsável pela elaboração da política monetária e supervisão das demais instituições financeiras ${ }^{29}$.

Não obstante as iniciativas legislativas para com a regulação do mercado de capitais americano, este acabou pagando o preço com o colapso da Bolsa de Nova Iorque em 1929, o que deu início à Grande Depressão.

Em razão desse vácuo legislativo apresentado no cenário americano, duas leis entraram em vigor a partir dos anos 30: a Securities Act de 1933 e o Securities Exchange Act de 1934. A primeira tinha em seu escopo a proteção aos investidores, adotando o princípio do full disclosure, enquanto a segunda teve como objeto a criação da Securities Exchange Comission SEC $^{30}$ - agência reguladora responsável por disciplinar e fiscalizar o funcionamento do mercado de valores mobiliários. As duas leis pretenderam coibir condutas fraudulentas e ilícitas no mercado, assim como a transparência na divulgação de informações pelas companhias.

Além disso, podemos citar aqui a edição do Banking Act de 1933, que foi responsável por segregar as atividades dos bancos de investimentos dos bancos comerciais, dentre os quais estes estariam proibidos de: “( $i$ ) adquirir, por conta e ordem de seus correntistas, valores mobiliários de emissores não financeiros, (ii) adquirir participação societária, se afiliar ou compartilhar trabalhadores com companhias envolvidas nessas atividades" ${ }^{31}$.

\footnotetext{
${ }^{29}$ As atribuições estavam presentes no National Banking Acts de 1863 e 1864.

${ }^{30}$ Disponível em: <https://www.sec.gov/Article/whatwedo.html>. Acesso em: 06 out. 2018.

${ }^{31}$ AZEVEDO, 2017, p. 94.
} 
Ora, podemos observar, portanto, que as iniciativas legislativas aqui tratadas $^{32}$, se valeram, primordialmente, do combate à concentração do poder econômico e de ampliar o acesso ao mercado de valores mobiliários. Como bem sustentam Peter A. Gourevitch e James Shinn ${ }^{33}$ :

Contra o pano de fundo do Crash e da Grande Depressão, as coalizões políticas do New Deal, geraram um número significativo de novas leis e normas de regulação com profundas consequências de longo prazo para a governança corporativa nos EUA, incluindo (...) um significativo conjunto de normas de regulação e legais que acabaram por impedir a formação ou mesmo por dissolver o controle acionário, enquanto fortaleceram a proteção a investidores.

Além das iniciativas legislativas citadas, podemos destacar o papel da autorregulação ${ }^{34}$ no mercado de capitais que, muito presente no cenário americano, foi incorporado pelas leis federais, com objetivo de promover o desenvolvimento e dar mais eficiência ao mercado. Não obstante a SEC exerça o papel de agência reguladora, supervisionando as entidades de autorregulação, a atuação dessas é amparada e legitimada pelo Securities and Exchange Act, ao determinar a "promoção de princípios justos e equitativos" como meta a ser alcançada.

Nos anos 2000, com os escândalos contábeis ${ }^{35}$ amplamente divulgados no mercado americano, nasceu o Sarbanes-Oxley Act, o qual permitiu grandes alterações no arcabouço regulatório americano: (i) a auditoria passou a ser uma atividade diretamente controlada pela Public Company Accounting Oversight Board; (ii) o dever de diligência por parte dos administradores passou a ser regulado; (iii) criação de Comitê de Auditoria por parte de companhias listadas na bolsa; (iv) certificação das demonstrações financeiras pelo Diretor Financeiro e pelo Diretor Presidente

\footnotetext{
${ }^{32}$ Podemos destacar também: Trust Indenture Act, Investment Company Act, Employee Retirement Income Security Act - ERISA, Willians Act, Securities Exchange Act, dentre outros, que tiveram como escopo a limitação da atuação de alguns investidores de setores específicos, como os Fundos de Investimento, Fundos de Pensão e Seguradoras, determinando que esses não poderiam deter participação superior a determinada porcentagem de companhias, visando a diversificação no portfólio das companhias e dos próprios investidores.

${ }^{33}$ AZEVEDO, op. cit., p. 96.

${ }^{34}$ Exemplo de entidade autorreguladora: National Association of Stock Dealers - NASD

${ }^{35}$ Casos da Enron e da Wordlcom.
} 
das companhias; (v) supervisão e regulação da relação existente entre a administração e a empresa de auditoria ${ }^{36}$.

Os diplomas legais até aqui analisados foram essenciais para definir a estrutura de controle acionário predominante nos EUA nos dias atuais. Com efeito, esses limitaram à disponibilidade de alguns instrumentos que poderiam levar a um maior grau de concentração do poder acionário, como: a proibição de empréstimos entre as companhias e seus administradores e restrições aos mecanismos de remuneração variável de executivos. Ainda, (i) políticas públicas foram realizadas no intuito de diminuir a concentração do poder econômico e limitar os abusos de poder dentro das companhias abertas; e (ii) foram criados instrumentos para dar maior proteção aos acionistas minoritários, transparência na divulgação de informações e regulação dos conflitos de agência.

A reunião desses fatores, atrelada à atuação ativista dos investidores institucionais e de um conjunto de normas de atribuições decisórias aos administradores (management oriented model), foi decisivo para o modelo predominante na estrutura de propriedade americana, uma vez que, levou a um absenteísmo por parte dos acionistas, contribuindo para a prevalência dos administradores no controle das companhias americanas.

\subsection{Estrutura Acionária Britânica}

Apesar dos EUA serem também filiado à tradição inglesa do Common Law, eles o fazem com menor grau de liberalismo na regulação do mercado de capitais do que no Reino Unido, onde imperou a soft regulation, com maior propensão à formação de grandes conglomerados financeiros. Nos EUA, de forma distinta da Inglaterra, prosperou uma regulamentação mais intrusiva e com maior fragmentação das instituições financeiras.

\footnotetext{
${ }^{36}$ USP. Revista Contabilidade \& Finanças. São Paulo, v. 21, n. 52, jan./abr. 2010. p. 4.
} 
$\mathrm{Na}$ realidade, essa abordagem tem a ver com a estrutura sócio jurídica adotada pelos dois países, onde nos EUA impera o federalismo, por meio da descentralização de competências, típicas do federalismo norteamericano, de modo que as forças políticas locais prevaleçam na defesa de seus interesses particulares. No entanto, na arena política, a situação se inverte, havendo uma maior concentração política nos EUA através de seu bipartidarismo, em contraponto com pluralidade partidária no Reino Unido.

Em consequência de uma regulação mais branda e um menor grau de intervencionismo do Estado, o Reino Unido acabou por fomentar estruturas piramidais, principalmente, a partir de 1950, sendo, no entanto, revertido esse quadro com o aumento do controle hoje predominante no Reino Unido, caminhando para o surgimento da "New Corporation".

O desenvolvimento tardio de maior controle na regulação societária contribuiu para o crescimento de companhias com capital mais diversificado em detrimento da concentração anterior, onde prevalecia a presença de titulares da maioria das ações em circulação.

Para entendermos melhor esse processo precisamos passar pela evolução histórica da formação financeira no Reino Unido, a qual será exposta a seguir.

A regulação financeira no Reino Unido teve seu início em 1694 com a criação de um Banco Nacional para o controle da moeda, com o objetivo de financiar a coroa britânica e reconstruir a frota inglesa dizimada pelos franceses em 1690 na batalha de Bévéziers. Através de uma captação junto ao público com a emissão de títulos públicos na ordem de $£ 1.200 .000,00$ (valores da época), criou-se o The Governor and Company Bank of England.

Contudo, com o total descontrole de emissão de moedas, empréstimos a fundos perdidos, endividamento crescente e, em particular, o uso de reservas em ouro para financiar a guerra dos nove anos contra a França, fez-se necessário, em 1844, que a emissão de moedas estivesse 
atrelada a um metal precioso (ouro). Essa iniciativa deu origem ao chamado "padrão ouro", que foi, subsequentemente, adotado em todo o mundo. Nesse momento, o Banco da Inglaterra passou a ser o garantidor do sistema financeiro britânico, dando maior segurança aos agentes econômicos por boa parte do século XIX.

No que tange ao surgimento do mercado de capitais inglês, cumpre destacar o papel fundamental do desenvolvimento da revolução industrial, do aumento do consumo de produtos manufaturados e do crescimento dos centros urbanos. Assim, já em 1880, a Bolsa de Valores de Londres já tinha um valor transacional significativo para os padrões da época, diante de poucas exigências quanto à transparência para com os investidores ${ }^{37}$.

A partir de 1920, o Banco da Inglaterra passou a ter uma atuação de Banco Central regulador, sendo responsável pela edição de normas sobre o mercado financeiro e de capitais. Nesse contexto, com a crise de 1929, constatou-se que muitas instituições americanas transferiram suas sedes para o Reino Unido, em busca de ambientes de regulação mais seguros e propícios à atividade financeira.

Em 1931, o "Padrão Ouro" foi abandonado e substituído pela criação do Tesouro Nacional Britânico, mediante a realocação de reservas financeiras do Banco da Inglaterra, sendo esses recursos administrado por ele até os dias de hoje.

Nesse momento, o Banco da Inglaterra obteve maior autonomia na regulação do mercado financeiro e de capitais, inclusive, um papel preponderante na política monetária e na contenção das crises econômicas. No entanto, ainda persistindo um maior intervencionismo por parte da atividade reguladora, o Reino Unido se caracterizou ao longo dos anos pelo

\footnotetext{
${ }^{37}$ Nota-se um distanciamento dos Bancos junto às companhias listadas nos mercados americano e inglês. Os banqueiros exigiam um alto grau de segurança em seus empréstimos e, para manter a fidelidade e o respeito de seu grupo, pregavam a segurança financeira como sua principal bandeira, o que não ocorria no mercado de capitais.
} 
destaque de normas de autorregulação em paralelo àquelas derivadas dos órgãos reguladores.

Em 1986 foi editado o Financial Service Act - FSAct e a Securities and Investment Board - SIB ${ }^{38}$, responsáveis (i) pelas atribuições regulatórias do Banco da Inglaterra; e (ii) pela regulação do mercado de capitais, respectivamente. A criação da SIB, no entanto, apenas centralizou as normas existentes e não atuou efetivamente no sentido de dar maior segurança na regulação e no intervencionismo do mercado. Tal prática só pode ser observada após períodos de sucessivas crises econômicas, conforme serão expostas a seguir.

Em 1991, a primeira crise envolveu o BCCI (Bank of Credit and Commerce International), onde após intensas investigações, se constatou diversas fraudes contábeis de ocultação de valores, revelando um famoso relatório publicado pelo The Economist ${ }^{39}$, o qual abalou a credibilidade do Banco Central da Inglaterra. Ainda em 1991, podemos citar o escândalo da apropriação de valores dos fundos de pensão do grupo Mirror Group Newspapers pelo seu controlador Robert Maxwell.

O escândalo financeiro de maior evidência foi o do Barings, o mais antigo Banco de Investimento da Inglaterra, fundado em 1762, no qual obteve perdas de mais de $£ 800$ milhões em atividades de alto risco em operações de hedge, que foram feitos por operadores liderados por Nick Leeson $^{40}$.

Assim, em razão dos principais escândalos financeiros enunciados no mercado de capitais, o Chancellor of the Exchequer (Ministro da Fazenda) inglês decidiu unificar os órgãos de regulação e de autorregulação do mercado de capitais do Reino Unido. Com efeito, o Banco Central ficou

\footnotetext{
${ }^{38}$ Atuava em conjunto com o Panel on Takeovers and Mergers (1968).

${ }^{39}$ The Many Facades of BCCI. Revista The Economist. v. 320, $\mathrm{n}^{\circ}$ 7715, 13.07.1991.

${ }^{40}$ Nick Leeson foi preso por 6 anos e meio, outros dirigentes foram acusados e empresas de auditoria envolvidas, o que levou à quebra do banco em 1995.

KORNERT, Jan. The Barings Crises of 1890 and 1995: Causes, Courses, Consequences and the Danger of Domino Effects. In Journal of International Financial Markets, Institutions and Money, 13, nº 3, jul., 2003.
} 
responsável, exclusivamente, pela política monetária e fiscal e, a partir da SIB, em 1977, foi criado um órgão regulador, o Financial Services Authorities - FSA com a absorção de vários órgãos reguladores já existentes, como o Personal Investiment Authority - PIA, Investment Management Regulatory Organization - IMRO, Securities and Futures Authority - SFA, entre outros ${ }^{41}$.

Mais adiante, foi promulgado, em 2000, o FSMAct (Financial Services and Markets Act) o qual reconheceu o FSA como o único órgão regulador dos mercados financeiro e de capitais do Reino Unido ${ }^{42}$. O referido marco regulatório tinha por objetivos: (i) estabilidade do sistema financeiro, (ii) redução de crimes financeiros, (iii) manutenção da confiança do mercado de capitais e, ainda, como princípios de boa governança: (i) adoção da business judgement rule como parâmetro de responsabilização dos administradores, (ii) incentivo à inovação por parte das agências reguladoras e (iii) utilização dos recursos orçamentários de forma mais eficiente ${ }^{43}$.

Assim sendo, de forma distinta dos EUA, onde o sistema regulatório prioriza o correntista e o investidor ${ }^{44}$, o Reino Unido privilegiou a manutenção da confiança e da estabilidade do sistema financeiro e do mercado de capitais. Por essa razão, Londres permaneceu como um centro financeiro global, estimulando a inovação e a globalização.

Pois bem. A crise de 2008 nos leva a um outro dilema: teriam sido todos esses esforços legislativos insuficientes para a estabilidade do mercado britânico? Os ingleses entenderam que sim, uma vez que a regulação prevista no FSA não foi capaz de prever e evitar os danos causados pela crise, principalmente no setor financeiro e imobiliário, que

\footnotetext{
${ }^{41}$ AZEVEDO, 2017, p. 117.

${ }^{42}$ FERRAN, Eilis. Examining the United Kindom's Experience in Adopting the Single Financial Regulator Model. In: n. 28 Brooklin Journal of International Law, 2003. p. 280-284. Disponível em: <http://brooklynworks.brooklaw.edu/bjil/vol28/iss2/2>. Acesso em: 25 out.2018.

43 AZEVEDO, op. cit., p. 118.

${ }^{44}$ Ibid., p. 119.
} 
anunciou a quebra de diversas empresas do ramo e sério desemprego do setor.

Em resposta à crise, em março de 2009, foi divulgado o Turner Review $^{45}$, o qual reconheceu que a soft regulation não obteve o resultado esperado nas medidas para solucionar a crise e passou a exigir uma nova série de normas, instituindo parâmetros de conduta e de fiscalização das instituições financeiras.

Diante do abalo reputacional, a imagem da FSA sucumbiu. Nesse contexto, foi criado o Financial Services Act, responsável pela repartição das atribuições regulatórias, ficando a par do Banco da Inglaterra e de duas novas agências: A Prudential Regulation Authority e a Financial Conduct Authority.

São distintos os caminhos que conduziram a dispersão do capital nas companhias abertas dos EUA e do Reino Unido, mas de forma geral, ocorreram no início do século XX, notadamente em 1900, 1920, 1930, dos quais originaram os grandes grupos econômicos de hoje.

No primeiro momento, as operações societárias se realizavam de forma consensual, enquanto a partir de 1950, o mercado passou a vivenciar operações de tomadas hostis de controle (hostile takeover). A partir desse panorama, foi introduzido uma série de normas jurídicas, conforme destacado anteriormente, garantindo maior transparência das operações e transações ao público investidor. Várias medidas anti takeovers foram reguladas, como (i) as limitações do direito de voto a partir de uma determinada participação societária, (ii) adoção de estruturas piramidais por meio de interposição de sociedades holdings em cadeia vertical, (iii) realização de oferta pública de aquisição de ações quando o acionista

\footnotetext{
${ }^{45}$ TURNER, Jonathan A. The Turner Review, A Regulatory Response to the Global Banking Crisis. S.l.: s.n., mar., 2009. Disponível em:〈http://fsa.gov.uk/pubs/other/turner_review.pdf>. Acesso em: 06 out. 2018.
} 
tivesse uma participação superior a 30\%, dentre outras, a fim de garantir proteção ao investidor minoritário ${ }^{46}$.

A autorregulação e os elevados padrões de ética da sociedade inglesa também foram fundamentais na contribuição para um ambiente de maior dispersão do capital no mercado de capitais do Reino Unido, com a ampla presença de investidores institucionais e um efetivo regime jurídico de proteção de minorias.

As sanções de ordem reputacional e a possibilidade de perdas de negócios eram ameaças constantes ao mercado, contribuindo para que houvessem iniciativas com o objetivo de dar maior segurança jurídica e transparência, aliados à tradição histórica de autorregulação e servindo de parâmetro para investidores na Europa e no resto do mundo.

\footnotetext{
${ }^{46}$ Inclusive a própria criação do Panel on Take Overs and Mergers surgiu com objetivo de punir
} os abusos e excessos. 


\section{CAPÍtULO 3 - ESTRUTURA DE PROPRIEDADE DAS COMPANHIAS BRASILEIRAS}

Historicamente, a estrutura acionária brasileira foi definida pela alta concentração do poder acionário. Isso pode ser vislumbrado desde o século XIX, no estatuto social do Banco do Brasil, em que a convocação da assembleia geral só poderia ser feita pelos 40 maiores acionistas portugueses, constatando-se claramente uma distinção entre os acionistas titulares do poder de controle e os demais investidores.

Em 1976, com a criação da LSA e da Lei nº 6.385 demonstrou-se interesse para estimular a captação de recursos das companhias através do mercado de capitais, entretanto, ainda preservando o caráter familiar e concentrado da estrutura acionária brasileira.

Nelson Eizirik, em "o mito do controle gerencial - alguns dados empíricos", descontrói a tese de Berle e Means acerca da dissociação entre a propriedade e controle, entendendo que não seria aplicável à realidade das companhias brasileiras, como segue:

[...] o conceito de Cia. Aberta pouco ou nada tem a ver com a efetiva 'abertura' (no sentido de democratização) do seu capital votante. Este permanece nas mãos do acionista controlador, no qual concentra-se o poder diretivo da companhia. A chamada 'revolução dos gerentes' - tese visando demonstrar superioridade de um sistema que promoveria, privadamente, a progressiva 'socialização' dos meios de produção pela via da dispersão acionária - entre nós não vingou ${ }^{47}$.

O estudo mais abrangente que pode demonstrar a realidade brasileira (à época), foi realizado por Dante Aldrighi e Roberto Mazzer Neto ${ }^{48}$, o qual teve como base o período entre 1997 e 2002. Nesse estudo, os autores verificaram ampla incidência de companhias com controle definido: (i)

\footnotetext{
${ }^{47}$ EIZIRIK, Nelson. O Mito do "Controle Gerencial": Alguns Dados Empíricos. Revista de Direito Mercantil Industrial, Econômico e Financeiro, São Paulo, ano XXVI, nº 66, pp. 103-106, Abr/Jun. 1987.

48 ALDRIGHI, Dante M.; MAZZER NETO, Roberto. Evidências sobre as Estruturas de Propriedade de Capital e de Voto das Empresas de Capital Aberto no Brasil. Revista Brasileira de Economia, vol. 61, n.2, Rio de Janeiro abril/junho, 2007. p. 137.
} 
familiar $(54,7 \%)$, (ii) capital estrangeiro $(18,4 \%)$, (iii) estatal $(5,7 \%)$, (iv) fundos de investimentos $(5,2 \%)$ e (v) fundos de pensão $(2,0 \%)$. Apontaram ainda, que $77,6 \%$ das companhias tinha um acionista controlador definido e que em $47,9 \%$ o controlador era titular da maioria do capital votante. Dante Aldrighi e Roberto Mazzer Neto concluem que uma estrutura que contenha maior acionista controlador concentra na média mais de $51 \%$ do capital e quase $73 \%$ dos votos ${ }^{4950}$.

Com efeito, os estudos empíricos supracitados demonstraram que as reformas legislativas e a autorregulação não produziram modificações no quadro de elevadas concentrações acionárias, em razão do uso difundido de mecanismos de dissociação entre propriedade e poder de controle.

Em razão de fatores histórico-econômicos, como (i) o surgimento do Plano Real; (ii) os processos de privatizações; (iii) a reforma da LSA com fortalecimento dos direitos dos minoritários oriundos da Lei $\mathrm{n}^{\mathbf{0}}$ 10.303/01; (iv) boom de IPOs nos anos de 2006 e 2007; e (v) a criação de novos segmentos de governança corporativa, esse cenário tem apresentado mudanças graduais conforme se verificará a seguir.

Até os anos 2000, o mercado de capitais brasileiro não representava uma forma de financiamento muito utilizado pelas companhias e visto de forma atraente aos investidores. Não obstante tenham sido os esforços para estimular o crescimento do mercado de capitais, transformar-se em uma fonte de recursos das empresas para se financiar estava muito distante da realidade.

\footnotetext{
${ }^{49}$ Segundo os autores, o grau de concentração da estrutura acionária apresentado poderia ser prejudicial para o desenvolvimento e fortalecimento dos mercados primários e secundáros.

${ }_{50}$ Ainda, em 2012, os mesmos autores assentaram que em mais de 1/3 das companhias abertas, integrantes de estruturas piramidais, detinham mais de $50 \%$ do capital social. Nessas companhias, diante da alta participação no capital social pelo controlador, a dissociação ente voto e participação econômica tenderia a ser menos expressiva. No entanto, uma quantidade próxima de $38 \%$ de companhias abertas apresentava, no mesmo período, ações preferenciais sem direito a voto representativas de mais da metade do capital social, o que indica, nesse caso, situação exatamente oposta, tendente, portanto, a uma maior concentração do poder de controle. ALDRIGHI; MAZZER NETO, 2007, p. 148.
} 
No final dos anos 2000, a Bolsa de Valores de São Paulo, atual B3 ${ }^{51}$, criou três segmentos especiais de listagem em ordem crescente de critérios de governança corporativa: Nível 1, Nível 2 e o Novo Mercado.

Esses novos segmentos de listagem, em especial o Novo Mercado, têm como origem a iniciativa da Organisation for Economic Coperation and Development $(\mathrm{OECD})^{52} \mathrm{e}$ da International Finance Corporation (IFC), que com o objetivo de incentivar o desenvolvimento do mercados de capitais, se reuniu para realizar Mesas Redondas de governança corporativa ao redor do mundo.

Essa reunião propunha-se, primordialmente, aos formuladores de políticas públicas, entidades reguladoras e autorreguladoras, a fim de debater perspectivas de política pública de governança corporativa. A primeira mesa redonda na América latina foi realizada no mês abril de 2000, sediada na cidade de São Paulo, a qual resultou o documento "Synthesis Note" e posteriormente o "White Paper on Corporate Governance in Latin America". O debate se baseou em uma série de dados empíricos considerando as normas regulatórias, as estruturas de governança corporativa e de propriedade acionária da região.

Vale ressaltar que o mercado de capitais dos países participantes tinha como características predominantes: (i) propriedade concentrada das companhias listadas; (ii) limitação dos mercados de capitais domésticos e baixa liquidez das ações; (iii) existência de grandes companhias

\footnotetext{
${ }^{51}$ A B3 foi criada em março de 2017 a partir da combinação de atividades da BM\&FBOVESPA, bolsa de valores, mercadorias e futuros, com a CETIP, empresa prestadora de serviços financeiros no mercado de balcão organizado. Essa combinação consolidou a atuação da Companhia como provedora de infraestrutura para o mercado financeiro, permitindo a ampliação do leque de serviços e produtos oferecidos aos seus clientes e a criação de eficiências para a Companhia e para o mercado. Disponível em: <http://ri.bmfbovespa.com.br/static/ptb/perfil-

historico.asp?idioma=ptb>. Acesso em: 26 out. 2018.

${ }^{52}$ A OECD tem como objetivo principal a disseminação e a fomentação de boas práticas de governança corporativa, além de consituir acordos entre os principais agentes de mercado.
} 
recentemente privatizadas; (iv) utilização de ações sem direito a voto, entre outros $^{53}$.

Com intuito de corroborar os questionamentos sobre as práticas desses países e depois de diversos debates travados sobre o assunto, a pesquisa apresentou resultado no sentido de que o tema considerado como prioritário para os investidores estrangeiros, era o "direito dos investidores", e para os investidores locais a "prestação de contas". Assim sendo, a OCDE e a IFC, ao diagnosticarem os problemas dos mercados em desenvolvimento, produziram uma serie de documentos oficiais que analisaram a relação da proteção aos investidores e o grau de desenvolvimento do mercado local.

Nesse contexto:

Especificamente, La Porta et al (1998) construíram um indicador aplicado a 49 países com o objetivo de avaliar a legislação de cada um referente à proteção de investidores e credores, a origem legal dessa legislação e a qualidade da execução dessas normas (enforcement). $\mathrm{O}$ estudo concluiu que havia uma relação de causalidade entre a existência de certas normas de proteção ao investidor e o tipo de financiamento predominante das companhias.

\section{$[\ldots]$}

Esse entendimento confunde sintomas e causas fazendo com que La Porta et al (1998) afirmem que a qualidade da proteção aos investidores determina a concentração de propriedade quando parece ocorrer exatamente o oposto: uma maior proteção aos investidores é o que estimula a maior dispersão do capital das companhias $^{54}$.

Esses estudos foram objeto de diversas críticas, as quais não convém se debruçar neste trabalho, apesar de terem sido constantemente utilizados pelo Banco Mundial. De certa forma, a implementação de regras de proteção ao investidor continuou sendo considerada como um caminho a ser seguido para o desenvolvimento do mercado de capitais.

${ }^{53}$ DANAGGIO, Angela Rita Franco. Governança Corporativa e novo mercado: proteção ao investidor e falhas no marco regulatório. São Paulo: Ed. Saraiva, 2012. p. 44.

${ }^{54}$ Ibid., p. 48. 
Diante do panorama apresentado, no Brasil, de 1996 a 2000, o número de companhias listadas na bolsa de valores diminuiu em 110 e o volume negociado caiu em $\mathrm{R} \$ 110$ bilhões de 1997 a $2000^{55}$. Com efeito, a Bovespa com a finalidade de alterar esse cenário, elaborou um estudo para diagnosticar as falhas no mercado brasileiro para atrair novos investidores, tendo como resultado as seguintes sugestões: (i) adoção de arbitragem na resolução de conflitos; (ii) criação de segmentos de maior governança corporativa; (iii) apoio aos conselheiros independentes; e (iv) redução de custos de transação.

A partir desse cenário, algumas iniciativas legislativas brasileiras merecem destaque ${ }^{56}$ :

(i) edição do Código do Instituto Brasileiro de Governança Corporativa - IBGC (1999), incorporando algumas das recomendações da OCDE sobre práticas equitativas de gestão empresarial;

(ii) reforma da LSA e da Lei $\mathrm{n}^{\circ} 6.385 / 76$, que conferiu uma ampla proteção aos minoritários e deu maior autonomia à Comissão de Valores Mobiliários ("CVM") em suas competências regulatórias e fiscalizatórias; e

(iii) criação, pela Bolsa de Valores de São Paulo, de segmentos especiais de governança, já aqui destacados, como Nível 1, Nível 2 e Novo Mercado.

$\mathrm{O}$ crescimento de movimentos em prol da proteção aos investidores e de melhores práticas de governança corporativa, questionou algumas normas previstas na LSA, dentre as quais possibilitavam uma maior concentração do poder acionário, por exemplo: (i) possibilidade de emissão de ações preferenciais sem direito a voto e (ii) possibilidade de exercer o poder de controle por meio de estruturas piramidais.

\footnotetext{
${ }^{55}$ DANAGGIO, 2012, p. 51.
}

${ }^{56}$ AZEVEDO, 2017, p. 30. 
Foi somente com o advento do Novo Mercado, segmento de mais alta governança corporativa da B3, e o boom de aberturas de capital na década de 2000, que algumas companhias passaram a apresentar uma maior dispersão acionária ${ }^{57}$.

Constatado o histórico de concentração acionária, a tentativa do legislador se deu através do rearranjo das relações de poder da companhia, com o fortalecimento dos direitos dos minoritários. O segmento do Novo Mercado comprova isso ao analisarmos algumas de suas regras, como: (i) imposição de todas as ações terem direito a voto; (ii) $20 \%$ dos assentos do conselho de administração da companhia devem ser ocupados por conselheiros independentes; (iii) em caso de oferta pública de aquisição de ações, o adquirente deverá ofertar aos demais acionistas pelo mesmo preço pago ao controlador (tag along); e (iv) $25 \%$ do capital social devem estar em circulação na Bolsa (free float $)^{58}$. Tais regras acabam dificultando a adoção de medidas que dissociem a propriedade acionária da participação política na companhia. Logo, a partir da adoção dessas medidas, pôde se constatar um aumento de companhias cuja pulverização e dispersão acionária haviam aumentado.

Sob essa perspectiva, é válido citar Gorga ${ }^{59}$, que tomou como base informações de companhias abertas nos anos de 2006 e 2007 - período de alto crescimento do mercado de valores mobiliários brasileiro - e revelou que das 92 companhias integrantes do Novo Mercado, 45 não possuíam controlador $^{60}$.

\footnotetext{
57 Exemplos: (i) Br Malls Participações S.A. apresenta 69,1\% de suas ações no free float. Disponível em: <http://ri.brmalls.com.br/conteudo_pt.asp?idioma=0\&conta=28\&tipo=50854> . Acesso em: 03.11.2018.

(ii) Vale S.A. apresenta 58,9\% de suas ações no free float.

Disponível em: <http://www.vale.com/brasil/PT/investors/company/shareholdingstructure/Paginas/default.aspx>. Acesso em: 03.11.2018.

${ }^{58}$ Regulamento do Novo Mercado 2018.

${ }^{59}$ GORGA, Érica R. Changing the Paradigm of Stock Ownership from Concentrated Towards Dispersed Ownership? Evidence from Brazil and Consequences for Emerging Countries. Cornell Law School Working Papers, set., 2008. p. 90.

${ }^{60}$ Em setembro de 2014, o Novo Mercado contava com 62 companhias com controle minoritário. PUC-Rio. Departamento de Direito. Direito Empresarial Estudos Contemporâneos. Grupo de
} 
Entretanto, a autora alerta para o fato de que seu estudo não levou em consideração os acordos de acionistas voltados para a manutenção do poder de controle. A partir do momento em que se levou em consideração tais acordos, o resultado foi completamente distinto. Das 92 companhias listadas no Novo Mercado, 51\% tinham um acionista controlador definido. Portanto, nota-se que o histórico brasileiro de concentração acionária continua representando a realidade da maioria das companhias abertas brasileiras. Finalmente, segundo a autora, não se pode negar que o Novo Mercado apresentou um avanço nesse sentido, todavia, não cabe sustentar que ocorreu uma mudança significativa da estrutura de propriedade acionária no Brasil.

Além disso, a KPMG, em 2013, divulgou estudo sobre governança corporativa no Brasil ${ }^{61}$ e analisou 129 companhias listadas no Novo Mercado. O resultado da pesquisa demonstrou o seguinte cenário da estrutura de propriedade nas companhias brasileiras: controle (i) compartilhado (47\%), estatal (26\%), estrangeiro (17\%), familiar (7\%) e pulverizado $(3 \%)$.

Diante da conjuntura geral presente no mercado de capitais brasileiro, conclui-se que, apesar da dispersão acionária encontrada nesse segmento específico, as companhias sem controlador definido ainda são em número reduzido, em comparação com os EUA e o Reino Unido, onde a dispersão acionária é predominante na maioria das companhias.

Direito Empresarial da PUC-Rio, Ed. Quartier Latin. CRISTÓFARO, Pedro Paulo; MACHADO FILHO, Caio (Coord.). 2017. p. 217.

${ }^{61}$ Disponível em:

<http://construcaomercado17.pini.com.br/downloads/a_governanca_corporativa_e_o_mercado_de _capitais_13_14.pdf>. Acesso em: 26 out. 2018. 


\section{CAPÍTULO 4 - MECANISMOS DE DISSOCIAÇÃO ENTRE PARTICIPAÇÃO ECONÔMICA E PARTICIPAÇÃO POLÍTICA}

Um dos fenômenos básicos da sociedade anônima moderna, conforme sustenta Berle e Means ${ }^{62}$, tendo como base os dados estatísticos de 1929, é a possibilidade de dissociação entre a propriedade acionária e poder de comando empresarial.

Os mecanismos como as estruturas piramidais e as classes duais de ações são utilizados com o objetivo de dissociar a propriedade e o controle. É por meio deles que o acionista controlador passa a prevalecer nas deliberações assembleares, embora detenha participação reduzida no capital social. Tais mecanismos podem apresentar algumas distorções, uma vez adotados de forma a garantir a manutenção do poder de controle nas mãos de uma parcela pequena dos acionistas.

A LSA prevê no parágrafo primeiro do art.115 a possibilidade do acionista controlador auferir vantagens para si, proibindo-o, dessa forma, de votar: "em deliberações da assembleia-geral relativas ao laudo de avaliação de bens com que concorrer para a formação do capital social e à aprovação de suas contas como administrador, nem em quaisquer outras que puderem beneficiá-lo de modo particular, ou em que tiver interesse conflitante com o da companhia"63.

As pesquisas sobre estrutura de propriedade, desvios de direitos e seus mecanismos é extensa; todavia, não há consenso de seus impactos sobre o valor e desempenho econômico das companhias ${ }^{64}$.

\footnotetext{
62 A.A.; G. Means, 1967, p. 67.

63 Art. $115, \S 1^{\circ}$, da LSA.

${ }^{64}$ DEMSETZ, H.; LEHN, K. The Structure of Corporate Ownership: Causes and Consequences. The Journal of Political Economy. 1985. Disponível em: <http://dx.doi.org/10.1086/261354>. Acesso em: 04 nov. 2018.

Id., VILLALONGA, B. Ownership structure and corporate performance. Journal of Corporate Finance. 2001. Disponível em: 〈http://dx.doi.org/10.1016/S0929-1199(01)00020-7>. Acesso em: 04 nov. 2018.
} 
Os instrumentos jurídicos que modificam os direitos conferidos a cada classe de ação dependem, e muito, do modo de alocação e de titularidade do poder de controle. Assim, alguns mecanismos são mais efetivos em companhias com acionista controlador e em outras situações se adaptam melhor com o administrador controlador. Não obstante, os mecanismos compatíveis em ambas estruturas vão ter efeitos diversos dependendo da forma como serão exercidos.

A análise desse tema leva principalmente à compreensão de duas estruturas jurídicas objeto de estudo no presente trabalho: as estruturas piramidais e as estruturas duais, sendo esta última, objeto de reflexão para possível alteração legislativa.

\subsection{Estruturas Piramidais}

As estruturas piramidais, bem como as estruturas de classes duais, desviam do princípio consolidado no art. 110 da LSA, que é o princípio "one share, one vote", o qual será objeto de análise em momento posterior. As estruturas piramidais são mecanismos utilizados pelas companhias com objetivo de alavancagem financeira, a fim de permitir o controle acionário por parte do acionista controlador, de forma que este incorra em investimento reduzido no capital das companhias investidas. Obviamente são mecanismos que reduzem a proporção entre o poder de controle e a propriedade. É o que afirma Berle e Means ${ }^{65}$ :

A estrutura piramidal envolve a propriedade da participação majoritária no capital de uma companhia que, por sua vez, detém a maioria do capital de outra, em um processo que pode ser repetido inúmeras vezes. Assim uma participação igual a ou pouco inferior a um quarto, um oitavo, um dezesseis avos ou menos que isso e por meio dessa metodologia 'entrincheirada'. (...) O detentor da maioria do capital da companhia no topo da pirâmide pode exercer o controle total das companhias (...) não obstante sua participação seja até mesmo inferior a um por cento do total.

HIMMELBERG, C.P.; HUBBARD, R.G.; PALIA, D. Understanding the determinants of managerial ownership and the link between ownership and performance. Journal of Financial Economics, 53: 1999. p. 353-384.

65 A.A.; G. Means, 1967, p. 72-73. 
Consoante o abordado anteriormente em relação às medidas legislativas de atração ao mercado de capitais, uma delas foi a criação do código do Instituto Brasileiro de Governança Corporativa (IBGC). O código teve por objetivo orientar as companhias brasileiras na adoção das melhores práticas de governança, como: (i) a prestação de contas, (ii) a transparência e (iii) a equidade. Uma de suas regras é a que o princípio "one share, one vote" deve ser valorizado pelas companhias que tenham por objetivo abrir o capital, visando atribuir direitos de voto para todos os acionistas e seguir com a proporcionalidade entre o poder de controle e o capital investido. Entretanto, a LSA excepciona a adoção desse princípio por diversas vezes, permitindo a adoção de mecanismos que desviam desse padrão estatutário, como a possibilidade de emissão de ações preferenciais sem direito a voto. Entre os mecanismos utilizados para alcançar a dissociação entre propriedade e controle estão: estruturas piramidais, emissão de ações sem direito a votos, acordo de acionistas (de controle), estrutura de participações recíprocas, entre outros.

Segundo Hallqvist ${ }^{66}$, a governança corporativa tem por objetivo os seguintes itens: (i) tratamento equitativo entre os acionistas, (ii) transparência das estruturas e das operações da companhia e (iii) cobrança de responsabilidade consoante à atuação dos órgãos da administração.

A reforma da LSA e a criação do segmento especial do Novo Mercado buscaram atenuar os conflitos de agência existentes entre os acionistas controladores e os minoritários no âmbito de um mercado composto, principalmente, por companhias com alta concentração de capital. No entanto, as alterações não tiveram o resultado esperado ${ }^{67}$. Uma das principais alterações da reforma foi o limite de emissão de duas classes de ações em $50 \%$ do capital social, porém, não se observou nenhuma restrição referente ao uso de estruturas piramidais.

\footnotetext{
${ }^{66}$ HALLQVIST, B. Código das melhores práticas de governança corporativa - o conselho de administração. Revista de Administração, v. 35, n 2, p. 72-76, 2000.

${ }^{67}$ GORGA, 2008.
} 
Um dos principais dilemas das estruturas piramidais de participação societária e de outros instrumentos que acarretam a dissociação entre representatividade política e participação econômica é a concentração do poder com estratégias de autoproteção para manutenção do seu status quo.

Essa concentração não se dá somente no âmbito interno da companhia, mas também na maioria das vezes, são acompanhadas no contexto da política externa com a não rara associação de conglomerados econômicos lado a lado de governos ditos democráticos a fim de garantir privilégios de ambas as partes. No entanto, o principal foco deste estudo se dá dentro do ambiente interno das companhias. Através do emprego de mecanismos de dissociação entre a representatividade política e a participação econômica dos acionistas, o controlador passa a deter a prerrogativa de prevalecer nas decisões da assembleia geral voltadas aos seus interesses particulares ${ }^{68}$.

De modo geral, as decisões vantajosas para a companhia tendem a ser também vantajosas para o controlador em modo particular. Tal correlação pode deixar de existir se o controlador tiver uma participação econômica inferior ao seu poder político.

Esse conflito se verifica também em companhias com capital disperso e participação individual pequena. Nesse caso, o absenteísmo nas assembleias gerais pode fazer que o controle de fato seja exercido pelos seus administradores que, na maioria das vezes, também detém pequenas participações do capital social.

Apesar de semelhanças, existem distinções entre uma situação e outra: o administrador, que está de fato exercendo o controle, tem à sua disposição estratégias de autoproteção menos efetivas daquelas exercidas

\footnotetext{
68 Dentre as modalidades de benefícios particulares merecem destaque: (i) pagamentos ou compensações que excedam os valores de mercado; (ii) obtenção de empréstimos com juros inferiores ao de mercado; (iii) transações com partes relacionadas, por exemplo: compra de ativos com valores inferiores ao de mercado; e (iv) uso da companhia para o aproveitamento de oportunidades comerciais e obtenção de amenidades as custas da companhia como privilégios pessoais em clubes exclusivos, etc. AZEVEDO, 2017, p. 402.
} 
pelo acionista controlador com participação minoritária, todavia, com maioria das ações do capital votante. De modo geral, isto está associado e depende da prática adotada pela companhia.

As estruturas piramidais são muito comuns em países emergentes como o Brasil, mas também presentes no sudeste Asiático e na Europa Continental como Alemanha, França e Itália, em virtude de um ambiente de maior concentração da propriedade acionária.

As estruturas piramidais se caracterizam, primordialmente, pela permissão de alto grau de concentração do poder de controle sem que o controlador tenha os custos decorrentes da aquisição de uma participação majoritária. E isto é perfeitamente legítimo, não havendo nada de ilegal na adoção dessa visão. Ainda, em companhias cuja dispersão do capital votante é mais acentuada, essas estruturas societárias se tornam um instrumento de proteção eficaz contra ofertas hostis de controle, servindo como autoproteção de controle dos minoritários.

A partir da década de 90, o Brasil passou a produzir de forma gradativa uma literatura acerca do tema da governança corporativa. Leal Castro e Carvalhal da Silva reuniram uma variedade de estudos acerca do tema. Siffert Filho ${ }^{69}$ reconheceu que as empresas brasileiras vinham apresentando um novo modelo, tendo como principais acionistas investidores institucionais, tanto nacionais como estrangeiros. Isso se deu em razão dos processos de privatizações, do crescimento do controle minoritário em empresas com controle compartilhado e do avanço da presença de capital estrangeiro.

Siqueira $^{70}$ averiguou as mudanças na estrutura de propriedade das companhias brasileiras, possibilitando a identificação dos motivos que levaram a uma maior concentração acionária. Essa pesquisa analisou as

\footnotetext{
${ }^{69}$ SIFFERT FILHO, N. Governança corporativa: padrões internacionais e evidências empíricas no Brasil nos anos 90. Revista do BNDES, nº 9, jun. 1998.

70 SIQUEIRA, T. Concentração da Propriedade nas Empresas Brasileiras de Capital Aberto. Revista do BNDES, n 10, dez. 1998.
} 
companhias conforme a realidade brasileira, tendo em vista que existem companhias com ações com e sem direito a voto. Portanto, partiu-se de duas premissas: (i) participação do maior acionista no capital total e (ii) participação do maior acionista no capital votante. Como resultado, obtevese que: "a firma apresentou um efeito positivo sobre a concentração da propriedade, indicando que existe uma tendência para concentração do controle acionário quando as empresas aumentam de tamanho ${ }^{71}$.

Seguindo nessa perspectiva, Leal Castro e Carvalhal da Silva ${ }^{72}$ analisaram a estrutura de propriedade e controle das companhias brasileiras e o efeito dos direitos de voto e fluxo de caixa sobre o desempenho das companhias ${ }^{73}$. Dessa forma, demonstraram que a propriedade acionária no Brasil é muito concentrada, sendo controlada por um acionista único direto. Desde a análise referida acima, algumas mudanças merecem destaque: (i) no âmbito legislativo com a promulgação da Lei $\mathrm{n}^{\circ}$ 10.303/01, (ii) a abertura de capital de diversas companhias nos anos de 2004 a 2008 e, por fim, (iii) a criação de segmentos de governança corporativa já aqui sinalizados ${ }^{74}$. Em estudo posterior ${ }^{75}$, constatou-se outra realidade, tendo em vista que levou-se em consideração os itens supracitados. Não obstante o controle concentrado predominar no Brasil, o referido estudo expôs uma tendência na redução da concentração ao longo do período analisado. Em companhias com controle definido, se concluiu que há concentração de direito de voto em poder do acionista majoritário, representando, respectivamente, $59,9 \%, 55,5 \%$ e $56,2 \%$ em 2002, 2004 e $2008^{76}$.

\footnotetext{
${ }^{71}$ SILVA, 2002, p. 49.

72 LEAL, R. P. C. Ownership, control, valuation and performance of brazilian corporations. Corporate Ownership and Control. v .4, n. 1, 2006.

${ }^{73}$ Entretanto, as pesquisas de estrutura de propriedade não apresentam consenso no que tange aos impactos sobre o valor e desempenho das companhias.

${ }^{74}$ Nível 1, Nível 2 e Novo Mercado.

75 PEIXOTO, Fernanda Maciel; BUCCINI, Aline Rabelo Assis. Separação entre propriedade e controle e sua relação com desempenho e valor de empresas brasileiras: onde estamos? Revista de Contabilidade e Organizações. $\mathrm{n}^{\circ}$ 17, 2013. p. 48-59.

${ }^{76}$ A razão capital votante sobre capital total vem se reduzindo, o que é positivo para a governança corporativa. Considerando a amostra total, em 2004 esse índice era de 1,45 para o maior acionista controlador, sendo reduzido para 1,33 em 2006 e para 1,28 em 2008. Pode-se inferir que isso tem ocorrido em função das restrições impostas pela Lei $n^{\circ} 10.303 / 01$ e também pela quantidade de
} 
Conforme La Porta ${ }^{77}$, as classes duais de ações e as estruturas piramidais são duas formas de dissociar o fluxo de caixa da companhia e o poder de controle e, assim, aumentar o que chamam de entrincheiramento.

O mercado brasileiro apresenta um percentual acentuado de companhias que se utilizam de estruturas piramidais, conforme demonstrado no trabalho de Aldrighi ePostali, o qual revelou que 50,5\% das companhias abertas analisadas no período de 1997 a 2002 possuíam algum grau de estrutura piramidal ${ }^{78}$.

Constatou-se que $77 \%$ das companhias listadas na bolsa tinham estrutura piramidal e que tais companhias ofereciam dividendos maiores e mais contribuições via impostos ao estado ${ }^{79}$. A mesma autora apresentou evidências que mitigaram os argumentos referentes aos benefícios particulares decorrentes do controle a partir da utilização de estruturas piramidais pelas companhias brasileiras, ou seja, revelou-se que a utilização das estruturas piramidais não está associada com o valor e desempenho das companhias.

As estruturas piramidais revelam-se em decorrência da sobreposição de uma ou mais sociedades holdings de forma que, o acionista tenha participação indireta através de sucessivas posições de controle de cadeia vertical. Ainda, elas podem se tornar mais eficazes quando se apropriam de direitos de controle do que de outras formas de desvios de direitos ${ }^{80}$.

Vamos então compreender como funciona a utilização desse mecanismo com um exemplo fictício. Considere que um acionista é controlador de uma companhia X com $20 \%$ das ações. Por meio da

empresas estreantes na bolsa que optaram pelo Novo Mercado, onde só existem ações ordinárias. SILVA; LEAL, 2006, p. 300-308

77 LA PORTA, R.; LOPEZ DE SILANEZ, F; SHLEIFER, A. Corporate ownership around the world. Journal of Finance, v.54, n. 2, p.471-517, 1999.

78 ALDRIGHI, Dante M; POSTALI, Fernando A. S. Propriedade Piramidal das Empresas no Brasil. In: Revista Economia, Brasilia, v. 12, no 1, jan/abr/2011. p. 46-47

${ }^{79}$ BORTOLON, Patricia. Por que as empresas brasileiras adotam estruturas piramidais de controle. Base - Revista de Administração e Contabilidade da Unisinos 10(1): 2-18, jan./mar. 2013.

80 LIM, U; KIM, C. Determinants of ownership structure: an empirical study of Korean conglomerates. Pacific-Basin Finance Journal. 13, 2005. p. 1-28. 
companhia X, o acionista deseja realizar um investimento na companhia Y. Ora, se o controle é obtido por $20 \%$ das ações da companhia Y e o acionista detém $20 \%$ das ações da companhia X, Y pode ser constituída como uma subsidiária controlada por $\mathrm{X}$, isto é, o acionista da companhia $\mathrm{X}$ controla a companhia X e Y, com direito a $4 \%$ apenas do fluxo de caixa de Y. Se, por outro lado, a companhia Y fosse constituída em uma estrutura horizontal, independentemente da companhia $X, \quad$ o acionista teria que investir diretamente $20 \%$ das ações de Y. Para que conseguisse o controle investindo os mesmos $4 \%$ dos direitos de fluxo de caixa da estrutura piramidal, a companhia Y precisaria ser constituída com $20 \%$ de ações com direito a voto e $80 \%$ com ações sem direito a voto. Da mesma forma, o acionista estaria despendendo mais recursos, uma vez que, além de investir os $20 \%$ da companhia $\mathrm{X}$, teria que adquirir $4 \%$ da companhia $\mathrm{Y}$. Portanto, do ponto de vista do controlador, a estrutura piramidal se torna mais atrativa, pois ele consegue obter o controle com um investimento menor.

Temos a utilização de estruturas piramidais para manutenção do poder de controle, onde em todos os níveis da estrutura o acionista detém mais de $50 \%$ do capital votante e pode exercer o controle de forma isolada. Nesse caso, temos a divisão de 3 grupos: (i) concentração de capital (Figura 1), (ii) manutenção de participação (Figura 2) e (iii) redução da participação do capital (Figura 3$)^{81}$.

\footnotetext{
${ }^{81}$ Exemplos apresentados por Andre Luiz Carvalhal da Silva em: "A influência da estrutura de controle e propriedade no valor, estrutura de capital e política de dividendos das empresas brasileiras". SILVA, 2002, p. 79-80.
} 


\section{Figura 1:}

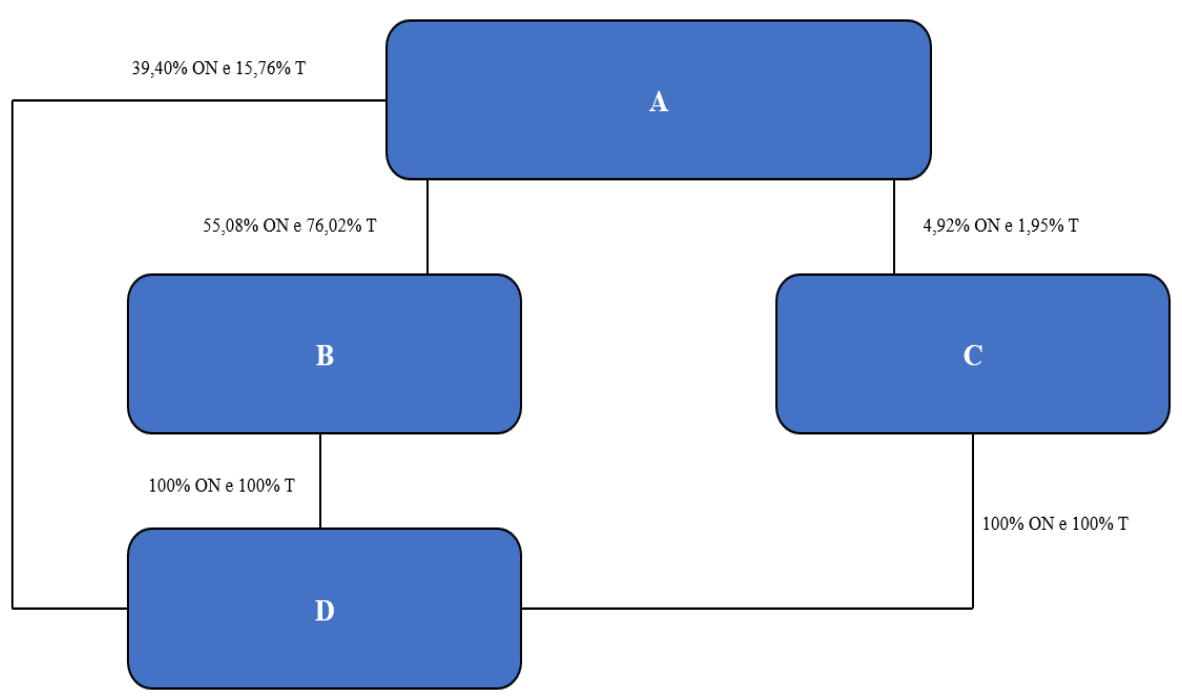

Fonte: "A influência da estrutura de controle e propriedade no valor, estrutura de capital e política de dividendos das empresas brasileiras". SILVA, 2002, p. 79-80.

O caso acima trata de um exemplo de concentração de capital. O controlador direto da companhia A é a companhia B, o qual detém 55,08\% do capital votante e $76,02 \%$ do capital total (T). Entretanto, a companhia D possui indiretamente o controle da companhia A, por meio de participações nas companhias B e C e diretamente na própria companhia A, com 99,40\% do capital votante e 93,73 do capital total. Dessa forma, por meio de vias indiretas, o controle detido pela companhia D aumenta de 55,08\% para $99,40 \%$ do capital votante.

\section{Figura 2:}

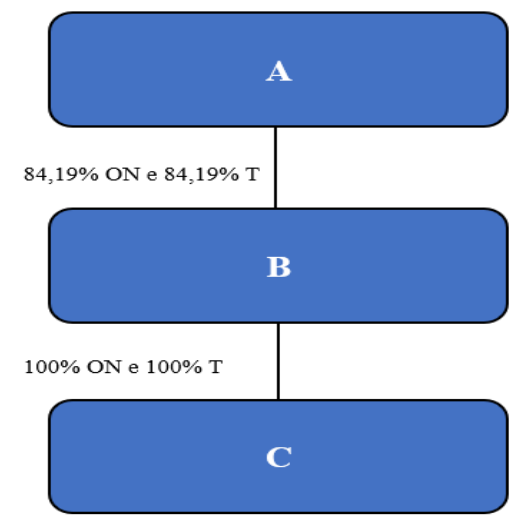

Fonte: "A influência da estrutura de controle e propriedade no valor, estrutura de capital e política de dividendos das empresas brasileiras". SILVA, 2002, p. 79-80. 
Na figura 2, podemos observar um exemplo de manutenção do poder de controle e da participação societária. A Companhia C, controladora indireta, detém $100 \%$ da companhia B e, por essa razão, ela controla indiretamente a companhia A com a mesma proporção do capital que, nesse caso, é de $84,19 \%$ do capital votante e total.

\section{Figura 3:}

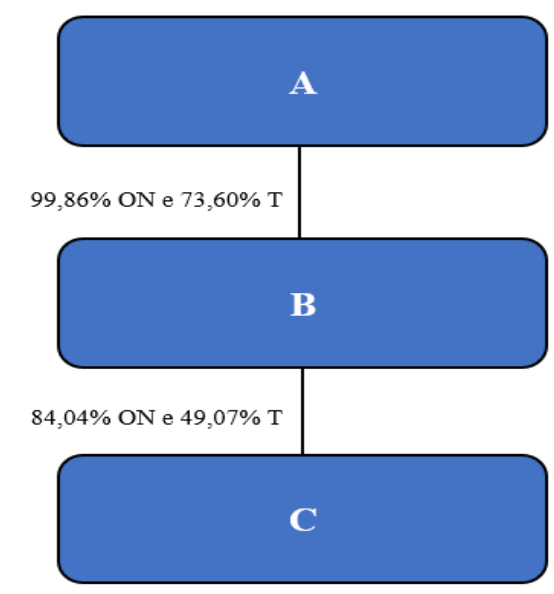

Fonte: "A influência da estrutura de controle e propriedade no valor, estrutura de capital e política de dividendos das empresas brasileiras". SILVA, 2002, p. 79-80.

Por fim, no último exemplo, temos a hipótese de manutenção de controle por um acionista que possui indiretamente uma participação do capital menor que diretamente. O controlador direto da companhia A é a companhia B, a qual detém $99,86 \%$ do capital votante e $73,60 \%$ do capital total. Todavia, a companhia $\mathrm{C}$ possui indiretamente o controle da companhia, por meio de seu investimento na companhia B. Assim sendo, a companhia C possui indiretamente $99,86 \%$ do capital votante e apenas 36,11\% do capital total. Logo, por meio de uma estrutura de pirâmide vertical, o acionista controlador consegue manter o controle da companhia A, detendo $99,86 \%$, mas o capital total é reduzido de $73,60 \%$ para $36,11 \%$.

Os exemplos acima explicitam claramente as razões pela utilização das estruturas piramidais como mecanismos de se obter o controle societário com menor aporte de capital, a depender do objetivo do acionista. 
Leal e da Silva $^{82}$ revelam que esses mecanismos continuam sendo amplamente empregados com intuito de concentrar o controle com investimento reduzido. Ainda, os autores constataram que "o valor $e$ performance são positivamente relacionados com a concentração do fluxo de caixa e negativamente relacionados com a concentração de controle" ${ }^{\text {" } 33}$.

Passamos agora à análise de casos concretos de companhias brasileiras que apresentam na sua composição acionária estruturas piramidais como forma de alavancagem financeira, conforme observado nos organogramas das empresas do grupo Gerdau e da Bradespar (Figuras 4 e 5, respectivamente), como segue:

\section{Figura $4^{84}$ : Organograma Gerdau}

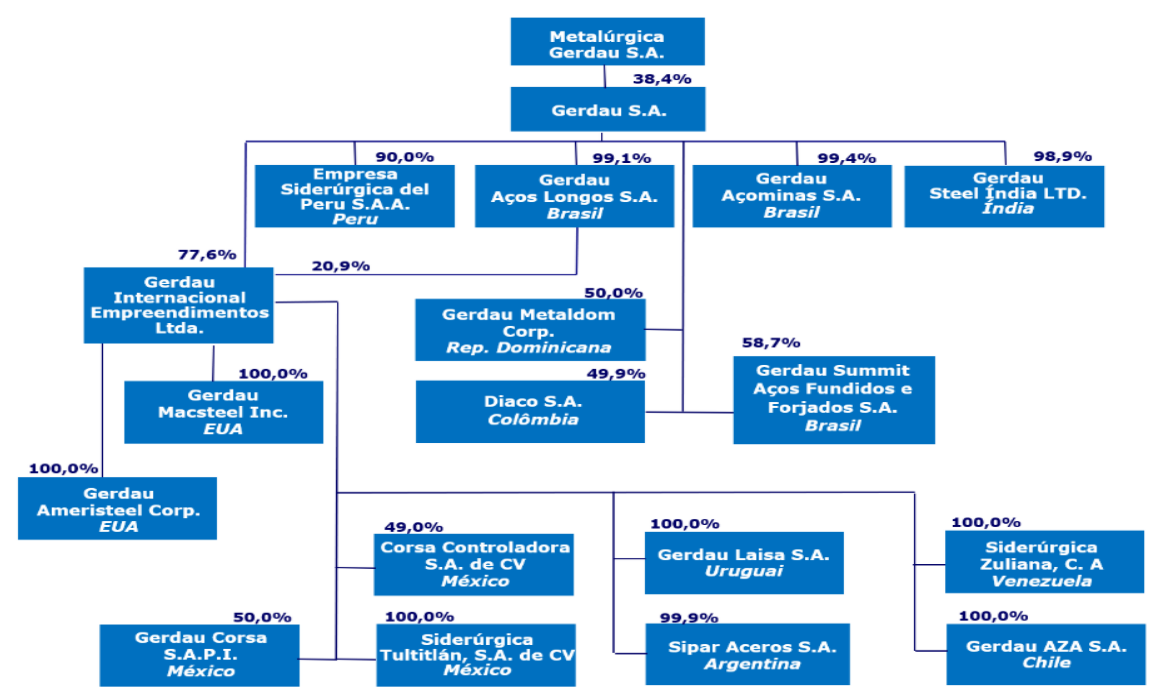

Fonte: Disponível em: <http://ri.gerdau.com/static/ptb/estrutura-societaria.asp?idioma=ptb>. Acesso em: 04 nov.2018..

\footnotetext{
${ }^{82}$ LEAL, R.P.C; CARVALHAL DA SILVA, A. L; VALADARES, S. M. Estrutura de Controle das Companhias Brasileiras de Capital Aberto. Revista de Administração Contemporânea. v. 6, n. 1, p. 7-18, 2002.

${ }^{83}$ Ibid., p. 7-18. Entretanto, a conclusão não é uma posição unânime, tendo diversos estudos que demonstram o contrário.

${ }^{84}$ Disponível em: <http://ri.gerdau.com/static/ptb/estrutura-societaria.asp?idioma=ptb〉. Acesso em: 04 nov. 2018.
} 
Figura $5^{85}$ : Organograma Bradespar

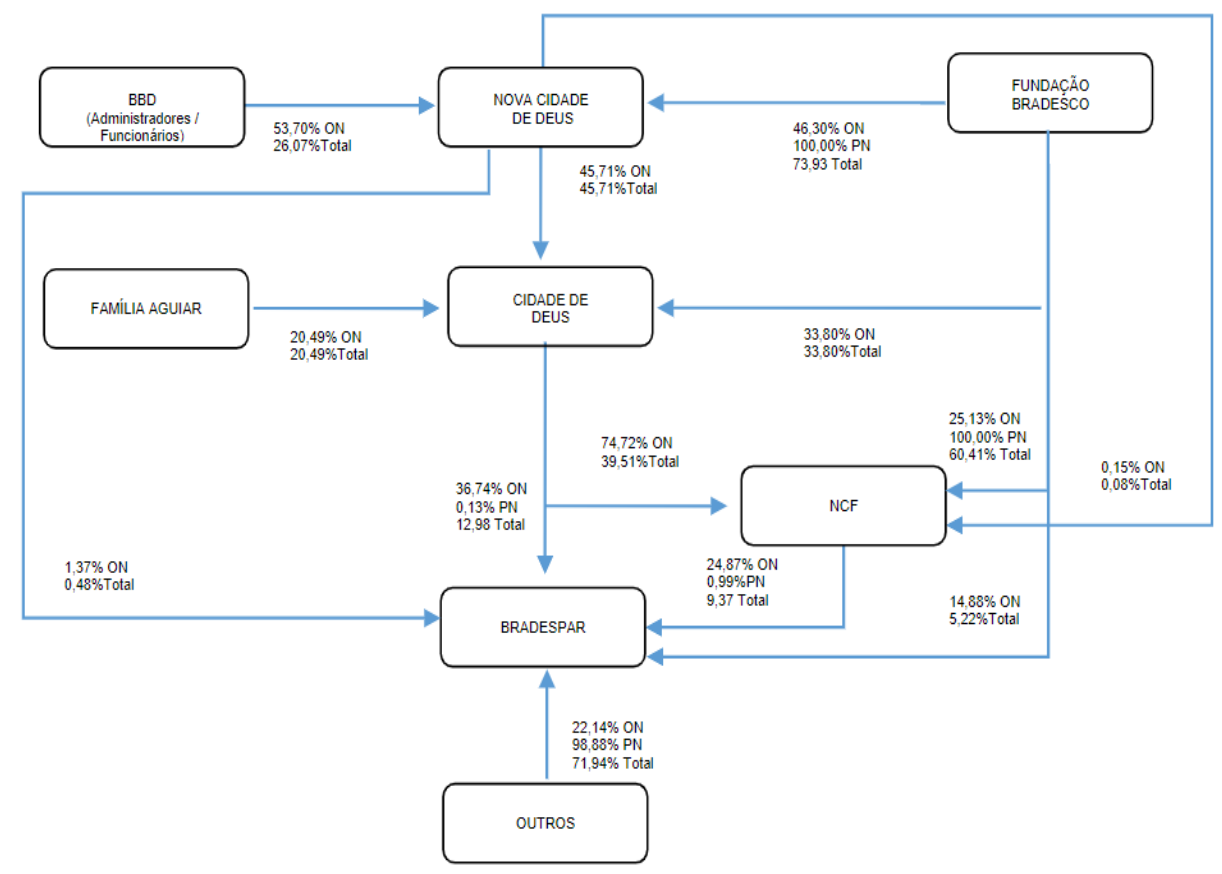

Fonte: Disponível em:

<https://www.rad.cvm.gov.br/enetconsulta/frmGerenciaPaginaFRE.aspx?CodigoTipoInstituicao=1 $\&$ NumeroSequencialDocumento=78573>. Acesso em: 04 nov.2018.

\subsubsection{Grupo Gerdau}

O Grupo Gerdau, por figurar na posição de grupo empresário familiar, compreende-se a razão pela utilização de estruturas piramidais como mecanismos de alavancagem financeira, como forma de concentração do poder para a família, uma vez que esta não estaria disposta a compartilhar o poder de controle das companhias do grupo com os outros acionistas.

O Grupo adotou esse modelo a partir de 1969, com a legitimação da Metalúrgica Gerdau S.A como holding do grupo, o qual adquiriu forma concreta em 1975, determinando as funções decisórias e executivas do

\footnotetext{
${ }^{85}$ Disponível em: <https://www.rad.cvm.gov.br/enetconsulta/frmGerenciaPaginaFRE.aspx?CodigoTipoInstituicao=1 \&NumeroSequencialDocumento=78573>. Acesso em: 04 nov. 2018.
} 
grupo como um todo. Esse modelo é típico no mercado empresarial brasileiro. Nesse sentido, o $\operatorname{IBGC}^{86}$ salienta que:

empresas de controle familiar, portanto, estabelece as relações não apenas no âmbito da separação entre propriedade e gestão (como no caso das empresas não familiares), mas no âmbito das relações entre família, patrimônio societário (propriedade) e empresa (gestão). Como consequência, o sucesso na questão da governança de empresas familiares depende da capacidade da família definir sua atuação nessas três esferas, criando mecanismos formais e legais para administrar suas diferenças e conflitos.

No final dos anos 80, com a conjuntura de desenvolvimento e modernização econômica, o Brasil passou a universalizar o uso da expressão "Grupo" entre as companhias brasileiras. Essa realidade era encontrada primordialmente entre os conglomerados do setor industrial, o mais dinâmico e modernizador e que puxava o desenvolvimento nacional.

O organograma do Grupo Gerdau nos revela claramente o seu objetivo. A pluralidade de companhias com objetos e interesses distintos e a possibilidade de diversificação de investimentos é um dos motivos pela utilização de holdings verticais com objetivo de alavancagem financeira. Nota-se, ainda, que a Gerdau S.A. e a Metalúrgica Gerdau S.A. são companhias abertas listadas no segmento Nível 1 da B3, o que representa que estão conscientes com as práticas mais modernas e transparentes no que tange à governança corporativa.

\subsubsection{Bradespar}

Atualmente, o capital social da Bradespar é constituído por 348.034.045 ações, sendo 122.171.449 ações ordinárias e 225.862.596 ações preferenciais, sem valor nominal. A companhia tem como controladora direta a Cidade de Deus Companhia Comercial de Participações (“Cidade de Deus”), que é uma holding, e detém 36,74\% do

\footnotetext{
${ }^{86}$ IBGC. Instituto Brasileiro de Governança Corporativa. Governança Corporativa em empresas de controle familiar: casos de destaque no Brasil. São Paulo: Saint Paul Editora, 2007. p. 23.
} 
capital votante e 12,98\% do capital total da Bradespar. A Cidade de Deus, por sua vez, tem como acionistas (i) a Nova Cidade de Deus ("Nova Cidade de Deus"), com 45,71\% de suas ações ordinárias e do capital total; (ii) a Fundação Bradesco, com 33,80\% de suas ações ordinárias e do capital total; e (iii) a Família Aguiar, com 20,49\% de suas ações ordinárias e do capital total ${ }^{87}$.

A Nova Cidade de Deus possuí diretamente $1,37 \%$ de ações ordinárias e $0,48 \%$ do capital total da Bradespar. Sua participação direta na Bradespar era de 1,37\% de ações ordinárias e 0,48\% do capital total, entretanto, possuí indiretamente, por meio de sua participação na Cidade de Deus e NCF Participações S.A., 21,31\% de ações ordinárias e 7,64\% do total de ações da Bradespar.

A Fundação Bradesco detém, direta e indiretamente, por meio de sua participação na Cidade de Deus, Nova Cidade de Deus e NCF, 62,41\% de ações ordinárias, $0,95 \%$ de ações preferenciais e $22,53 \%$ do total de ações da Bradespar.

A BBD Participações S.A. ("BBD”) possuí indiretamente 5,91\% das ações ordinárias e 2,12\% do total das ações da Bradespar, por meio de sua participação na Nova Cidade de Deus ${ }^{88}$.

A NCF Participações ("NCF") é uma empresa holding controlada pela Cidade de Deus e a Fundação Bradesco. A NCF possui diretamente 24,87\% de ações ordinárias e 9,37\% do total de ações da Bradespar.

Como já estudado neste trabalho, as estruturas piramidais são mecanismos legítimos utilizados para se obter o controle de companhias com menor investimento do que por uma participação direta. É o que pode

\footnotetext{
${ }^{87}$ Disponível em:

<https://www.bradespar.com.br/Bradespar/Portugues/Documentos/FR_Bradespar_Port_V3.pdf $>$. Acesso em: 04 nov. 2018.

${ }^{88}$ Segundo o Formulário de Referência da Companhia só podem deter ações da BBD, membros do Conselho de Administração e Diretoria Estatutária do Bradesco e da BRADESPAR, bem como funcionários qualificados. Entretanto, somente os Conselheiros e Diretores Estatutários podem possuir ações com direito a voto. A maioria dos membros do Conselho de Administração e da Diretoria Estatutária possui ações na BBD.
} 
ser observado no organograma da Bradespar exposto na figura 5 acima, onde o Grupo controlador, composto pelo Cidade de Deus, Nova Cidade de Deus, Fundação Bradesco e NCF, consegue, por via direta e indireta (constituição vertical de holdings), deter a maioria das ações com direito a voto da companhia.

\subsubsection{Estruturas Piramidais no Novo mercado}

A partir do estudo de Aldrighi e Postali tem se a constatação de que apenas $8,5 \%$ das companhias que integravam estruturas piramidais pertenciam ao Novo Mercado ${ }^{89}$. Tal fato permitiu concluir que o ingresso no Novo Mercado reduz a probabilidade de a companhia vir a integrar uma estrutura piramidal, uma vez que ela está associada à prática de governanças corporativas que diminuam a expropriação de investidores, como a desproporção entre o direito de propriedade e o direito econômico, só permitindo que as companhias emitam ações ordinárias.

Um dos objetivos da criação do Novo Mercado foi a tentativa de reduzir os custos de agência existentes entre acionistas controladores e os minoritários, entretanto, não se obteve o resultado desejado ${ }^{90}$. Com o advento da Lei ${ }^{\circ}$ 10.303/01, se alterou o limite da porcentagem de emissão de ações preferenciais consoante ao capital total da companhia (50\%), porém, no que tange às restrições acerca de estruturas piramidais, nada pode ser encontrado. Pelo contrário, a quantidade de companhias que se utilizou desse mecanismo aumentou gradativamente durante o período analisado, conforme se verá no caso da Cosan Limited apresentado abaixo.

\footnotetext{
${ }^{89}$ ALDRIGHI; POSTALI, 2011, p. 17.

${ }^{90}$ GORGA, 2008.
} 


\subsubsection{COSAN}

Figura $6^{91}$ - Organograma Cosan

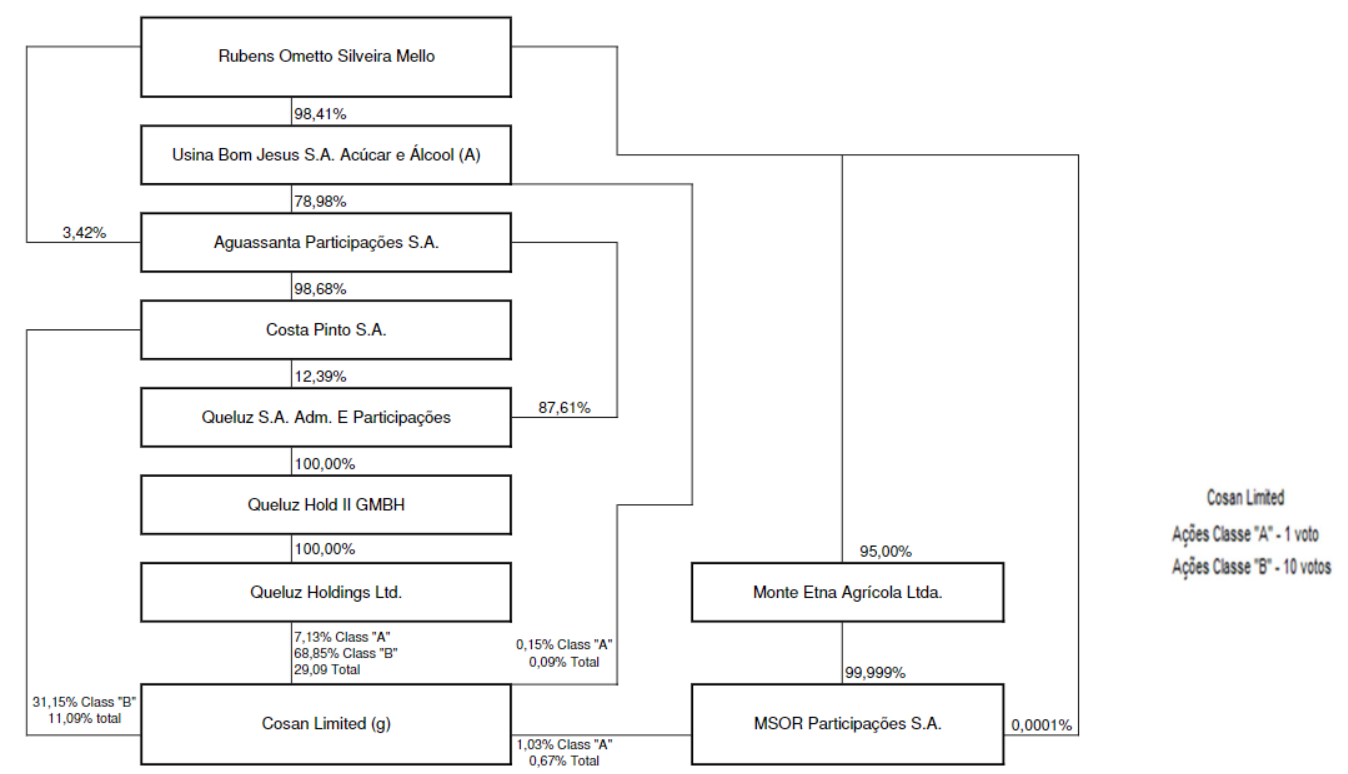

Fonte: Disponível em:

<https://www.rad.cvm.gov.br/enetconsulta/frmGerenciaPaginaFRE.aspx?CodigoTipoInstituicao=1 \&NumeroSequencialDocumento=76072>. Acesso em: 28 out. 2018.

O exemplo da Cosan é um caso bem emblemático, uma vez que a companhia faz parte do segmento do Novo Mercado, segmento de governança corporativa mais alto no mercado de capitais brasileiro, o que pode não ser bem recebido por parte de alguns investidores, em razão das práticas adotadas. Na época, o empresário Rubens Ometto controlava indiretamente a Cosan Operacional através de participação (também indireta) que este detinha na Aguassanta Participações e na Usina Costa Pinto, as quais detinham o controle de $51,25 \%$ do capital da companhia. Conforme o organograma, para se chegar no beneficiário final temos que percorrer por toda cadeia piramidal repleta de holdings. Em julho de 2007, Rubens Ometto propôs aos acionistas minoritários que eles migrassem para a Cosan Limited por meio de aquisição de ações com direito a voto dez vezes menor que as ações detidas pelo próprio controlador.Apesar das

\footnotetext{
${ }^{91}$ Disponível em: <https://www.rad.cvm.gov.br/enetconsulta/frmGerenciaPaginaFRE.aspx?CodigoTipoInstituicao=1 $\&$ NumeroSequencialDocumento=76072>. Acesso em: 28 out. 2018.
} 
críticas por parte dos acionistas minoritários, o empresário Rubens Ometto deu prosseguimento à restruturacao societária do Grupo Cosan, que consistia na (i) criação da Cosan Limited, seu IPO e a Oferta Global de Permuta. ${ }^{92}$ Cumpre destacar que a companhia já apresentava alto grau de alavancagem financeira antes mesmo deste comunicado pelo controlador e da criação da Cosan Limited. Atualmente, a companhia ainda é controlada pelo empresário por meio da cadeia piramidal de holdings do grupo e, conforme amplamente demonstrado neste trabalho, através das estruturas de alavancagem, o controlador incorre em menos custos pessoais quanto aos efeitos do fluxo de caixa da companhia controlada. Vejamos os fundamentos: à medida que o acionista aumenta o poder político em uma companhia, sem em contrapartida incorrer nos custos necessários, este passa a perder o interesse econômico na companhia controlada. Em termos práticos, o acionista controlador sofre menos com os efeitos do fluxo de caixa da controlada. Dessa forma, o acionista controlador pode ser incentivado a celebrar contratos entre partes relacionadas a fim de repassar os lucros da controlada para a companhia controladora, a qual este detém participação maior.

Segundo Álvaro Bandeira, presidente da Associação dos Profissionais de Investimento do Mercado de Capitais (APIMEC Nacional), o mercado será responsável pela precificação dos benefícios e possíveis prejuízos decorrentes das estruturas piramidais ${ }^{93}$.

\subsubsection{Síntese Conclusiva}

O sistema de estruturas piramidais apresenta algumas vantagens ${ }^{94}$, nessa conformidade essa estrutura ensejaria a possibilidade do surgimento

\footnotetext{
${ }^{92}$ Disponível em: <http://sistemas.cvm.gov.br/dados/LaudEditOpa/RJ-200712218/20080306_POSPECTO_DE_OFERTA_P\%C3\%9ABLICA.pdf>. Acesso em: 05 nov.2018 93 Disponível em: <https://capitalaberto.com.br/temas/poucas-acoes-muitosvotos/\#.W_PuSjhKjIU>. Acesso em: 15 nov.2018.

${ }^{94}$ Masulis et al. (2009), analisando estruturas piramidais em 45 países e os impactos sobre o valor da firma, encontram evidências favoráveis à vantagem de financiamento, sendo os grupos
} 
de um mercado de capitais interno capaz de permitir às sociedades participantes (i) a "obtenção de domincação por um grupo de acionistas relevantes, contra outro grupo acionistas titulares de participações expressivas na companhia"95; e (ii) "[ser] possível que [as estruturas piramidais] sirvam a diversas estratégias, como por exemplo, criar uma cunha entre direitos de votos e fluxos de caixa, facilitar o financiamento, ou reduzir tributação"96."

Por outro lado, a literatura sobre o tema demonstra que as estruturas de propriedade e um ambiente com baixa proteção legal aos investidores apresentam um risco moral, em razão da (i) desvirtuação do princípio one share, one vote, (ii) do entrincheiramento e potencial expropriação dos acionistas minoritários e (iii) da perpetuação no poder de controle por parte de alguns acionistas. Ainda, podemos constatar que essas estruturas podem gerar situações de conflito de interesses nas operações com partes relacionadas $^{97}$.

Não obstante os benefícios supracitados, ainda fica a discussão de que a estrutura piramidal tem como finalidade, em último caso, a concentração do controle do capital em detrimento dos acionistas minoritários.

empresariais um importante substituto para o mercado financeiro como fonte de financiamento de projetos, especialmente em mercados pouco desenvolvidos. BORTOLON, 2013, p. 04.

95 VALADARES, Silvia M.; e LEAL, Ricardo P.C. Ownership and Control Structure.. In Revista Abante, v.3, 2000, p.05.

96 ALDRIGHI; MAZZER NETO, 2007, p. 16.

97 Conforme demonstram o prospecto do IPO da Cosan Limited em 2005 e do IPO da Springs Global Participações S.A, em 2007. Nesse sentido: "We engage in business and financial transactions with our controlling shareholder and other shareholders that may create conflicts of interest between our company and these shareholders. "For example, we enter into land leasing agreements with our affiliates, including Amaralina Agrícola Ltda, or "Amaralina", Santa Bárbara Agrícola S.A., or "Santa Bárbara" and São Francisco S.A., or "São Francisco". The accounts payable balances result mainly from the lease of agriculture land, which are at prices and on terms equivalent to the average terms and prices of transactions that we enter into with third parties. Commercial and financial transactions between our affiliates and us, even on if entered into on an arm's length basis, create the potential for, or could result in, conflicts of interests".

Disponível em:

<https://www.sec.gov/Archives/edgar/data/1402902/000119312507141382/df1.htm\#rom37482_1 4>. Acesso em: 17 nov. 2018. 


\subsection{Estruturas Acionárias Duais}

As estruturas acionárias que estamos tratando neste capítulo podem se valer de dois tipos: ações com voto unitário, respeitando o conceito do "one share, one vote" e ações com voto plural; ou (ii) de ações com direito a voto e ações sem direito a voto, sendo garantido às últimas participação igualitária ou preferencial ${ }^{98}$ (ações preferenciais - art.17 da LSA) nos dividendos.

Essas conformações foram tema de debate no âmbito do Decreto $\mathrm{n}^{\circ}$ 21.536, de 1932, o qual estabeleceu no Brasil a regra do "one share, one vote", ou seja, cada ação ordinária corresponde a um voto nas deliberações assembleares, sendo respeitado o princípio da proporcionalidade entre o capital investido e a participação política na companhia. Tal princípio foi consagrado no art.110, da LSA, que acabou proibindo o voto plural no Brasil.

Esse princípio vem sendo questionado ao longo da história do mercado de capitais brasileiro. A título de ilustração, cabe mencionar alguns exemplos que a LSA excepciona o princípio do one share, one vote: (i) limitação de $50 \%$ do capital social em ações preferenciais (art.15 LSA) $)^{99}$; (ii) alteração do limite do capital autorizado (art.168 LSA) ${ }^{100}$; (iii)

\footnotetext{
${ }^{98}$ Art. 17 da LSA - as ações preferenciais não serão objeto de análise deste trabalho.

${ }^{99}$ Art. 15. LSA. As ações, conforme a natureza dos direitos ou vantagens que confiram a seus titulares, são ordinárias, preferenciais, ou de fruição. [...] § 2º O número de ações preferenciais sem direito a voto, ou sujeitas a restrição no exercício desse direito, não pode ultrapassar $50 \%$ (cinquenta por cento) do total das ações emitidas.

${ }^{100}$ Art. 168. O estatuto pode conter autorização para aumento do capital social independentemente de reforma estatutária. § $1^{\circ}$ A autorização deverá especificar: a) o limite de aumento, em valor do capital ou em número de ações, e as espécies e classes das ações que poderão ser emitidas; b) o órgão competente para deliberar sobre as emissões, que poderá ser a assembleia-geral ou o conselho de administração; c) as condições a que estiverem sujeitas as emissões; d) os casos ou as condições em que os acionistas terão direito de preferência para subscrição, ou de inexistência desse direito (artigo 172). $\S 2^{\circ} \mathrm{O}$ limite de autorização, quando fixado em valor do capital social, será anualmente corrigido pela assembleia-geral ordinária, com base nos mesmos índices adotados na correção do capital social. $\S 3^{\circ} \mathrm{O}$ estatuto pode prever que a companhia, dentro do limite de capital autorizado, e de acordo com plano aprovado pela assembleia-geral, outorgue opção de compra de ações a seus administradores ou empregados, ou a pessoas naturais que prestem serviços à companhia ou a sociedade sob seu controle.
} 
plano de outorga de ações (art.171, $\S 3^{\circ}$ LSA) ${ }^{101}$; (iv) ações gravadas com usufruto (art.114 LSA) ${ }^{102}$; (v) limitação do número de votos por acionistas (art.110, $\S \S 1^{\circ}$ e $2^{\circ}$ LSA); e (vi) golden shares. Ora, esses exemplos demonstram claramente que, embora a lei estabeleça esse princípio em seu art.110, a dissociação entre a participação econômica e a participação política na companhia ocorre de maneira contínua, não apenas como exceção.

O direito de voto é o direito do acionista de manifestar sua vontade no âmbito da assembleia geral da companhia. É através dele que o acionista informa aos demais participantes da assembleia sua opinião acerca de determinada matéria, contribuindo para a formação da vontade social.

Destaca-se que a LSA não conferiu ao direito de voto o caráter essencial conforme previsto no art. 109 da LSA, e o incluiu na categoria de direitos próprios ou reservados a determinados acionistas.

\begin{abstract}
A lei brasileira, ao enunciar, no artigo 109, os direitos essenciais do acionista, não menciona o de voto porque admite ações preferenciais sem voto (art.111); mas o princípio da proporcionalidade se aplica, por igual, às ações preferenciais da mesma classe por forca do par 1 do artigo 109, segundo o qual as ações de cada classe devem conferir iguais direitos a seus titulares ${ }^{103}$.
\end{abstract}

Segundo Lamy e Bulhões ${ }^{104}$, o direito de voto pode ter duas classificações quanto à sua natureza: (i) direito subjetivo e (ii) direito-dever. O direito de voto é direito subjetivo porque o exercício dele ou não está a critério do acionista; e o direito de voto é direito-dever, quando se refere ao conteúdo do voto, uma vez que esse deve ser exercido de acordo com o interesse da companhia.

\footnotetext{
101 Art. $171[\ldots] \S 3^{\circ}$ Os acionistas terão direito de preferência para subscrição das emissões de debêntures conversíveis em ações, bônus de subscrição e partes beneficiárias conversíveis em ações emitidas para alienação onerosa; mas na conversão desses títulos em ações, ou na outorga e no exercício de opção de compra de ações, não haverá direito de preferência.

102 Art. 114. O direito de voto da ação gravada com usufruto, se não for regulado no ato de constituição do gravame, somente poderá ser exercido mediante prévio acordo entre o proprietário e o usufrutuário.

${ }^{103}$ LAMY FILHO, Alfredo; PEDREIRA, José Luiz Bulhões. A Lei das S.A.. v. 2, $2^{\mathrm{a}}$ ed. Rio de Janeiro: Renovar, 1996. p. 72.

${ }^{104}$ LAMY FILHO et al., 2017, p. 280.
} 
O direito societário pátrio adotou diferentes institutos que desmistificam o princípio do "one share, one vote", e trata o direito de voto como direito conferido a determinada classe de ação (ordinária). Entende-se que o interesse do acionista pode se desmembrar em duas faces: o direito político, que é o direito conferido ao acionista para exercício do o voto nas assembleias gerais; e o direito econômico, que é o direito de auferir os lucros advindos da propriedade da ação.

\begin{abstract}
Portanto, a Lei 6.404-76 visaria a atender e a acomodar os objetivos do empresário e do investidor. Se este não quer o direito de voto, mas sim o lucro, então, que se possa suprimir suas prerrogativas políticas e fortalecer suas vantagens patrimoniais, sempre dispondo que, se a companhia não lhe outorgar a efetiva vantagem, que se lhe devolva o direito de voto, como prevê o art. 111, § $1^{\circ}$. Para os autores do anteprojeto o investidor prefere maior proteção patrimonial à política, o que talvez ajude a explicar o "sucesso" das ações preferenciais (culminando nas malfadadas reformas de 1997 e 2001) como instrumento de financiamento a que recorreram as grandes companhias nacionais e que o mercado em geral tendeu a aceitar ${ }^{105}$.
\end{abstract}

Por essa razão, a LSA admite essa separação entre esses dois interesses, sendo certo que a adoção ou não desses mecanismos deverá ficar a critério da companhia e dos acionistas em sede de assembleia geral.

\title{
4.2.1. Perspectiva Geral
}

Frequentemente se vê, nos últimos anos, que é necessária uma reformulação do funcionamento do mercado de capitais, o qual é influenciado pela predominância de um modelo de investimento baseado no curto prazo e que resulta numa "early and exit culture". Em caso de conflito de governança, os acionistas tendem a preferir a venda de suas ações no mercado (exit), ao invés de manterem a participação social e tentarem solucionar o conflito através do exercício do voto (voice $)^{106}$.

\footnotetext{
105 ADAMEK, Marcelo Vieira Von (Coord.). Temas de Direito Societário e Empresarial Contemporâneos. PC Editorial Ltda., 2011. p. 294.

106 SANTOS, João Vieira dos. Ações de Lealdade. A primazia dos interesses da estabilidade a longo prazo da empresa social. Revista de Direito das Sociedades, n⿳2 2, 2014, p. 445-480.
} 
A necessidade de se alterar essa tendência se deu, especialmente, após a crise de 2008, que se passou a defender que a chave para um desenvolvimento sustentável é o investimento a longo prazo ${ }^{107}$. Por outro lado, a crise constatou riscos da alavancagem e se iniciou um processo de desalavancagem por diversos bancos, o que provocou uma escassez de financiamento a longo prazo ${ }^{108}$.

Afigura-se, nessa medida, necessário apostar em formas alternativas de financiamento, como o financiamento direto junto ao mercado de capitais. Mas para tal, é essencial tornar o mercado atraente, tendo como alternativa a possibilidade de as companhias criarem categorias de ações com voto plural, o qual será objeto de análise no próximo item.

\subsubsection{Voto Plural no Direito Comparado}

\subsubsection{Itália}

De fato, o Código de Comércio Francês de 1807, adotado também em parte da Itália, não incluiu qualquer limitação à emissão de ações com direito ao voto plural e aos códigos comerciais italianos de 1865 e 1882 era concedida liberdade semelhante, ainda que esta última proibisse a emissão de ações sem direito de voto. No final do século XIX e início do século XX, a questão foi intensamente debatida, e a ideia de que todos os acionistas deveriam ter direitos iguais ganhara força. No entanto, a inflação acentuada após a Primeira Guerra Mundial levou a certas preocupações no que se refere às aquisições hostis de controle de companhias italianas por investidores estrangeiros (principalmente os americanos) e o uso de ações com direito ao voto plural foi novamente reformulado. Somente com o Código Civil de 1942, e novamente após ampla discussão e propostas

${ }^{107}$ ZHAO, Jingchen. Corporate social responsibility in contemporary China. Massachusetts, 2014. p. 260.

108 OLIVEIRA, Madalena Perestrelo de. Direito de voto nas Sociedades Cotadas Portuguesas: da admissibilidade de categorias de ações com direito de voto plural às L-Shares. Revista de Direito das Sociedades e dos Valores Mobiliários. v. 6a ed. Almedina, nov. 2017. p. 264. 
conflitantes, que as ações com direito ao voto plural foram proibidas e permaneceram um tabu até sua recente reforma.

A lógica subjacente a esta aparente incoerência entre a participação no capital e o direito de voto, seria a de que as ações em que se admitia a quebra do princípio "one share, one vote" tinham como objetivo evitar uma elevada concentração de votos nas mãos de poucos acionistas, enquanto o voto plural tinha como intuito exatamente o contrário, propiciando, dessa forma, um conjunto de situações em que o acionista controlador pudesse auferir benefícios particulares frente ao controle societário.

Em agosto de 2015, o governo italiano, como parte de um pacote de reformas projetado para tornar o mercado de capitais mais atrativo para as companhias de capital fechado - mas, também para aumentar ainda mais a liberdade contratual no direito societário - permitiu que as companhias emitissem ações com voto plural e ações de lealdade (Loyalty Shares), as quais atribuem aos seus titulares de longo prazo maior direito de voto.

Ao fazê-lo, o governo italiano se juntou a vários outros estados europeus e americanos e aboliu um velho tabu da lei societária italiana. Isto também ofereceu aos investidores, executivos de empresas, reguladores e acadêmicos um ótimo teste para o uso deste dispositivo e seus efeitos sobre o tema da manutenção do poder de controle.

Nessa seara, o governo italiano introduziu ações com voto plural alguns meses após a migração da Chrysler-Fiat, uma das mais importantes corporações multinacionais italianas, para a Holanda. A Chrysler-Fiat, de fato, se reconstituiu na Holanda em 2014, também para aproveitar as características específicas da governança corporativa do sistema holandês e, especificamente, a possibilidade de emissão de ações com voto plural. O receio de perder uma das maiores companhias nacionais, foi um dos principais motivos que contribuíram para a decisão do governo italiano de introduzir as ações com voto plural em seu diploma legal. 
Como destacado, a edição, em 31 de dezembro de 2014, do Decreto Competitivitá, alterou o panorama societário italiano radicalmente, tendo como linha orientadora o desenvolvimento e a promoção do acesso ao mercado de capitais.

Primeiramente, vale destacar a alteração feita no art. 2351, par 4, Codice, que determinou que as companhias fechadas podem emitir categoria de ações com voto plural, ainda que limitadas na sua utilização à votação em assuntos específicos e tendo um limite máximo de três votos por ação ${ }^{109}$. Já as companhias listadas em mercado regulamentado, não podem criar categorias de ações com direito ao voto plural (art.127, par 2, sexsies TUF).

Em segundo lugar, foram criadas as ações com voto maggiorato, que correspondem às ações de lealdade (Loyalty Shares), classificadas como investimentos de longo prazo, uma vez que sua titularidade ininterrupta por um período de 24 meses confere ao seu titular - no máximo - dois votos por ação. Todavia, caso o titular das ações as aliene em um prazo menor, isso implicaria na perda da majoração dos votos, salvo se a transferência se der por causa mortis, fusão ou cisão.

A majoração do direito de voto é vista como uma maneira de promover a entrada de companhias no mercado de capitais, de forma que se aumente o free float no momento do IPO (Initial Public Offer), sem que isso implique a perda do poder de controle da companhia.

Nesse contexto, nota-se que as ações com voto de lealdade não são classificadas como categorias de ações, não cabendo direito de recesso com sua introdução no estatuto da companhia. Por outro lado, as ações de voto plural são classificadas como classe de ações, sujeita a todas as regras a elas aplicáveis. Consequentemente, uma companhia pode emitir diferentes classes de ações com voto plural, com diferentes direitos de voto (por exemplo, um com dois votos por ação e um com três votos por ação). O 
direito de voto diferenciado não pode ser multiplicado através do mecanismo das ações de lealdade, a fim de evitar concentração do poder com um investimento limitado (por exemplo, estabelecendo ações com direito de voto, ações de lealdade, e ações com direito limitado, em teoria, um acionista poderia ter controle majoritário com um investimento igual a $6,25 \%$ do capital).

A introdução destas categorias de voto plural nas companhias abertas - categorias de ações e ações de lealdade (voto maggiorato) - foi acompanhada de novas regras no que tange aos deveres de informação e transparência com os acionistas e ao mercado ${ }^{110}$.

Apesar das grandes alterações com respeito ao voto plural, não podemos deixar de destacar que a nova legislação foi alvo de grandes críticas: (i) o proxy advisor "Frontis Governance" foi contra a introdução das ações de lealdade nas companhias listadas em bolsa; e (ii) o ISS (Institutional Shareholders Services) foi contra qualquer estrutura de dualidade de classes de direito de voto.

\subsubsection{França}

A Lei Francesa, assim como a Italiana, proibia o voto plural. No entanto, permitia o voto "aumentado", desde que as ações fossem nominativas e os acionistas mantivessem a titularidade das ações de forma ininterrupta por prazo mínimo de dois anos.

A “Lei no 2014-384” (Lei Florange) modificou a regra antiga, uma vez que atualmente as companhias se beneficiam automaticamente das ações de lealdade, a não que ser que os acionistas deliberem por sua exclusão. Sendo assim, todos os acionistas que detenham ações por dois anos consecutivos possuirão direito ao voto plural. Em termos práticos, as companhias que queiram manter a proporcionalidade entre o capital

\footnotetext{
${ }^{110}$ OLIVEIRA, 2017, p. 217.
} 
investido e o direito de voto, ou seja, o princípio do "one share, one vote", deverá convocar, no prazo de dois anos, uma assembleia geral extraordinária, a fim de deliberar acerca da alteração do estatuto social da companhia.

Curiosamente, em 2014, a legislação francesa tornou as "ações de lealdade" a regra padrão das companhias listadas em bolsa (as companhias podem optar por não adotar). Entretanto, na realidade, a maioria das companhias francesas listadas já previa as ações de lealdade em seus estatutos e, portanto, a emenda de 2014 foi basicamente simbólica. O objetivo da reforma, claramente, é incentivar e recompensar os acionistas de longo prazo e promover essa modalidade de investimento e, consequentemente, reduzir a visão de curto prazo. Em companhias não listadas em bolsa, as ações com direito ao voto plural podem ser estabelecidas pelo estatuto com uma votação de maioria absoluta de $2 / 3$. Destaca-se que as ações com direito ao voto plural são menos comuns em companhias fechadas porque nessas há geralmente um acionista ou um grupo familiar titulares do poder de controle, e outros instrumentos não prescedendo-se neste momento, das ações de lealdade.

Não obstante a intenção dessas medidas, a mudança foi radicalmente criticada pelos proxy advisors e por parte dos investidores institucionais. Todavia, não podemos esquecer que alguns dos investidores institucionais que se opuseram à Lei Florange, como os "hedge funds Alliance Trust ou Vivendi, não estavam preocupados em debater estratégias que incentivem investimentos a longo prazo, mas, sim, em conseguir short term boosts nos preços das ações" $" 11$.

Além disso, a União Europeia não adotou regras gerais sobre os direitos de voto, possivelmente acreditando no argumento dos reguladores que o direito societário europeu é essencial para o desenvolvimento econômico. Mais especificamente, para a análise do presente trabalho, a

111 OLIVEIRA, 2017, p. 219. 
União Europeia regulou o voto plural em duas áreas. No contexto de uma aquisição, por exemplo, os direitos de voto desproporcionais são (podem ser) neutralizados pelas regras inovadoras da Thirteenth Directive ${ }^{112}$. Além disso, o Tribunal Europeu de Justiça discutiu frequentemente as "golden shares", as quais atribuem direitos de voto diferenciados ao Estado nas deliberações de certas matérias ${ }^{113}$. Esta é claramente uma aplicação peculiar de ações com diferentes direitos de voto. Nessas áreas, o legislador e os juízes europeus mostraram uma preocupação com os efeitos do voto plural no âmbito do poder de controle e da liberdade contratual.

O voto plural está longe de ser incomum na Europa Continental. De fato, quando disponíveis, eles são mais difundidos do que nos EUA, tanto por causa quanto por consequência das estruturas de propriedade concentrada prevalecentes nesta parte do mundo.

Os gráficos a seguir, elaborados com base no relatório Sherman\&Sterling ISS-ECGI, oferecem uma visão geral da situação em alguns países europeus e não europeus (a informação refere-se a 2007, com pequenas atualizações do autor sobre a Itália) ${ }^{114}$.

\footnotetext{
${ }^{112}$ L. ENRIQUES, R.J.; GILSON, A.M. Pacces. The Case for an Unbiased Takeover Law (With an Application to the European Union). In: Harvard Business Law Review, 2014. p. 118.

${ }^{113}$ Essa discussão sobre as "Golden Shares" se deram no âmbito das privatizações de algumas empresas estatais.

${ }^{114}$ Disponível em:

<https://ecgi.global/sites/default/files/working_papers/documents/SSRN-id2574236.pdf>. Acesso em: 01 set. 2018.
} 


\section{Figura 7}

\begin{tabular}{|l|c|c|}
\multicolumn{4}{|c|}{ Availability of different classes of shares } \\
\hline \multicolumn{1}{|c|}{ country } & multiple-voting shares & nonvoting shares \\
\hline Belgium & NO & NO \\
\hline Germany & NO & NO \\
\hline Denmark & YES & NO \\
\hline Finland & YES & YES \\
\hline France & YES & YES \\
\hline Greece & NO & NO \\
\hline Ireland & YES & YES \\
\hline Italy & YES & YES \\
\hline Luxembourg & NO & NO \\
\hline The Netherlands & YES & NO \\
\hline Poland & NO & NO \\
\hline Sweden & YES & NO \\
\hline Spain & NO & NO \\
\hline United Kingdom & YES & YES \\
\hline Australia & NO & YES \\
\hline Japan & YES & YES \\
\hline USA & YES & YES \\
\hline
\end{tabular}

Fonte: Disponível em: <https://ecgi.global/sites/default/files/working_papers/documents/SSRNid2574236.pdf>. Acesso em: 01 set. 2018.

\section{Figura 8:}

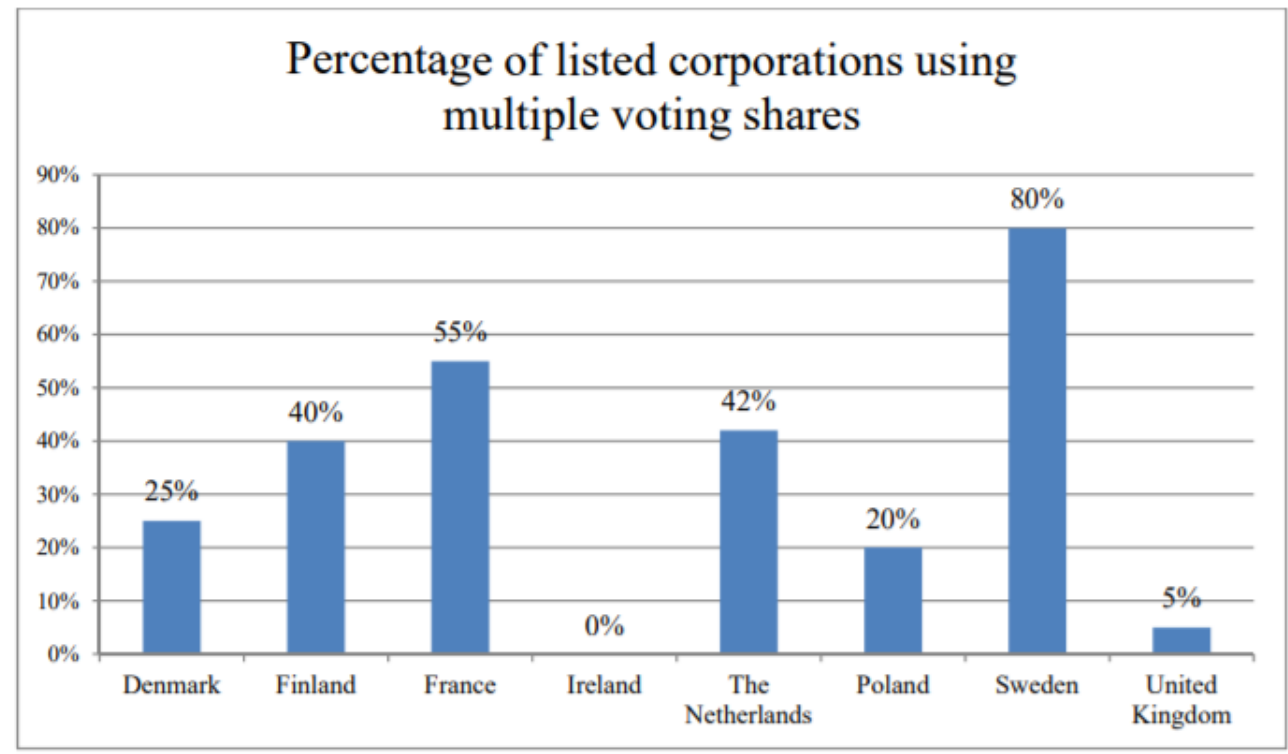

Fonte: Disponível em: <https://ecgi.global/sites/default/files/working_papers/documents/SSRNid2574236.pdf. >. Acesso em: 01 set. 2018.

\subsubsection{EUA}

Ainda que a maioria das companhias adotem, de certa forma, o princípio do "one share, one vote", a adoção de estruturas de classes 
distintas nos EUA é a regra aplicável de forma padrão. A regulação americana não estabelece limitações significativas à emissão de ações com direitos de voto diferenciados e concedem ampla flexibilidade. Como veremos, disposições mais rígidas podem ser encontradas nas regras de listagem promulgadas pelas bolsas de valores, e sua evolução representa um exemplo peculiar de competição regulatória. Considerar a experiência dos EUA é importante não só para as dimensões e relevância do mercado, mas também porque a maioria dos estudos empíricos realizados acerca do voto plural, e vários que servirão como parâmetro da legislação pátria, referemse aos EUA.

No início do século XX, o voto plural nos EUA já era amplamente usado. Similarmente a outros países, no entanto, após a década de 1920, provavelmente também devido à grande depressão, que foi responsável por afastar os pequenos investidores dos mercados financeiros. Em 1900, a grande maioria das companhias norte-americanas eram vinculadas ao princípio one share, one vote $e^{115}$. Os estatutos sociais das empresas estatais, no entanto, apenas estabeleceram o referido princípio como uma regra padrão. As demais companhias estavam livres para desviar do padrão estatutário, o que acabou sendo verificado na prática, em que um número crescente de companhias passou a não adotar o referido princípio. Muitas companhias, por exemplo, emitiram duas classes de ações ordinárias: uma com direitos totais de voto, com base no princípio de um voto por ação; a outra, sem direito a voto (mas com maiores direitos de dividendos) ${ }^{116}$.

Estes instrumentos tornaram-se cada vez mais criticados, em particular por alguns economistas conhecidos como William Z. Ripley, um professor de economia política de Harvard, que era o mais proeminente proponente da ideia de direitos de voto igualitários. Segundo Ripley, a ação não votante era a "crowning infamy" em uma série de desdobramentos

\footnotetext{
${ }^{115}$ STEVENS, W.H.S. Stockholders`Voting Rights and the Centralization of Voting Control. 40 Q. J. Econ. 1926. p. 353-354.

116 A. Dewing. The Financial Policy of Corporations. $5^{\mathrm{a}}$ ed. 1953. p. 163.
} 
destinados a privar os investidores de participar das decisões empresariais. Em essência, sua versão inicial acerca do conflito de interesses era que os sócios-fundadores se utilizavam de ações ordinárias sem direito a voto como mecanismo de manutenção do poder de controle ${ }^{117}$. Ao emitir as ações ordinárias com direito a voto para os sócios-fundadores e ações nãovotantes para os demais investidores, os sócios-fundadores conseguiam captar recursos consideráveis sem perder o controle da companhia.

Nesse contexto, a decisão de 1925 referente à abertura de capital da Dodge Brothers, Inc. é precisa: a Dodge vendeu um total de U\$ 130 milhões em (i) títulos de dívida (bonds), (ii) ações preferenciais e (iii) ações ordinárias sem direito a voto. A companhia era controlada, no entanto, por uma empresa de investimento bancário, que pagou U\$ 2,25 milhões por suas ações ordinárias com direito a voto ${ }^{118}$.

Em 1926, Ripley ${ }^{119}$ já havia declarado o desaparecimento de ações ordinárias sem direito a voto. Todavia, sua assertiva foi um tanto prematura: nos anos entre 1927 e 1932, pelo menos 288 companhias emitiram ações sem direito de voto ou com voto limitado (quase o mesmo número entre 1919 e 1926).

Esta batalha foi parcialmente bem-sucedida. A partir de 1940, a New York Stock Exchange (NYSE) não aceitava companhias que tinham ações sem direito a voto, e entre esse ano e o final da década de 1970, o número de emissores norte-americanos com estruturas duais de ações foi inferior a 40. Nesse sentido:

Without at this time attempting to formulate a definite policy, attention should be drawn to the fact that in the future the committee, in considering applications for the listing of securities, will give careful thought to the matter of voting control.

\footnotetext{
117 A.A.; G. Means, 1967, p. 75-76.

$118 \mathrm{O}$ debate sobre os efeitos negativos das ações com direitos de voto desproporcionais para os investidores foi tão intenso que, em 1926, o jornal progressista New York World publicou um poema curto e engraçado condenando o uso das ações sem direito a voto.

${ }^{119}$ W. Ripley. Main Street and Wall Street. Little, Brown and Company. Boston, 1927. p. 77.
} 
This policy gradually hardened, until the NYSE in 1940 formally announced a flat rule against listing nonvoting common stock ${ }^{120}$.

A partir dos anos oitenta, o boom de operações de fusões e aquisições e o receio de aquisições hostis em particular, reacenderam o interesse por esses (e outros) dispositivos de aprimoramento do controle. Nesse momento, a busca por regulamentos em prol da autonomia privada e maior liberdade contratual levou a um ambiente de competição entre as bolsas de valores.

Após várias décadas de um hiato acerca da controvérsia, a estrutura de classes duais de ações voltou a moda durante o início dos anos 80. Uma pesquisa subsequente descobriu que 37 de 44 companhias abertas adotaram ações com direitos de voto diferenciados entre 1962 e $1984^{121}$. Outras 34 companhias criaram estruturas de classes duais de capital entre março de 1986 e maio de 1987. É necessário, contudo, arguir que as razões que levaram a adoção desses mecanismos são distintas, de modo que se diferenciam pelos seguintes motivos: (i) motivação, (ii) modelo adotado e (iii) método de implementação.

O desejo de aumentar o capital próprio e, simultaneamente, manter o poder de controle nas mãos dos sócios-fundadores ou do grupo empresarial, motivaram muitos, senão a maioria, das ações com direitos de voto diferenciados criadas durante as cinco décadas desde primeira vez que a NYSE anunciou sua política.

Tradicionalmente, a NYSE e a American Stock Exchange (Amex) tinham limitações bastante restritas para os desvios do princípio do "one share, one vote" ${ }^{122}$. Grandes corporações, incluindo a General Motors, começaram a contemplar, e até mesmo tomar medidas preliminares, para abandonar a NYSE e se transferir para a National Association of Securities

\footnotetext{
${ }^{120}$ SELIGMAN, Joel. Equal Protection in Shareholder Voting Rights: The One Common Share, One Vote Controversy, 54 George Washington Law Review . p. 687-697, 1986.

${ }^{121}$ PARTCH, Megan. The Creation of a Class of Limited Voting Common Stock and Shareholder Wealth, 18 J. Fin. Econ., 1987. p. 313-314.

${ }^{122}$ A NASDAQ tinha um regulamento distinto.
} 
Dealers Automated Quotation System (NASDAQ), que tinha uma regulação mais liberal. Para evitar perder negócios, a NYSE e a Amex renderam-se à pressão competitiva e submeteram à SEC uma solicitação para modificar seus requisitos de listagem, permitindo as estruturas duais de ações.

Nesse contexto, a SEC não ficou satisfeita e, de fato, no final da década de 1980, introduziu a famosa Rule 19c-4. A rule 19c-4 alterou as regras de autorregulação das companhias (Self Regulatory Organizations SROS) para proibir que os valores mobiliários de uma companhia sejam listados em uma bolsa de valores nacional ou negociados na NASDAQ, caso a companhia tenha emitido títulos ou tenha tomado outras medidas societárias para anular, restringir ou reduzir de forma concreta os direitos de voto dos acionistas. Embora não seja expressamente o padrão conforme o princípio "one share, one vote", a rule 19c-4 impôs limitações substanciais à capacidade das companhias norte-americanas de adotar ações com direitos de voto diferenciados ${ }^{123}$.

A Business Roundtable (um poderoso lobby de CEOs de grandes companhias) imediatamente contestou essa regra no judiciário. A decisão (1990), resultante do caso Business Roundtable v. SEC, é fundamental no âmbito dos poderes regulatórios das agências federais, em que a United States Court of Appeals for the District of Columbia Circuit acabou derrubando a regra, adotando a visão de que a questão, que dizia respeito aos assuntos internos de uma companhia, não estava dentro da competência da SEC $^{124}$.

${ }^{123}$ BAINBRIDGE, Stephen M. The Short Life and Resurrection of SEC Rule 19C-4. In: Washington University Law Review. v. 69, Issue 2 In Memoriam: F. Hodge O'Neal. jan. 1991. Disponível em: <https://openscholarship.wustl.edu/law_lawreview/vol69/iss2/6/>. Acesso em: 14 out. 2018.

${ }^{124}$ G. M. Hayden; M. T. Bodie. One Share, One Vote and the False Promise of Shareholder Homogeneity. In: Cardozo Law Review. BUS. Roundtable v. SEC, 905 F. 2 d 406 (D.C. Cir. 1990), 2008. p. 471. Disponível em: 〈https://scholarlycommons.law.hofstra.edu/faculty_scholarship/40/>. Acesso em: 14 out. 2018. Cf. Decisão: [T]he [Securities] Exchange Act [of 1934] cannot be understood to include regulation of an issue that is so far beyond matters of disclosure (such as those disclosures required under $\$ 14$ of the Exchange Act), and of the management and practices of selfregulatory organizations, and that is concededly a part of corporate governance traditionally left to the states. 
Um compromisso foi rapidamente alcançado. A SEC convenceu as bolsas de valores, através da sua persuasão moral, a reintroduzirem limitações parciais ao voto plural. Hoje, as provisões, como a regra $\S$ 313.00 do NYSE Listed Company Manual, proíbem a emissão de nova classe de ações sob o regime de voto plural que venha a diminuir o poder de voto dos acionistas, mas fornecem várias exceções para a adoção do voto plural, bastante semelhantes às recentemente introduzidas na Itália, como destacado anteriormente. Nesse sentido, ações com voto plural podem ser emitidas: "(i) antes de um IPO; (ii) após a companhia ter realizado um IPO desde que tenham as mesmas características das ações já emitidas; (iii) respeitando a composição pré-existente do capital votante; e sob certas condições, em caso de aquisição" ${ }^{125}$.

Nesse contexto, vamos considerar brevemente como o voto plural típico funciona nos EUA. É claro que, embora os problemas econômicos subjacentes relacionados ao uso do voto plural sejam semelhantes em todo o mundo, existem diferenças regulatórias relevantes que merecem ser mencionadas. Nos EUA, geralmente duas classes de ações são emitidas: uma ação, com um voto por ação, similar às ações "ordinárias" (common stock) na Europa, vinculadas ao princípio proporcional "one share, one vote"; e ações B, que concedem mais votos por ação (geralmente 10). As ações B são emitidas para todos os acionistas como um dividendo; no entanto, se um acionista as transfere para terceiros, os privilégios do voto são perdidos (muitas vezes as transferências para os herdeiros dos titulares originais - fundadores da companhia - permitem manter os privilégios especiais do voto). A consequência é que em pouco tempo as ações B e seus votos se concentram nas mãos de acionistas interessados no poder de controle e com perspectiva de longo prazo, enquanto investidores institucionais e de varejo, que obviamente negociam as ações diariamente, perdem quase imediatamente o benefício dos direitos.

${ }^{125}$ MUSSNICH, Francisco Antunes Maciel. Voto Plural: Quebrando Paradigmas. Disponível em: <https://www.valor.com.br/legislacao/5228253/voto-plural-quebrando-paradigmas>. Acesso em: 28 out. 2018. 
A possibilidade de emissão de ações com voto plural ainda representa uma vantagem competitiva das bolsas de valores americanas. Podemos destacar aqui, por exemplo, o caso do time de futebol Manchester United, que em 2012 decidiu abrir seu capital, e optou pela bolsa de Nova York sobre a de Cingapura, usando como justificativa a possibilidade de a primeira permitir a companhia a emissão de ações com voto plural.

\subsection{Emissão de Ações com Voto Plural em IPOs}

\subsubsection{Casos Recentes (Google, Snapchat, Facebook e Alibaba)}

Um IPO é a operação que permite uma companhia acessar a poupança popular, por meio da oferta pública de suas ações ao mercado de capitais. É por meio da referida operação que um companhia consegue acessar uma nova base de investidores, que podem fornecer maior liquidez para suas ações. A companhia, ao perimtir que suas ações sejam negociadas publicamente no mercado, também fornece alguns sinais importantes e tendências com relação ao preço da ação; e à sua administração, no ambito de seu desempenho econômico e perspectivas futuras.

Além disso, um IPO que utiliza estruturas duais permite a continuação das normas de governança que existiam antes da abertura de capital $^{126}$. Tais normas, bem como seus efeitos quanto aos direitos dos acionistas, são bem descritos em uma declaração de Larry Page, em 2004, antes do IPO do Google, como segue:

In the transition to public ownership, we have set up a corporate structure that will make it harder for outside parties to take over or influence Google. This

\footnotetext{
${ }^{126}$ Vide Henn e Alexander: "Disproportionate voting, which is possible only where two or more classes (or series) are outstanding, exists when one class (series) of shares is validly given greater or less votes per share than another class (series). An example would be where one class (series) has normal voting rights and the shares of another class (series) carry multiple or fractional votes." HENN, Harry G. ALEXANDER, John R. Laws of Corporations. St. Paul, Minnesota: West Publishing Co. Third Edition, 1983. p. 499.
} 
structure will also make it easier for our management team to follow the long term, innovative approach emphasized earlier ${ }^{127}$.

Esta declaração elenca vários pontos essencias em relação às estruturas duais de ações. Primeiramente, o Google seria quase invulnerável às aquisições hostis de controle e aos potenciais benefícios que tais aquisições podem proporcionar, a menos que os titulares das ações com voto plural aprovem a operação.

Em segundo lugar, a companhia estaria invulnerável às ações dos hedge funds, no que se refere à possibilidade de eleição de membro do conselho de administração ou para votação da operação de aquisição de controle. Além disso, vale arguir acerca da capacidade dos hedge funds ativistas de aumentar significativamente o valor das ações de uma companhia alvo, o que permite alguns autores sustentarem que o ativismo dos hedge funds funciona como um mecanismo de correção na governança de uma companhia aberta ${ }^{128}$.

Ainda, depois de passar por várias seções de financiamento privado onde o universo de acionistas estava limitado a investidores qualificados, tentando maximizar o valor de seu investimento - a companhia, após o IPO, enfrenta um grupo muito mais diversificado de acionistas institucionais.

\footnotetext{
${ }^{127}$ Disponível em:

<https://www.sec.gov/Archives/edgar/data/1288776/000119312504073639/ds1.htm>. Acesso em: 30 set. 2018.

Disponível em: <https://perma.cc/6UF8-EB9B>. Acesso em: 29 set. 2018.

Ainda: "The main effect of this structure is likely to leave our team, especially Sergey [Brin] and me, with significant control over the company's decisions and fate, as Google shares change hands. New investors will fully share in Google's long term growth but will have less influence over its strategic decisions than they would at most public companies. While this structure is unusual for technology companies, it is common in the media business and has had a profound importance there. [...] Media observers frequently point out that dual class ownership has allowed these companies to concentrate on their core, long-term interest in serious news coverage, despite fluctuations in quarterly results. The Berkshire Hathaway company has applied the same structure, with similar beneficial effects. From the point of view of long-term success in advancing a company's core values, the structure has clearly been an advantage. Academic studies have shown that from a purely economic point of view, dual class structures have not harmed the share price of companies. The shares of each of our classes have identical economic rights and differ only as to voting rights".

${ }^{128}$ ROSE, Paul; SHARFMAN, Bernard S. Shareholder activism as a corrective mechanism in corporate governance. 2014 BYU L. REV. 1015, 1015 (2014). Disponível em: <https://digitalcommons.law.byu.edu/cgi/viewcontent.cgi?article=2943\&context=lawreview〉. Acesso em: 28 out. 2018.
} 
Isso inclui os que podem ser desinformados e nem sempre estão atuando com o objetivo de maximizar o lucro dos acionistas.

Além disso, os sócios-fundadores terão a possibilidade de implementar suas visões estratégicas sem sentir a pressão de realizar alterações só com base em seus resultados trimestrais que possam vir a desapontar os acionistas. A titulo de exemplo, podemos destacar o Facebook, de Mark Zuckerberg - que enfrentou muitas críticas em abril de 2012 - o qual decidiu comprar um aplicativo que tinha apenas 13 funcionários e nenhuma receita ${ }^{129}$. Essa aquisição ocorreu apenas um mês antes da companhia lançar seu IPO com uma estrutura de classes duais de ações. Conforme relatado, o então CEO do Facebook completou a aquisição antes mesmo de consultar o conselho de administração. Nesse contexto, o preço das ações do Facebook caiu de maneira drástica após seu IPO, acrescentando uma perda de $54 \%$ de seu valor após quatro meses de negociações no mercado ${ }^{130}$.

Em julho de 2015, os analistas ainda se questionavam se a referida aquisição geraria receita para o Facebook. Acontece que aquela aquisição era o Instagram, a subsidiária do Facebook, que atualmente pode valer até U\$ 25 bilhões a U\$ 35 bilhões, se não valor superior, e que gerou uma receita em torno de U\$ 3,92 bilhões em $2017^{131}$. Na ausência de uma estrutura de classes duais de ações que forneça a Mark Zuckerberg o controle do Facebook, o jovem CEO sentiu uma pressão trimestral para provar que ele tomou a decisão correta, talvez minando sua credibilidade

\footnotetext{
${ }^{129}$ ORESKOVIC, Alexei. Everyone thought Mark Zuckerberg was crazy to buy a 13-person app for \$1 billion - Now instagram looks like one of the most brilliant tech acquisitions ever made, bus. INSIDER. Disponível em: <http://www.businessinsider.com/instagram-zuckerbergs-biggestwin-so-far-2016-1>. Acesso em: 08 out. 2018.

${ }^{130}$ GALGANI, Matthew. A Tale of 4 IPOs: Facebook, Alibaba, Snap and Square. INV'S. Bus. Daily (Oct. 21, 2017). Disponível em: <http://www.investors.com/how-to-invest/investorscorner/a-tale-of-4-ipos-facebook-alibaba-snap-and-square/>. Acesso em: 14 out. 2018.

131 CHAYKOWSKI, Kathleen. Facebook Reports Strong First Quarter. Revenue, Earnings Beat Estimates. FORBES. Disponível em:

<https://www.forbes.com/sites/kathleenchaykowski/2017/05/03/facebook-shares-rise-on-firstquarter-revenue-that-beat-estimates/\#380a62106b6d>. Acesso em: 14 out. 2018.
} 
aos olhos de um conselho de administração independente, bem como sua autoridade gerencial e administrativa.

Nao há nenhuma pesquisa empírica no que se refere ao valor das estruturas de classes duais ${ }^{132}$. Como observado por Renée Adams e Daniel Ferreira: "because ownership structures are endogenous,” i.e., companies do not choose to use this structure based on some random process, "many difficulties arise in estimating the impact of disproportional ownership on firm and market outcomes" 133 .

Ou seja, quaisquer que sejam os resultados desse tipo de estudo, existe grande chance que eles sejam tendenciosos (a depender das premissas adotadas). Além disso, caso uma companhia que deseje abrir seu capital, adote uma estrutura classes distintas de ações, na tentativa de descobrir como ela iria performar financeiramente caso ela nao tivesse adotado tal estrutura, isto se tornaria um contrasenso. Isto é, nós nunca saberemos se o Google, Alibaba, Comcast Corporation e o Facebook teriam se saído melhor ou pior, caso nao adotassem as ações com direito a voto plural (super-voting stock). No entanto, sabemos que essas e outras companhias têm tido bastante sucesso com esse tipo de estrutura. Como afirmado por Fischel no contexto de companhias com ações de classes duais:

It is even possible that the market value of the shares of such firms would be higher if the family or founding entrepreneur would relinquish control. In this event, the family or entrepreneur is paying for its preference for control in the form of a higher cost of capital. Of course, the opposite can also be true. The market value of shares in a firm controlled by a family or founding entrepreneur may be higher if, for example, continuity of management is valued by investors

\footnotetext{
${ }^{132}$ GOSHEN, Zohar; SQUIRE, Richard. Principal Costs: A New Theory for Corporate Law and Governance. $n^{\circ}$ 117. Columbia Law. Rev., 2017. p. 815-16.

${ }^{133}$ ADAMS, Renee; FERREIRA, Daniel. One Share, One Vote: Empirical Evidence 3. European Corporate Governance Inst. Working Paper Series in Finance no. 177, 2007. Disponível em: <https://papers.ssrn.com/sol3/papers.cfm?abstract_id=987488>. Acesso em: 14 out. 2018.
} 
and there exist alternative governance mechanisms to align the interests of managers and investors ${ }^{134}$.

Adicionalmente, os dados mais significativos sobre IPOs com esse tipo de estrutura são relativamente novos e seria necessário aguardar mais tempo antes de ser analisado. Nessa perspectiva, a partir do IPO do Google em 2004 se iniciou uma tendência de IPOs de grande valor de mercado favorecendo as estruturas duais, o que pôde ser observado nos últimos anos. Os dados críticos ainda precisam ser incorporados à análise das estruturas duais. A existência de grandes companhias de alto valor de mercado com esse tipo de estrutura também sugere que a análise dos dados seria beneficiar algum tipo de ponderação de valor de mercado.

\subsubsection{Caso Snap Inc.}

Os investidores do mercado de ações têm estado muito dispostos a ignorar os potenciais problemas associados à estrutura de classes duais, a ponto de investir em companhias que adotam tal sistema, onde as ações ordinárias praticamente não têm direito a voto. Como exemplo, podemos citar o caso do Snapchat: a companhia Snap Inc. abriu capital em 2 de março de 2017 com três classes de ações em sua estrutura de capital: (i) Classe A - ações preferenciais (listadas na NYSE); (ii) Classe B - ações ordinárias com direito a voto (não listadas, detidas pela administração e investidores iniciais); e (iii) Classe C - ações com voto plural (super-voting stock) (não listadas, detidas pelos dois co-fundadores, com 10 votos por ação e representando 88,6\% das ações votantes da companhia).

Embora o Google e Under Armour também terem oferecido anteriormente ações sem direito a voto em ofertas públicas secundárias, o IPO da Snap Inc. foi o primeiro caso de um IPO com a oferta de ações desse tipo. Ainda assim, a oferta foi recebida pela comunidade de

\footnotetext{
${ }^{134}$ FISCHEL, Daniel R. Organized Exchanges and the Regulation of Dual Class Common Stock. In: University of Chicago Law Review. 1987. p. 136. Disponível em: <https://chicagounbound.uchicago.edu/journal_articles/1413/>. Acesso em: 14 out. 2018.
} 
investidores com grande entusiasmo, com ações da companhia sendo negociadas pelo preço de U\$ 17 por ação, dando-lhe uma valorização de mercado de cerca de U\$ 28,3 bilhões ${ }^{135}$.

Ainda mais importante, os investidores iniciais no IPO da Snap Inc. não eram investidores de fundos de índices passivos e desinformados - já que as ações sem direito a voto da companhia ainda não foram incluídas em um índice - mas eram principalmente investidores qualificados que podem ser classificados como "information traders"136. Essa definição está ligada ao investidor que está disposto e é capaz de dedicar recursos para coletar e analisar informações como base para suas decisões de investimento. Os information traders procuram diferenças entre o valor e o preço com base nas informações que eles possuem e depois negociam para capturar o valor de suas vantagens informacionais. Dada a ausência dos direitos de voto, devemos também esperar que os demais investidores sejam value investors (investidores de valor). Esses investidores são considerados uma categoria especial de information trader, que pode ser classificado como aquele que utiliza seu tempo, habilidade e recursos em prol do valorização de uma companhia e de seus valores mobiliários ${ }^{137}$ e, basicamente, faz com que outros acionistas se preocupem em participar mais ativamente do cotidiano societário da companhia, empreendendo seus esforços para obter o poder de controle ou investindo em recomendações sobre como corrigir as ineficiências gerenciais da companhia.

No caso específico da Snap Inc., a lista de value investors que compraram ações da companhia durante ou um pouco depois do IPO inclui dois fundos mútuos (mutual funds) administrados pela Blackrock Inc., um grande conselheiro desses tipos de fundos $(9,4$ milhões de ações adquiridas

\footnotetext{
${ }^{135}$ HIRSCH, Lauren. Snap's Shares Pop After Year's Biggest. In: IPO, Reuters. mar. 2, 2017. 01:06 am. Disponível em: 〈http://www.reuters.com/article/us-snap-ipo-idUSKBN1690I7〉. Acesso em: 27 out. 2018.

${ }^{136}$ GOSHEN, Zohar; PARCHOMOVSKY, Gideon. The Essential Role of Securities Regulation. 55 DUKE L.J. 711, 714. 2006.

${ }^{137}$ ROSE; SHARFMAN, 2014, p. 1033.
} 
no IPO da Snap Inc. $)^{138}$ Isto foi visto de um modo irônico pelo mercado em geral, uma vez que a equipe de administração de investimento da Blackrock Inc., que é a unidade responsável pelas questões de governança corporativa, teve uma postura muito ativa consoante às críticas de estruturas duais de ações.

Outros information traders que investiram em ações da Snap Inc. incluem: NBC Universal, uma unidade da Comcast Corp., que investiu U\$ 500 milhões (aproximadamente 29,4 milhões de ações) ${ }^{139}$, Third Point LLC (2,25 milhões de ações), Jana Partners LLC (550.000 ações), o banco de investimento Goldman Sachs Group, Inc. (1,1 milhão de ações) e grandes gestores de ativos, como Soros Fund Management, LLC (aproximadamente 1,7 milhões de ações) e Och-Ziff Capital Management (aproximadamente 1 milhão de ações) ${ }^{140}$.

Nessa perspectiva, um ponto a ser levantado é: por que os value investidors no IPO da Snap Inc. foram tão tolerantes em relação à governança corporativa da companhia, a qual permitiu a emissão de ações de classes distintas sem nenhum direito de voto e que, obviamente, levaria a um aumento nos custos de agência?

Há duas razões: a eficiência de maximização de riqueza que resulta de regras privadas de governança corporativa, e a compreensão de que os custos de agência não são os únicos custos de governança que precisam ser minimizados.

Uma compreensão das regras privadas de regulação se inicia com Michael Jensen e a famosa descrição de William Meckling de que uma

\footnotetext{
${ }^{138}$ ABLAN, Jennifer. et al., High-Profile Snap Stackholders Revealed in Filings. In: Reuters. may 12, 2017, 06:25 pm. Disponível em: <https://ca.reuters.com/article/technolo gyNews/idCAKBN18830X-OCATC>. Acesso em: 07 out. 2018.

RANDEWICH, Noel. Snap Surges After Wall Street Heavyweights Reveal Stakes. In: Reuters. Disponível em: 〈http://www.reuters.com/article/snap-stocks-idUSL2N1IH0XV〉. Acesso em: 27 out. 2018.

${ }^{139}$ LASHINSKY, Adam. Why NBC Universal Got In on Snap's IPO. In: Fortune, out. 27, 2018. Disponível em: <http://fortune.com/2017/03/06/why-nbc-universal-got-inon-snaps-ipo/> . Acesso em: 16 out. 2018.

${ }^{140}$ SHARFMAN, Bernard S. A Private Ordering Defense of a Company's Right to Use Dual Class Share Structures in IPOs. 63. In: Vill. L. Rev. 1. 2018.
} 
organização seria uma ficção legal que serve de conexão para um conjunto de relações contratuais entre indivíduos ${ }^{141}$. As relações formadas vão depender do resultado do processo de negociação que ocorre entre as partes contratantes. Este processo de barganha no contexto corporativo de regras de governança é referido como autorregulação.

A autorregulação é considerada eficiente e necessária porque permite a implementação de regras de governança corporativa orientadas para o mercado. Isto é, permite que os assuntos internos de cada companhia sejam adaptados a seus próprios atributos e qualidades, incluindo seu pessoal, cultura, maturidade como negócio e práticas de governança. Com efeito, as escolhas das regras de governança são o resultado da relação contratual que maximiza o valor entre os acionistas e a administração.

O acionista, na qualidade de beneficiário único dos fluxos de caixa gerados pela companhia, argumentaria que, por ser o menos protegido contratualmente, ele mereceria ter sua riqueza maximizada a fim de preencher as lacunas contidas no estatuto social da companhia ${ }^{142}$. Ou seja, ele é a parte mais vulnerável na relação corporativa, uma vez que ele assume o risco do negócio e será o único a sofrer os prejuízos advindos da companhia.

No âmbito do processo de negociação, surge a estrutura de classes duais. Novamente, por que os investidores que compram ações em um IPO voluntariamente iriam além das regras tidas como padrão da lei societária e deixariam o controle para os sócios-fundadores, especialmente quando se trata de ações sem direito a voto como no caso da Snap Inc.?

A resposta mais óbvia é a de que esse tipo de estrutura de classes de ações pode garantir uma continuidade (administrativa/gerencial) na companhia no sentido de que as regras estabelecidas pré-abertura de capital serão mantidas (por algum tempo) após o IPO.

\footnotetext{
141 JENSEN; MECKLING, 1976, p. 305-310.

142 BAINBRIDGE, Stephen M. Director Primacy: The Means and Ends of Corporate Governance. Univ. of California. Los Angeles School of Law Research Paper Series n 02-06. 2002.
} 
Cumpre ressaltar que na fase pré-abertura de capital, a companhia não gera um fluxo de caixa positivo suficiente para atender às suas necessidades de passar por várias rodadas de financiamento privado. Por exemplo, a Snap Inc. passou por várias rodadas de financiamento pré-IPO que começou com uma pequena quantidade de capital inicial fornecido pela Lightspeed Venture Partners em $2012^{143}$.

No caso específico do Snap Inc., durante cada rodada de novos financiamentos, a questão sobre se os sócios-fundadores manteriam o poder de controle da companhia era constantemente abordada. Assumindo que eles mantivessem o controle, esse foi o resultado dos investidores que forneceram financiamento privado de capital, concordando que o controle deveria ser detido pelos sócios-fundadores e que isso seria necessário para que a companhia se desenvolvesse e maximizasse o valor dos seus investimentos.

Os investidores que concordaram em ceder o poder de controle aos sócios-fundadores não são investidores desinformados quanto aos custos de agência que poderiam potencialmente surgir. Afinal, são investidores experientes capazes de negociar com os sócios-fundadores sobre o comando empresarial da companhia. Eles são, ou deveriam ser, os mais informados quando se trata de compreender a companhia em particular.

Este mesmo processo de negociação permanece quando chega o momento do IPO. Este processo requer que os investidores informados considerem o valor de ter um controle interno e os custos de participação acionária nas tomadas de decisões na companhia, e não apenas custos de agência.

Quando os sócios-fundadores possuem uma visão específica do rumo que a companhia deveria seguir, a necessidade de proteger esses membros é ainda maior. As estruturas de classes duais permitem que o empreendedor

\footnotetext{
${ }^{143}$ KONRAD, Alex. Snap's IPO Means a Huge Windfall for These VC Investors. In: FORBES. Disponivel em: <https://www.forbes.com/sites/alexkonrad/2017/02/02/snap-ipo-means-bigwindfall-for-early-snapchat-investors/\#285ed30ab414>. Acesso em: 16 out. 2018.
} 
implemente com capacidade máxima sua visão de negócios. Essa parece ser uma explicação do porquê dessa estrutura ter sido negociada na Snap Inc. (com Evan Spiegel e Robert Murphy) e também em companhias como a Berkshire Hathaway (Warren Buffet), Alphabet (Larry Page e Sergey Brin), Facebook (Mark Zuckerberg), Alibaba (Jack Ma) e Comcast (família Roberts).

De acordo com Zohar Goshen e Assaf Hamdani, o controle do voto permite ao empreendedor manter o controle sobre as decisões gerenciais para perseguir uma visao de negócios específica a fim de produzir retornos acima do mercado ${ }^{144}$. Portanto, em uma negociação resultante de um IPO, com o estabelecimento de classes duais, os acionistas estão manifestando sua compreensão de que a visão dos sócios-fundadores sobre o negócio precisa ser preservada e que a melhor maneira de minimizar os custos de agência é através da retenção do poder de controle pelos sócios-fundadores que possuem essa visão estratégica. A proteção desses membros mais do que compensa um aumento esperado nos custos de conflito de interesses.

Quando pensamos em termos de minimizar os custos totais do controle, torna-se mais fácil aceitar que, permitindo os benefícios particulares advindos do controle associado com as estruturas de classes duais, pode realmente ser um fator positivo para o valor da companhia a longo prazo. De acordo com Albert Choi ${ }^{145}$, quanto maiores os benefícios particulares do controle, maior a probabilidade do controlador estar preso à companhia a longo prazo e de se preocupar com o seu desempenho econômico.

Do ponto de vista dos participantes do mercado, a expectativa do aumento dos custos de agência ao longo do tempo é minimizada pela

\footnotetext{
${ }^{144}$ GOSHEN, Zohar; HAMDANI, Assaf. Corporate Control and Idiosyncratic Vision. n. 125. In: Yale Law Journal, 2016. p. 56. Disponível em:

<https://www.yalelawjournal.org/article/corporate-control-and-idiosyncratic-vision>. Acesso em: 16 out. 2018.

${ }^{145}$ CHOI, Albert H. Concentrated Control and Long-Term Shareholder Value. n. 8. In: Harvard Business Law Review. 2018. Disponível em: <http://www.hblr.org/wpcontent/uploads/2018/09/8.1-Choi.pdf>. Acesso em: 16 set. 2018.
} 
expectativa de que o potencial para o surgimento de habilidades de liderança e um desenvolvimento de valor significativo da companhia pode não ocorrer por muitos anos. Exemplo disso é o sucesso de longo prazo de Warren Buffett na Berkshire Hathaway, Brian Roberts na Comcast ou a LinkedIn que foi comprada pela Microsoft logo após seu IPO ${ }^{146}$.

Adicionalmente, a preocupação por esse desenvolvimento acelerado pode ser exagerada. De acordo com um estudo empírico recente ${ }^{147}$, nenhuma evidência foi encontrada quanto à relação entre as taxas de retorno das ações, a separação dos direitos de voto e os direitos de fluxo de caixa. Entretanto, o que se constatou foi que as companhias que adotam ações de classes duais tiveram uma taxa de retorno excedente ao longo de um período de quinze anos e que as empresas familiares que adotaram classe única e classes duais de ações com níveis semelhantes de controle apresentaram taxas de retorno similares.

É importante entender que, por um lado, excelentes argumentos podem ser fez feitos no sentido de que a adoção de estruturas de participação por meio de ações de classes duais deve seguir certas regras, como por exemplo, um prazo mínimo para adquirir o direito de voto plural ou um prazo de duração desses direitos. Por outro lado, não cabe aos acadêmicos e aos acionistas ativistas ditarem ao mercado de capitais a maneira como se deveria estruturar as regras de governança, uma vez que este contém participantes qualificados e que devem assumir o risco financeiro de investir nos IPOs. Obviamente, todo o investidor qualificado no mercado de capitais, que participa desse tipo de transação tem acesso a materiais acerca das estruturas de participação e podem se informar para o processo de negociação, sem que seja necessário a imposição de regras para regular o processo. Se, como resultado da negociação, a estrutura de classes duais não tiver um prazo de duração ou mesmo que não haja qualquer

${ }^{146}$ DIMITROV, Valentin; JAIN, Prem C. Recapitalization of One Class of Common Stock into Dual Class: Growth and Long-Run Stock Returns, 12 J. Corp. Fin. 342, 347. 2006.

${ }^{147}$ ANDERSON, Ronald et al., The Dual Class Premium: A Family Affair 29. In: Fox Sch. of Bus. Research Paper. $\mathrm{n}^{\circ}$. 17-021, 2017. 
direitode voto, podemos concluir que esses termos eram o que as partes entenderam como melhor prática para se concretizar o processo, assumindo e compreendendo os riscos da estrutura adotada.

Alguns podem argumentar que os direitos de voto desproporcionais são indesejáveis porque eles são inconsistentes com o princípio da democracia corporativa. Este argumento, no entanto, é fundamentalmente falho. Todas as companhias, incluindo grandes corporações, consistem em relações contratuais livremente assumidas por atores econômicos que querem maximizar o bem-estar da companhia. Quem pode exercer o direito de voto, e como e onde esse direito pode ser exercido são direitos que são normalmente atribuídos por contrato, no caso, o contrato de compra e venda de ações (com direitos específicos). Em contraste com as democracias governamentais - que geralmente são projetadas para servir metas mais amplas do que a maximização da riqueza - as regras de direito de voto para qualquer companhia em particular são aquelas que tentam maximizar seu valor. Dessa forma, conclui-se que o paternalismo ao mercado de capitais não é necessário quando se trata de IPOs com estruturas de classes duais.

\subsection{Princípio One Share, One Vote}

A importância investida no processo da democracia corporativa elevou as apostas para a construção do ambiente empresarial. Os direitos de voto diferenciados que dão a uma pequena minoria o poder desproporcional e os mecanismos utilizados para estabelecer essa relação estão sob crescente exame.

O princípio "one share, one vote" fornece um poderoso slogan para a governança corporativa e a proteção aos acionistas em nossa legislação societária. O princípio é atraente porque fornece um sistema de governança com base numa distribuição proporcional e equitativa: cada unidade de ações terá o mesmo poder de controle sobre a companhia. Nesse sentido, Lamy e Bulhões: 
Um dos princípios do regime legal das companhias é o de que o número de votos conferidos pelas ações é obrigatoriamente proporcional à participação no capital social. (...) a lei refere-se apenas ao número de ações, ao dispor, no artigo 110, que 'a cada ação ordinária corresponde 1 (um) voto nas deliberações da Assembleia Geral ${ }^{148}$.

O referido princípio tem sido descrito como a regra estatutária mais básica de votação no âmbito societário, bem como atreladas às instituições democráticas e à tradição liberal. Embora seja simplesmente uma regra padrão na maioria das jurisdições, a maioria das companhias abertas a adotaram, e continua sendo uma norma presumida. Entretanto, como já abordado anteriormente, esse princípio vem sendo questionado e alterado em algumas legislações pelo mundo, frente a nova realidade das companhias.

O princípio "one share, one vote" é consequência da demonstração de que os acionistas são quem tem mais interesse na maximização do valor da companhia, e o seu poder de voto deverá ser proporcional ao da sua participação no capital. De modo geral, a relação de proporcionalidade é uma maneira de assegurar que os acionistas tomarão decisões efetivas e apropriadas, uma vez que se trata do seu interesse maximizar o lucro da companhia.

O direito de voto é atribuído com a premissa de que os acionistas têm interesse em aumentar os lucros da companhia a longo prazo, dado que, gradativamente, eles são os beneficiários que recebem os lucros na forma de dividendos. Entretanto, se tratando de companhias abertas, em que os acionistas podem facilmente se retirar da companhia e não arcar com as consequências das suas decisões, haverá um risco maior ao fazerem propostas que, a longo prazo, não são lucrativas para a companhia. Além disso, cabe ressaltar a existência de ações preferenciais sem direito a voto ou outros instrumentos jurídicos empregados, como por exemplo, as poison

\footnotetext{
${ }^{148}$ MUSSNICH, Voto Plural: Quebrando Paradigmas, Acesso em: 28 out. 2018.
} 
pills ou os golden parachutes, formas já existentes que alteram a proporção do capital e do poder de voto.

Dessa forma, a realidade nos mostra que o princípio "one share, one vote" já deixou de prevalecer em muitas companhias, inclusive no âmbito nacional, o que torna a proibição do voto plural uma norma ultrapassada e meramente formal.

Um caso emblemático no Brasil envolvendo o confronto desse princípio é o da companhia Azul S.A. ("Azul"), no âmbito do Processo CVM n ${ }^{\circ} \mathrm{RJ}-2013 / 5993$, a qual teve seu pedido de registro inicial de emissor de valores mobiliários, categoria $\mathrm{A}$, em um primeiro momento negado pela SEP (área técnica da CVM), e, posteriormente obteve a reversão da decisão pelo colegiado da CVM.

O caso em tela trata exatamente do ponto aqui levantado: a desconstrução do princípio one share, one vote. A decisão da SEP indeferiu pedido apresentado pela Azul, por entender que as vantagens atribuídas às ações preferenciais infringiriam o disposto no art.15, $\S 2^{\circ}$ da LSA.

A SEP indeferiu o pedido da companhia por entender que:

[...] as vantagens atribuídas às ações preferenciais estariam em desacordo com o disposto no art.15, $\S 2^{\circ}$ da Lei $n^{\circ} 6.404 / 1976$. Para a área técnica, nos termos dos Relatórios de Análise ${ }^{\circ} 111$, de 15.10.2013 e ${ }^{\circ} 131$, de 12.11.2013, o referido dispositivo não trataria somente de uma proporção em termos de quantidade de ações, mas também de uma proporção em termos de aporte econômico. Consequentemente na visão da SEP, o poder político deveria guardar proporcionalidade com o volume de recursos aplicado no negócio, fato que não estaria sendo previsto no estatuto da Companhia. [...] A ideia é que o princípio "uma ação, um voto" alinha os interesses dos diferentes tipos de acionistas e mantém a proporcionalidade entre o poder político e o econômico ${ }^{149}$.

As reformas trazidas pela Lei $\mathrm{n}^{\circ} 10.303 / 01$, principalmente no que tange aos direitos políticos dos acionistas minoritários, foram inspiradas por esse movimento global do "one share, one vote" e de democracia societária. Por esse motivo, a área técnica concluiu que as ações preferenciais de

149 Disponível em: 〈http://www.cvm.gov.br/export/sites/cvm/decisoes/anexos/0010/8923-0.pdf〉. Acesso em: 04 nov. 2018. 
emissão da Azul, ao conferirem direitos econômicos 75 vezes superiores aos das ações ordinárias e, portanto, permitirem que o acionista controlador detenha o controle da Azul com uma parcela muito pequena do capital social, desrespeitariam o objetivo da lei, a qual pretendia estabelecer um equilíbrio entre direitos econômicos e políticos.

Entretanto, a LSA em seu art.15, $\S 2^{\circ}$, determina uma limitação ao numero total de ações sem direito de voto ou com voto restrito. Por outro lado, não há relação alguma entre a representatividade política e poder econômico, tanto é que a LSA abrange dividendos prioritários e preferenciais, com a possibilidade de distribuição desigual de lucros em ações de classes distintas. Isto sem falar da ausência de proibição da transposição de estruturas piramidais, através de holdings, como exposto no capítulo anterior.

A Diretora da CVM Ana Novaes apresentou voto em sentido contrário ao argumento exposto pela SEP e pela Procuradoria Especializada da CVM. No entendimento da Diretora, a LSA passou a reconhecer a dissociação entre os interesses políticos e econômicos, ao facultar a emissão de ações sem valor nominal e estabelecer que o limite percentual para emissão de ações preferenciais seria calculado com base no total de ações da companhia. Ainda, arguiu que potencial desencontro de interesses entre o acionista controlador e os minoritários deve ser devidamente julgado pelo mercado, sem prejuízo da fiscalização exercida pela CVM para apurar eventuais descumprimentos de deveres por parte de controladores e administradores ${ }^{150}$.

Ainda, no âmbito do mesmo processo, a Diretora Luciana Dias sustenta que:

Sendo as maneiras de dissociar direitos políticos e contribuição econômica tão diversas, é muito difícil para o regulador impedir ou coibir todas as formas que a dissociação entre direitos políticos e econômicos pode tomar porque há inúmeros

150 Disponível em: <http://www.cvm.gov.br/export/sites/cvm/decisoes/anexos/0010/8923-2.pdf〉. Acesso em: 04 nov. 2018. 
mecanismos para implementá-la e muitos deles têm múltiplas funções, sendo o desalinhamento apenas uma de suas externalidades, não necessariamente desejada pelas partes ${ }^{151}$.

O Colegiado acompanhou, por maioria, o voto da Diretora Ana Novaes e deferiu o recurso em favor da Azul, dando seguimento ao pedido de registro da companhia.

Ora, o que pretendo chamar a atenção aqui é que a lei societária brasileira, bem como sustentado pela Diretora da CVM Ana Novaes no processo da Azul, permitiu a dissociação entre os poderes econômicos e poderes políticos dos acionistas por meio de diversos mecanismos. Alguns autores, por outro lado, arguem no sentido de que esses mecanismos possibilitam a extração de benefícios particulares decorrentes do controle pelos acionistas controladores, e não estariam em alinhamento com a melhor prática de governança corporativa, uma vez que a proporcionalidade entre o capital investido e o poder político não se faria presente.

Entretanto, estar em um segmento de alta governança corporativa, como o Novo Mercado no Brasil, por exemplo, não é condição fundamental para o cumprimento deste objetivo, como bem mostra a prática do mercado. De outra forma, podemos encontrar companhias com estruturas que se desvinculam do princípio "one share, one vote" e que são avaliadas pelo mercado como companhias titulares de boa governança.

Como demonstrado, a estrutura da propriedade acionária das companhias (europeias, americanas e brasileiras) se alterou drasticamente. A crescente intervenção dos investidores institucionais diminuiu a relevância dos problemas de agência elencados por Berle e Means de dissociação entre a propriedade acionária e poder de comando empresarial. No entanto, ao mesmo tempo, ganhou espaço uma nova realidade: a

151 Disponível em: 〈http://www.cvm.gov.br/export/sites/cvm/decisoes/anexos/0010/8923-3.pdf〉. Acesso em: 04 nov. 2018. 
chamada separação "ownership for ownership"152. Nos dias de hoje, os investidores cada vez mais investem nas companhias por meio dos investidores institucionais.

A expansão dos investidores institucionais coincidiu com o aumento de lógicas de investimento a curto prazo e a ideia de que o investidor no mercado era fraco e inativo se alterou drasticamente com a crescente intervenção de investidores institucionais. Em um primeiro momento, essa atuação pode parecer benéfica, uma vez que estes investidores detém uma quantidade alta de ações e, consequentemente, podem influenciar nas decisões da companhia. Entretanto, a governança corporativa é constituída com base nos deveres fiduciários dos administradores para com a companhia e com os investidores. Ora, esse modelo esquece de analisar quem são os agentes que financiam os investidores institucionais.

Com efeito, o surgimento dos hedge funds e dos fundos de pensão deu ensejo à mediação da propriedade das participações no capital, que criou um conjunto de conflitos de agência horizontais ${ }^{153}$, dentre os quais se assentam entre os próprios investidores. A verdade é que, em grande parte, quem exerce o direito de voto nem sempre são os verdadeiros proprietários das ações. Os hedge funds são investidores de curto prazo que, por vezes, alteram a totalidade de seu portfólio três vezes por ano. Como sustentam Kahan e Rock, os hedge funds são o modelo de investidor de curto prazo, de tal forma que, para alguns fundos, um investimento que dure um dia é considerado um investimento de longo prazo ${ }^{154}$.

\footnotetext{
152 STRINE Jr., Leo E. Why excessive risk-taking is not unexpected. New York Times. Oct. 5, 2009. Disponível em: <https://dealbook.nytimes.com/2009/10/05/dealbook-dialogue-leo-strine/>. Acesso em: 10 nov. 2018.

153 RODRIGUES, Usha. Corporate Governance in an age of separation of ownership for ownership. In: Minnesota Law Review. v. 95 1822-1866, 2011. p. 1828ss. Disponível em: <https://papers.ssrn.com/sol3/papers.cfm?abstract_id=1736611>. Acesso em: 21 out. 2018.

${ }^{154}$ KAHAN, Marcel; ROCK, Edward. Hedge Funds in corporate governance \& corporate control. In: University of Pennsylvania Law Review. v. 155, 2017. p. 1021. Disponível em: <https://papers.ssrn.com/sol3/papers.cfm?abstract_id=1291580>. Acesso em: 21 out. 2018.
} 
Portanto, a realidade dos investidores institucionais demonstra claramente que o direito de voto é exercido, muitas vezes, por acionistas que não tem o menor interesse na saúde financeira da companhia.

Frente a essa realidade, a proibição pura e ausência de discussão no que se refere às ações de voto plural, a qual se baseia no princípio de que a cada ação deve corresponder a um voto, me parece equivocada, de modo que o referido princípio nem sempre merece vigorar, a depender da realidade econômica da companhia, ficando a critério dessa, de seus acionistas e do mercado em geral a introdução desse tipo de mecanismo em seu estatuto e na vida cotidiana societária da companhia.

\subsection{Voto plural no Brasil}

No Brasil, o Decreto n 21.536, de junho de 1932, não autorizou o instituto do voto plural, conforme dispõe o $\S 4^{\circ}$, do art. $1^{\circ}$ da referida norma ${ }^{155}$. No entanto, somente possibilitou as sociedades anônimas emitirem ações preferenciais, na forma de seu art.1: "O capital das sociedades anônimas pode ser, em parte, constituído por ações preferenciais de uma ou mais classes, observadas as disposições do presente decreto" 156 .

Ainda que como excepcionalidade ao princípio do one share, one vote, a LSA permitiu às companhias a possiblidade de emissão de ações preferenciais sem direito a voto, o que, de certa forma, , seria uma afronta ao referido princípio e à proporcionalidade entre o capital investido e o direito de voto. Além disso, conforme demonstrado neste trabalho, nao é apenas a possibilidade de emissão de ações preferenciais sem direito a voto que a LSA exepciona o referido princípio, podendo, dessa forma, ser encontrado em diversos outros dispositivos.Conforme exposto acima, o direito societário pátrio adotou a partir do Decreto-Lei $\mathrm{n}^{\mathbf{0}} 2.627$, em seu

\footnotetext{
$155 \S 4^{\circ}$ É vedado o voto plural.

156 Disponível em: < http://www2.camara.leg.br/legin/fed/decret/1930-1939/decreto-21536-15junho-1932-517361-publicacaooriginal-1-pe.html>. Acesso em: 05 nov.2018
} 
artigo $80^{157}$, o princípio do one share, one vote. Tal princípio foi consagrado e consubstanciado na LSA em seu art.110. Entretanto, com o desenvolvimento econômico e do mercado de capitais, as estruturas e os instrumentos jurídicos que permeiam a relação da participação econômica e do poder político no âmbito das sociedades anônimas foi modificado ao longo do tempo.

Como citado anteriormente, já existe no Direito Brasileiro uma dissociação entre poder político e poder econômico. $\mathrm{O}$ art. $110, \S 1^{\circ}$, da LSA, admite a limitação do número de votos por acionistas para, por exemplo, manter a companhia com capital pulverizado, impedindo a aquisição de controle de forma progressiva. Ora, o que é a limitação de votos por acionistas, senão a negação do referido princípio. A doutrina brasileira apenas repete o texto legal, nao enfrentando o tema propriamente dito, mesmo diante de uma realidade econômica que, por obvio, demanda nova reflexão acerca do voto plural. Nesse sentido, vale citar a lição de Nelson Eizirik: "[o] conceito de 'one share, one vote' está comecando a apresentar sinais de enfraquecimento, em razao do sucesso de companhias que adotam o voto plural"158.

Segundo Mussnich:

Relativizar o princípio do 'one share, one vote', não é ameaça se inserido com ressalvas, levando-se em consideração o atual cenário econômico brasileiro, em que as práticas do bom governo corporativo estão muito mais consolidadas e oferecem inúmeros instrumentos e remédios para proteger os acionistas minoritários investidores.

Atualmente, o que podemos observar é uma completa incompatibilidade desse princípio, adotado como regra geral, com a realidade econômica e social. Cabe aqui sustentar que não há cabimento para - devendo ser afastado - qualquer noção fundada em concepções

157 Decreto-Lei no 2.627/1940 - Art. 80. A cada ação comum ou ordinária corresponde um voto nas deliberações da assembleia geral, podendo os estatutos, entretanto, estabelecer limitações ao número de votos de cada acionista. Parágrafo único. É vedado o voto plural. (Revogado pela LSA).

${ }^{158}$ EIZIRIK, Nelson. A lei das S.A.., v. 2. 2ªd. Sao Paulo: Quartier Latin, 2015. p. 176 
"democráticas" do direito societário, que não tem qualquer embasamento teórico e não oferece qualquer utilidade se aplicado à realidade econômica. Tais convicções não merecem prosperar, sendo certo que o equivalente a esse conceito seria que a existência de um acionista controlador definido seria negativa para a companhia. Como trata a Teoria da Agência ${ }^{159}$, o acionista controlador com participação no capital menor que $100 \%$ terá mais incentivos para extrair benefícios particulares quanto menor seja sua participação na companhia.

No entanto, as situações de extração de benefícios particulares independem de quem detenha o poder de controle, seja um acionista ou a administração da companhia. Assim sendo, não podemos refusar a existência de um poder de controle, devendo, sim, enfrentar o potencial para expropriação de benefícios particulares através de normas que realmente reprimam tais exageros e que sejam cumpridas.

Por fim, sustenta Manoel Vargas:

\begin{abstract}
A argumentação de risco de abuso ou desproporção entre poder político e econômico não pode ser manifestada em abstrato, na opinião deste autor, sob pena de transformar-se em articulação destituída de bases plausíveis, contra o novo, o criativo, que objetiva, dentro de balizas lícitas, pois não vedadas em lei, realiar concretamente a orientação geral manifestada na exposição de motivos da lei das sociedades anônimas "de ampliar a liberdade do empresário privado nacional na organização da estrutura de capitalização da sua empresa ${ }^{160}$.
\end{abstract}

\title{
4.6. Projeto de Lei $\mathrm{n}^{0} \mathbf{1 0 . 7 3 6 / 2 0 1 8 ^ { 1 6 1 }}$ (Anexo I)
}

O presente projeto de Lei, que está para ser analisado no Congresso Nacional, visa instituir o voto plural no Brasil, com intuito de permitir a companhia fechada emitir ações com voto plural, por um prazo máximo de 3 anos, permitida uma única prorrogação por prazo igual, alterando-se, portanto, o art. 110 da LSA. Ainda, na nova redação do referido artigo,

\footnotetext{
159 JENSEN; MECKLING, 1976, p. 4-9.

${ }^{160}$ PUC-Rio. Departamento de Direito, 2017. p. 161.

${ }^{161}$ Disponível em:

$\langle$ http://www.camara.gov.br/proposicoesWeb/prop_mostrarintegra?codteor=1680750〉. Acesso em: 22 set. 2018.
} 
permite que a companhia que tenha seus valores mobiliários negociados em bolsa de valores ou em mercado de balcão organizado, confira o voto plural à uma única classe de ações, com o prazo de duração conforme disposto nos parágrafos anteriores.

Inicialmente, faz-se necessário tecer alguns comentários acerca das vantagens do voto plural, tomando como base as mudanças legislativas recentes em alguns países, conforme demonstrado neste trabalho. Dentre as vantagens, são comumente listadas: (i) continuidade na direção e estabilidade da condução empresarial, a fim de seguir um plano de negócios; (ii) atratividade ao mercado de capitais; e (iii) intuitus personae.

A primeira das vantagens das ações de voto plural é assegurar aos sócios-fundadores a continuidade de sua influência na administração e na condução dos negócios da companhia. Não é, porém, somente para os sócios-fundadores o benefício dessa continuidade. O benefício é ainda maior para a própria companhia, pois, na realidade o efeito produzido é garantir a estabilidade da administração e a comunidade de sua orientação, pondo a salvo das maiorias transitórias.

A geração atual é pautada pela inovação e pela iniciativa empresarial, o que, de certa forma, privilegia a figura do empreendedor como realizador de negócios. O mercado de capitais é e deve ser compreendido como um mecanismo de impulsão de investimentos e de alta atratividade por parte desses empreendedores. O que nos faz pensar sobre as diferentes formas de se estabelecer a relação entre os sócios-fundadores de uma companhia com (i) os stakeholders e (ii) o capital a ser investido em novos projetos e nos planos de negócios a longo prazo. Assim, entende-se que o Brasil deve caminhar no mesmo sentido das legislações aqui tratadas, no sentido de inovar e permitir novos arranjos societários, com intuito de promover o desenvolvimento e atratividade ao mercado de capitais. 
Ainda, os defensores do voto plural alegam que esse instituto, atribuindo maior poder a determinadas ações, acaba estabelecendo uma predominância de parcelas inferiores de capital, a qual redundaria, afinal, no predomínio das pessoas, em vez do capital, na companhia. Assim, sua administração pode ser atribuída a certas personalidades, não em razão do capital de que disponham, mas do valor da sua capacidade, sendo esse o beneficio para o intuitus personae.

Seguindo nessa linha, não podemos ignorar que a introdução de ações com voto plural poderá ocasionar alguns problemas em companhias em que já existem ações com direitos diferenciados, ainda que diferentes categorias das com voto plural. A emissão de ações com voto plural numa companhia onde até então só existiam ações ordinárias não desequilibra as relações de poder existentes entre os acionistas, uma vez que todos os sócios gozam de direito de preferência na mesma proporção da sua participação. Pelo contrário, no caso de companhias que já possuem outras classes de ações com direitos diferenciados, o direito de preferência não será uma forma de evitar alterações da estrutura da companhia se façam em prejuízo de alguns acionistas, podendo, para tanto, potencializar essa alteração das relações de poder. De fato, os acionistas não se encontram em pé de igualdade. A sua influência na estrutura societária dependerá, em grande parte, dos direitos de sua titularidade.

Ora, a criação de novas classes de ações com direitos diferenciados equivalentes ou superiores aos já existentes leva a um prejuízo indireto dos acionistas privilegiados que deverá ser tido como relevante no preenchimento das condições previstas no arts. 17 e 18 da LSA, que exige que, nesses casos, esses acionistas deem o seu consentimento à alteração, em assembleia especial dos acionistas titulares de ações dessa categoria. Esta solução tem por base a consideração de que os direitos diferenciados são condições das quais os acionistas fizeram depender a sua decisão de 
entrada ou de permanência na companhia, correspondendo à verdadeira "vontade fundacional"162.

Assim, em termos práticos, a introdução de classes de ações com voto plural no estatuto social da companhia, naquelas companhias que já apresentam outras ações privilegiadas, terá de passar por uma dupla avaliação: (i) maioria exigida para as alterações estatutárias; e (ii) aprovação em assembleia especial dos acionistas titulares das ações das classes indiretamente prejudicadas pela deliberação (art.136, § $\left.1^{\circ} \mathrm{LSA}\right)^{163}$.

Conforme sustenta Paulo Cunha ${ }^{164}$, a introdução desses direitos "é mera consequência da participação na sociedade, sendo [estes direitos] admissiveis desde que se processem com o respeito dos valores fundamentais do ordenamento jurídico e designamente da boa-fê". Partindo dessa premissa, cabe questionar se a introdução dessa classe de ação violaria o princípio da igualdade de tratamento dos sócios. Sabe-se, entretanto, que o referido princípio não é classificado como princípio de ordem pública, podendo, portanto, ser suprimido pela vontade das partes, como veremos a seguir.

Em primeiro lugar, quando a criação dessa nova classe de ações for feita via aumento de capital, os atuais acionistas terão direito de preferência (art.171 LSA) ${ }^{165}$, que assegura que a potencial diluição da sua participação é acompanhada por uma contrapartida que lhes permite obstar essa diluição, com regras específicas sobre a forma como se processa ${ }^{166}$. Dessa forma,

\footnotetext{
162 GONCALVEZ, Diogo Costa. Direitos especiais e o direito de exoneração em sede de fusão. $\mathrm{O}$ Direito, 2006. II, p. 313-362 (318).

${ }^{163}$ Art. 136. É necessária a aprovação de acionistas que representem metade, no mínimo, das ações com direito a voto, se maior quorum não for exigido pelo estatuto da companhia cujas ações não estejam admitidas à negociação em bolsa ou no mercado de balcão, para deliberação sobre: [...] § $1^{\circ}$ Nos casos dos incisos I e II, a eficácia da deliberação depende de prévia aprovação ou da ratificação, em prazo improrrogável de um ano, por titulares de mais da metade de cada classe de ações preferenciais prejudicadas, reunidos em assembleia especial convocada pelos administradores e instalada com as formalidades desta Lei.

${ }^{164}$ CUNHA, Paulo Olavo. Direito das sociedades comerciais. $5^{\circ}$ ed. Coimbra, 2005. p. 186.

${ }^{165}$ Art. 171. Na proporção do número de ações que possuírem, os acionistas terão preferência para a subscrição do aumento de capital.

${ }^{166}$ Caso a deliberação seja tomada com o propósito de satisfazer o interesse de alguns acionistas, a deliberação poderá ser anulada, alegando-se abuso de poder.
} 
fica assegurada a tutela e a igualdade dos acionistas cujas ações que sofreram prejuízos em razão dos direitos conferidos às novas ações.

Além disso, Mussnich entende não ensejar direito de recesso com a criação de ações com voto plural. O direito de recesso, disposto no art. 137 e 109, inciso V, da LSA, é o direito do acionista dissentir de determinada matéria deliberada em sede de assembleia geral (numerus clausus), na qual deixa de fazer parte da companhia, recebendo, em troca, o reembolso do valor de suas ações ${ }^{167}$.

Nesse sentido, Norma Parente ${ }^{168}$ salienta:

Assim, a lei dá aos acionistas controladores poderes para aprovar determinadas medidas que afetam substancialmente o direito do acionista minoritário, mas nesses casos, para manter equilíbrio entre o poder assegurado à maioria dos acionistas para dirigir a sociedade e a minoria acionária, sujeita a seu arbítrio, a lei assegura ao acionista o direito individual e sagrado de se retirar da sociedade, mediante reembolso do valor de suas ações.

Ora, no caso da introdução de classes de ações com voto plural durante a existência da companhia, não se verifica uma situação em que os propósitos em que se constituiu a companhia se desapareçam de forma a que se torne incompatível a manutenção do acionista dissidente na companhia.

Pelo contrário, não podemos esquecer que o direito de recesso é uma forma de tutelar direitos dos acionistas. Por isso, e também por implicar um esforço financeiro por parte da companhia no pagamento do reembolso, o direito de recesso deverá ser encarado como última ratio. Portanto, uma vez encontrada uma solução para a tutela dos direitos dos acionistas que seja menos onerosa - para os acionistas e para a companhia - é essa que deve ser adotada.

Segundo Mussnich, na justificação do Projeto de Lei:

\footnotetext{
${ }^{167}$ LAMY FILHO et al., 2017, p. 240.

168 PARENTE, Norma Jonssen. O Direito de Recesso na Incorporação, Fusão ou Cisão de Sociedades. In: Revista de Direito Mercantil, Industrial, Econômico e Financeiro. São Paulo, Ano XXXIV, n. 97, p. 67-75, jan/mar. 1995.
} 
De fato, a atribuição de voto plural a uma classe de ações configura estratégia com elevado potencial de incentivar a listagem em bolsa de companhias familiares e start-ups. Isso porque, essas são companhias cujo capital reputacional está, em regra, intimamente ligado a um fundador ou empreendedor. Atribuir-lhes voto plural é assegurar que acionistas-chave preservarão seu poder de controle, no cenário pós-abertura de capital, o que gera confiança - tanto para os demais acionistas quanto para potenciais investidores - na continuidade do padrão gerencial da companhia ${ }^{169}$.

Pelas razões aqui expostas, ao contrário de seguirmos na linha de extinção das ações com voto plural, esse mecanismo merece ter sua função reconsiderada, especialmente em razão do novo contexto econômico que se encontra o mundo atual e diante do inegável desenvolvimento de tecnologias e do mercado de capitais de maneira ampla.

${ }^{169}$ Anexo I. 


\section{CONCLUSÃO}

Buscamos aqui compreender dois mecanismos específicos que são constantemente utilizados pelas companhias a fim de captar recursos no mercado de capitais, mas, ao mesmo tempo, não se desvinculando do poder de controle exercido no âmbito interno da companhia. Para isso, fez-se necessário discutir o conceito de poder de controle estabelecido pela LSA e suas principais modalidades: (i) controle totalitário, (ii) controle majoritário, (iii) controle minoritário e (iv) controle gerencial.

Em sequência, analisamos os fatores históricos e regulatórios que levaram a um ambiente de dispersão acionária no mercado de capitais de países desenvolvidos como os EUA e o Reino Unido.

Como visto, no Brasil sempre prevaleceu um ambiente de alta concentração de capital na mão de poucos acionistas, tendo suas principais companhias um controle definido e com um acionista titular de maioria das ações com direito a voto, podendo, para tanto, exercer o poder de controle sem problemas.

Não obstante a dispersão acionária no mercado de capitais brasileiro ainda se encontrar em estágio inicial em comparação com os mercados mais desenvolvidos do mundo, não podemos deixar de destacar que este último apresentou, após as alterações legislativas supracitadas e a criação de segmentos especiais de governança corporativa (Nível 1, Nível 2 e Novo Mercado), uma mudança relevante em relação às companhias com capital acionário disperso. Contudo, conforme demonstrado nos estudos mencionados ao longo deste trabalho, as companhias sem controlador definido ainda são minoria no mercado de capitais brasileiro.

No entendimento da doutrina especializada, as normas que regulam a proteção aos investidores e as formas de organização da atividade empresária são resposáveis por determinar a estrutura de capital predominante em cada local. Ao longo desta monografia, constatou-se que 
uma série de normas jurídicas contribuiram para o modelo concentrado brasileiro. Trata-se dos mecanismos de dissociação entre o poder econômico e o poder político na companhia. Conforme demonstrado, tais mecanismos têm como funções a (i) potencialização do poder de controle e (ii) a proteção do seu titular.

Não há unanimidade quanto aos mecanismos de dissociação entre o poder econômico e o poder político dos acionistas. A ênfase deste trabalho foi na compreenção de dois institutos específicos: (i) as estruturas piramidais e (ii) as classes duais de ações (com destaque nas ações com voto plural).

A relação entre o acionista controlador e os acionistas minoritários é uma relação complexa que envolve uma multiplicidade de interesses (convergentes e divergentes). É certo que a governança interna, de maneira geral, é reconhecida pelo mercado, que julga as práticas associadas a boa governança fundamentais para a geração de valor e o desenvolvimento econômico da companhia.

Por essa razão, esses mecanismos são de extrema importância. Apesar de alguns autores sustentarem que tais mecanismos não são condizentes com a boa governança, a realidade dos fatos demonstra que essa assertiva deve ser afastada. As companhias listadas no segmento do Novo Mercado, por exemplo, são praticantes da melhor governança e um percentual significativo delas adotam as estruturas piramidais como estrutura de controle. Além disso, restou claro que as estruturas piramidais, por meio da cadeia vertical de holdings, podem ser consideradas mecanismos legítimos de alavancagem financeira e de manutenção do poder de controle. Os exemplos citados neste trabalho demonstraram que por meio das estruturas piramidais, a companhia tem acesso ao fluxo de caixa da companhia controlada com custos inferiores aos de uma participação direta. É necessário, contudo, esclarecer que essas estruturas merecem uma atenção especial, uma vez que, mal utilizadas, podem levar à 
expropriação dos acionistas minoritários, à perpetuação do poder de controle e a custos relativos ao conflito de interesses existente entre companhia controladora e suas controladas. Frisa-se, portanto, que apesar de ser permitido no direito brasileiro, este instituto precisa ser adotado com a devida transparência aos acionistas, respeitando as obrigações legais e as normas dos respectivos segmentos da bolsa de valores.

Em sequência, analisamos as estruturas duais de açöes, em especial, as ações com voto plural, no âmbito do direito comparado e observamos as recentes mudanças legislativas em países europeus e nos EUA.

Consideramos os exemplos de grandes companhias que adotaram o referido instituto e explanamos a importância de se ter um dispositivo relevante com respeito à atratividade ao mercado de capitais e à visão de investimento a longo prazo. Diante do recente sucesso de companhias que adotaram tal mecanismo, a tese de que a dissociação entre a representativadade política e a participação econômica ensejaria uma perda no valor da companhia e um grau elevado de extração de benefícios decorrentes do controle não merece prosperar. Ainda, merece destaque a explanação aqui realizada a respeito das ações com voto plural nos recentes IPOs. Assim, os países que tendem a permitir esse instituto adotam uma visão de que os sócios-fundadores merecem um tratamento especial e podem, a critério da assembleia geral, estabelecer direitos distintos dos demais acionistas quanto aos direitos de voto.

Adicionalmente, tratamos do tema no direito pátrio e foram feitas as considerações necessárias acerca da LSA e os respectivos marcos regulatórios responsáveis pela estrutura de propriedade predominante no mercado brasileiro e pelo tratamento do direito de voto dos acionistas.

Finalmente, foram feitos comentários sobre o Projeto de Lei $\mathrm{n}^{\circ}$ 10.736, em tramitação na Câmara dos Deputados, e suas possíveis alterações na LSA e impactos no mercado de capitais brasileiro. 
As expectativas do desenvolvimento da economia e a consolidação do papel das instituições poderiam encontrar um impulsionador em mecanismos como o voto plural. Este, por sua vez, permite que um empreendedor ou sócio-fundador vá até o mercado de capitais e o enxergue como um ambiente favorável à realização de negócios e de investimento, sem que este se desfaça do poder de controle da companhia. Após as considerações feitas durante este trabalho, conclui-se que a utilização séria e refletida do voto plural, com vantagens econômicas e políticas legítimas, pode significar uma oportunidade de atração ao mercado de capitais para aquelas empresas que pensam em angariar recursos, mas ao mesmo tempo, não estão dispostas a perder o controle da companhia (em uma possível diluição) e está vinculada à execução de um plano de negócios de longo prazo. Abusos e práticas não equitativas, certamente, devem ser reprimidas, no entanto, não por meio da restrição de soluções que cerceiam, de forma paternalista, a flexibilidade do mercado na estruturação de mecanismos de investimento e, sim pelo devido respeito à lei e às responsabilidades por ela previstas. 


\section{REFERÊNCIAS BIBLIOGRÁFICAS}

A. Dewing. The Financial Policy of Corporations.. $5^{\mathrm{a}}$ ed. 1953.

A.A. Berle Jr.; G. Means. The Modern Corporation and Private Property. Nova Iorque: Ed. Revista, 1967.

ABLAN, Jennifer. et al., High-Profile Snap Stackholders Revealed in Filings. In: Reuters. may 12, 2017. Disponível em: $<$ https://ca.reuters.com/article/technologyNews/idCAKBN18830X-

OCATC>. Acesso em: 07out. 2018.

High-Profile Snap Stackholders Revealed in Filings. In: Reuters. may 12, 2017, 06:25 pm. Disponível em: $<$ https://ca.reuters.com/article/technolo gyNews/idCAKBN18830XOCATC>. Acesso em: 07 out. 2018.

ADAMEK, Marcelo Vieira Von (Coord.). Temas de Direito Societário e Empresarial Contemporâneos. PC Editorial Ltda., 2011.

ADAMS, Renee; FERREIRA, Daniel. One Share, One Vote: Empirical Evidence 3. European Corporate Governance Inst. Working Paper Series in Finance no. 177, 2007. Disponível em:

<https://papers.ssrn.com/sol3/papers.cfm?abstract_ _id=987488>. Acesso em: 14 out. 2018 .

ALDRIGHI, Dante M.; MAZZER NETO, Roberto. Evidências sobre as Estruturas de Propriedade de Capital e de Voto das Empresas de Capital Aberto no Brasil. In Rev. Bras. Econ. vol. 61, n. 2, Rio de Janeiro, abril/jun., 2007. Disponível em:

<http://www.scielo.br/pdf/rbe/v61n2/a01v61n2.pdf>. Acesso em: 22 set. 2018.

; POSTALI, Fernando A. S. Propriedade Piramidal das Empresas no Brasil. In: Revista Economia, Brasilia, v. 12, nº 1, jan/abr/2011.

ANDERSON, Ronald et al., The Dual Class Premium: A Family Affair 29. In: Fox Sch. of Bus. Research Paper. n. 17-021, 2017.

ANTÓNIO, Nelson dos S.. Estratégia Organizacional - Do Posicionamento ao Movimento. $2^{\mathrm{a}}$ ed. Lisboa: Edições Silabo, 2006. 
AZEVEDO, Luís André N. de Moura. Controle Minoritário: Dissociação entre Voto e Participação Econômica na Companhia Aberta - Coleção IDSA de Direito Societário e Mercado de Capitais. v. 8. São Paulo: Quartier Latin, 2017.

BAINBRIDGE, Stephen M. Director Primacy: The Means and Ends of Corporate Governance. Univ. of California. Los Angeles School of Law Research Paper Series n 02-06, 2002.

The Short Life and Resurrection of SEC Rule 19C-4. In: Washington University Law Review. v. 69, Issue 2 In Memoriam: F. Hodge O'Neal. jan. 1991. Disponível em:

<https://openscholarship.wustl.edu/law_lawreview/vol69/iss2/6/>. Acesso em: 14 out. 2018.

BEBCHUK, Lucian A; ROE, Mark J. A theory of Path Dependence in Corporate and Governance and Ownership. Columbia Law School: The Center for Law and Economics. Working Paper n. 131, 1999.

BORTOLON, Patricia. Por que as empresas brasileiras adotam estruturas piramidais de controle. Base - Revista de Administração e Contabilidade da Unisinos 10(1): 2-18, jan./mar. 2013.

CHAYKOWSKI, Kathleen. Facebook Reports Strong First Quarter. Revenue, Earnings Beat Estimates. FORBES. Disponível em: $<$ https://www.forbes.com/sites/kathleenchaykowski/2017/05/03/facebookshares-rise-on-first-quarter-revenue-that-beat-estimates/\#380a62106b6d>. Acesso em: 14 out. 2018.

CHOI, Albert H. Concentrated Control and Long-Term Shareholder Value. n. 8. In: Harvard Business Law Review. 2018. Disponível em:

<http://www.hblr.org/wp-content/uploads/2018/09/8.1-Choi.pdf>. Acesso em: 16 set. 2018.

COMPARATO, Fabio Konder; SALOMÃO FILHO, Calixto. Poder de Controle na Sociedade Anônima. $5^{\mathrm{a}}$ ed. Rio de Janeiro: Ed. Forense, 2008.

CUNHA, Paulo Olavo. Direito das sociedades comerciais. $5^{\circ}$ ed. Coimbra, 2005.

DANAGGIO, Angela Rita Franco. Governança Corporativa e novo mercado: proteção ao investidor e falhas no marco regulatório. São Paulo: Ed. Saraiva, 2012. 
DEMSETZ, H.; LEHN, K. The Structure of Corporate Ownership: Causes and Consequences. The Journal of Political Economy. 1985. Disponível em: <http://dx.doi.org/10.1086/261354>. Acesso em: 04 nov. 2018.

; VILLALONGA, B. Ownership structure and corporate performance. Journal of Corporate Finance. 2001. Disponível em: <http://dx.doi.org/10.1016/S0929-1199(01)00020-7>. Acesso em: 04 nov. 2018.

DIMITROV, Valentin; JAIN, Prem C. Recapitalization of One Class of Common Stock into Dual Class: Growth and Long-Run Stock Returns, 12 J. Corp. Fin. 342, 347. 2006.

Disponível em:

$<$ http://ri.brmalls.com.br/conteudo_pt.asp?idioma $=0 \&$ conta $=28 \&$ tipo $=5085$ 4>. Acesso em: 03 nov.2018.

Disponível em: <http://sistemas.cvm.gov.br/dados/LaudEditOpa/RJ-200712218/20080306_POSPECTO_DE_OFERTA_P\%C3\%9ABLICA.pdf>. Acesso em: 05 nov.2018.

Disponível em: <http://sistemas.cvm.gov.br/dados/LaudEditOpa/RJ-200712218/20080306_POSPECTO_DE_OFERTA_P\%C3\%9ABLICA.pdf >. Acesso em: 05 nov.2018

Disponível em: <http://www2.camara.leg.br/legin/fed/decret/19301939/decreto-21536-15-junho-1932-517361-publicacaooriginal-1-pe.html > Acesso em: 05 nov.2018

Disponível em: 〈https://perma.cc/6UF8-EB9B>. Acesso em: 29 set. 2018.

Disponível em: <https://www.sec.gov/Article/whatwedo.html>. Acesso em: 06 out. 2018.

Disponível em:

<https://www.sec.gov/Archives/edgar/data/1402902/0001193125071

41382/df1.htm\#rom37482_14>. Acesso em: 17 nov. 2018.

Disponível em:

<http://construcaomercado17.pini.com.br/downloads/a_governanca_corpor ativa_e_o_mercado_de_capitais_13_14.pdf>. Acesso em: 26 out. 2018. 
Disponível em:

<http://www.camara.gov.br/proposicoesWeb/prop_mostrarintegra?codteor= 1680750>. Acesso em: 22 set. 2018.

Disponível em:

<http://www.cvm.gov.br/export/sites/cvm/decisoes/anexos/0010/8923-

2.pdf $>$. Acesso em: 04 nov. 2018.

Disponível em:

<http://www.bmfbovespa.com.br/pt_br/listagem/acoes/segmentos-delistagem/novo-mercado/>. Acesso em: 04 nov. 2018.

Disponível em:

<http://www.cvm.gov.br/export/sites/cvm/decisoes/anexos/0010/8923-

3.pdf>. Acesso em: 04 nov. 2018.

Disponível em:

<http://www.cvm.gov.br/export/sites/cvm/decisoes/anexos/0010/89230.pdf>. Acesso em: 04 nov. 2018.

Disponível em: <https://capitalaberto.com.br/temas/poucas-acoes-muitosvotos/\#.W_PuSjhKjIU>. Acesso em: 15 nov.2018

Disponível em:

<http://www.vale.com/brasil/PT/investors/company/shareholding-

structure/Paginas/default.aspx $>$. Acesso em: 03.11.2018.

Disponível em:

<https://ecgi.global/sites/default/files/working_papers/documents/SSRNid2574236.pdf>. Acesso em: 01 set. 2018.

Disponível em:

<https://www.bradespar.com.br/Bradespar/Portugues/Documentos/FR_Bra despar_Port_V3.pdf>. Acesso em: 04 nov. 2018.

Disponível em:

<https://www.rad.cvm.gov.br/enetconsulta/frmGerenciaPaginaFRE.aspx ?C odigoTipoInstituicao $=1 \&$ NumeroSequencialDocumento=78573>. Acesso em: 28 out. 2018.

Disponível em:

<https://www.rad.cvm.gov.br/enetconsulta/frmGerenciaPaginaFRE.aspx ?C odigoTipoInstituicao $=1 \&$ NumeroSequencialDocumento $=76072>$. Acesso em: 28 out. 2018 . 
Disponível em:

<https://www.sec.gov/Archives/edgar/data/1288776/000119312504073639/ ds1.htm>. Acesso em: 30 set. 2018.

Disponível em: <http://ri.bmfbovespa.com.br/static/ptb/perfilhistorico.asp?idioma=ptb>. Acesso em: 26 out. 2018.

Disponível em: <http://ri.gerdau.com/static/ptb/estruturasocietaria.asp?idioma=ptb>. Acesso em: 04 nov. 2018.

EIZIRIK, Nelson et al. Mercado de capitais - regime jurídico. $3^{\mathrm{a}}$ ed. rev. e amp. Rio de Janeiro: Renovar, 2011.

EIZIRIK, Nelson. A lei das S.A.., v. 2. $2^{\mathrm{a} e d . ~ S a o ~ P a u l o: ~ Q u a r t i e r ~ L a t i n, ~}$ 2015.

Aquisição de Controle Minoritário. Inexigibilidade de Oferta Pública In: Poder de Controle e outros Temas de Direito Societário e Mercado de Capitais. Quartier Latin, 2010.

O Mito do "Controle Gerencial": Alguns Dados Empíricos. Revista de Direito Mercantil Industrial, Econômico e Financeiro, São Paulo, ano XXVI, no 66, pp. 103-106, Abr/Jun. 1987.

FERRAN, Eilis. Examining the United Kindom's Experience in Adopting the Single Financial Regulator Model. In: n. 28 Brooklin Journal of International Law, 2003. Disponível em:

<http://brooklynworks.brooklaw.edu/bjil/vol28/iss2/2>. Acesso em: 25 out. 2018.

FISCHEL, Daniel R. Organized Exchanges and the Regulation of Dual Class Common Stock. In: University of Chicago Law Review. 1987. p. 136. Disponível em:

$<$ https://chicagounbound.uchicago.edu/journal_articles/1413/>. Acesso em: 14 out. 2018.

G. M. Hayden; M. T. Bodie. One Share, One Vote and the False Promise of Shareholder Homogeneity. In: Cardozo Law Review. BUS. Roundtable v. SEC, 905 F. 2d 406 (D.C. Cir. 1990), 2008. Disponível em: <https://scholarlycommons.law.hofstra.edu/faculty_scholarship/40/>.

Acesso em: 14 out. 2018.

GALGANI, Matthew. A Tale of 4 IPOs: Facebook, Alibaba, Snap and Square. INV'S. Bus. Daily (Oct. 21, 2017). Disponível em: 
<http://www.investors.com/how-to-invest/investors-corner/a-tale-of-4-iposfacebook-alibaba-snap-and-square/>. Acesso em: 14 out. 2018.

GONCALVEZ, Diogo Costa. Direitos especiais e o direito de exoneração em sede de fusão. O Direito, 2006. II, p. 313-362 (318).

GORGA, Érica R. Changing the Paradigm of Stock Ownership from Concentrated Towards Dispersed Ownership? Evidence from Brazil and Consequences for Emerging Countries. Cornell Law School Working Papers n.42, set., 2008. Disponível em:

$<$ https://scholarship.law.cornell.edu/clsops_papers/42/> Acesso em: 26 out. 2018.

GOSHEN, Zohar; HAMDANI, Assaf. Corporate Control and Idiosyncratic Vision. n. 125. In: Yale Law Journal, 2016. p. 56. Disponível em: $<$ https://www.yalelawjournal.org/article/corporate-control-andidiosyncratic-vision>. Acesso em: 16 out. 2018.

et al. The Essential Role of Securities Regulation. 55 DUKE L.J. 711, 714. 2006.

; SQUIRE, Richard. Principal Costs: A New Theory for Corporate Law and Governance. $\mathrm{n}^{\mathrm{o}}$ 117. Columbia Law. Rev., 2017.

HALLQVIST, B. Código das melhores práticas de governança corporativa - o conselho de administração. Revista de Administração, v. 35, nº 2, p. 72$76,2000$.

HENN, Harry G. ALEXANDER, John R. Laws of Corporations. St. Paul, Minnesota: West Publishing Co. Third Edition, 1983.

HIMMELBERG, C.P.; HUBBARD, R.G.; PALIA, D. Understanding the determinants of managerial ownership and the link between ownership and performance. Journal of Financial Economics, 53: 1999.

HIRSCH, Lauren. Snap's Shares Pop After Year's Biggest. In: IPO, Reuters. mar. 2, 2017. 01:06 am. Disponível em:

<http://www.reuters.com/article/us-snap-ipo-idUSKBN1690I7>. Acesso em: 27 out. 2018.

IBGC Instituto Brasileiro de Governança Corporativa. Governança Corporativa em empresas de controle familiar: casos de destaque no Brasil. São Paulo: Saint Paul Editora, 2007. 
JENSEN, Michael C.; MECKLING, William H. Theory of the Firm: Managerial Behavior, Agency Costs and Ownership Structure. Journal of Financial Economics. oct., v. 3, no .4 .1976$.

KAHAN, Marcel; ROCK, Edward. Hedge Funds in corporate governance \& corporate control. In: University of Pennsylvania Law Review. v. 155, 2017. p. 1021. Disponível em:

<https://papers.ssrn.com/sol3/papers.cfm?abstract_id=1291580>. Acesso em: 21 out. 2018.

KONRAD, Alex. Snap's IPO Means a Huge Windfall for These VC Investors. In: FORBES. Disponivel em:

<https://www.forbes.com/sites/alexkonrad/2017/02/02/snap-ipo-means-bigwindfall-for-early-snapchat-investors/\#285ed30ab414>. Acesso em: 16 out. 2018.

KORNERT, Jan. The Barings Crises of 1890 and 1995: Causes, Courses, Consequences and the Danger of Domino Effects. In Journal of International Financial Markets, Institutions and Money, 13, $\mathrm{n}^{\mathrm{o}}$ 3, jul., 2003.

L. ENRIQUES, R.J.; GILSON, A.M. Pacces. The Case for an Unbiased Takeover Law (With an Application to the European Union). In: Harvard Business Law Review, 2014.

LA PORTA, R.; LOPEZ DE SILANEZ, F; SHLEIFER, A. Corporate ownership around the world. Journal of Finance, v.54, n. 2, p.471-517, 1999.

LAMY FILHO, Alfredo; PEDREIRA, José Luiz Bulhões (Coord.). Direito das companhias. $2^{\mathrm{a}}$ ed. atual. refor. Rio de Janeiro: GEN, Forense, 2017.

;___ A Lei das S.A. v. 2, 2ª ed. Rio de Janeiro: Renovar, 1996.

LASHINSKY, Adam. Why NBC Universal Got In on Snap's IPO. In: Fortune, out. 27, 2018. Disponível em:

<http://fortune.com/2017/03/06/why-nbc-universal-got-inon-snaps-ipo/>. Acesso em: 16 out. 2018.

LEAL, R.P.C; CARVALHAL DA SILVA, A. L; VALADARES, S. M. Estrutura de Controle das Companhias Brasileiras de Capital Aberto. Revista de Administração Contemporânea. v. 6, n. 1, 2002. 
LIM, U; KIM, C. Determinants of ownership structure: an empirical study of Korean conglomerates. Pacific-Basin Finance Journal. 13, 2005.

MICKLETWAIT, John; WOOLDRIDGE, Adrian. DUARTE, S. (trad.) A Companhia: Breve História de ma Ideia Revolucionária. Rio de Janeiro: Objetiva, 2003., p. 104.

MUSSNICH, Francisco Antunes Maciel. Voto Plural: Quebrando Paradigmas. Disponível em:

$<$ https://www.valor.com.br/legislacao/5228253/voto-plural-quebrandoparadigmas >. Acesso em: 28 out. 2018.

OLIVEIRA, Madalena Perestrelo de. Direito de voto nas Sociedades Cotadas Portuguesas: da admissibilidade de categorias de ações com direito de voto plural às L-Shares. Revista de Direito das Sociedades e dos Valores

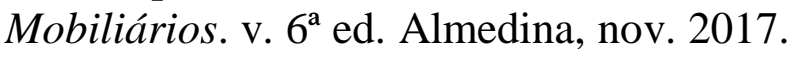

ORESKOVIC, Alexei. Everyone thought Mark Zuckerberg was crazy to buy a 13-person app for $\$ 1$ billion - Now instagram looks like one of the most brilliant tech acquisitions ever made, bus. INSIDER. Disponível em: $<$ http://www.businessinsider.com/instagram-zuckerbergs-biggest-win-sofar-2016-1>. Acesso em: 08 out. 2018.

PARENTE, Norma Jonssen. O Direito de Recesso na Incorporação, Fusão ou Cisão de Sociedades. In: Revista de Direito Mercantil, Industrial, Econômico e Financeiro. São Paulo, Ano XXXIV, n. 97, p. 67-75, jan/mar. 1995.

PARTCH, Megan. The Creation of a Class of Limited Voting Common Stock and Shareholder Wealth, n. 18 J. Fin. Econ., 1987.

PEIXOTO, Fernanda Maciel; BUCCINI, Aline Rabelo Assis. Separação entre propriedade e controle e sua relação com desempenho e valor de empresas brasileiras: onde estamos? Revista de Contabilidade $e$ Organizações. $\mathrm{n}^{\circ}$ 17, p.48-59, 2013.

PUC-Rio. Departamento de Direito. Direito Empresarial Estudos Contemporâneos. Grupo de Direito Empresarial da PUC-Rio, Ed. Quartier Latin. CRISTÓFARO, Pedro Paulo; MACHADO FILHO, Caio (Coord.). 2017.

RANDEWICH, Noel. Snap Surges After Wall Street Heavyweights Reveal Stakes. In: Reuters. out. 27, 2018, 10:10 hs. Disponível em: 
<http://www.reuters.com/article/snap-stocks-idUSL2N1IH0XV>. Acesso em: 27 out. 2018.

RODRIGUES, Usha. Corporate Governance in an age of separation of ownership for ownership. In: Minnesota Law Review. v. 95 1822-1866, 2011. Disponível em:

$<$ https://papers.ssrn.com/sol3/papers.cfm?abstract_id=1736611>. Acesso em: 21 out. 2018.

ROSE, Paul; SHARFMAN, Bernard S. Shareholder activism as a corrective mechanism in corporate governance. 2014 BYU L. REV. p.1015, 2014. Disponível em:

$<$ https://digitalcommons.law.byu.edu/cgi/viewcontent.cgi?article=2943\&co ntext=lawreview >. Acesso em: 28 out. 2018.

SALOMÃO NETO, Eduardo. O trust no Direito Brasileiro. São Paulo: LTR, 1996.

SANTOS, João Vieira dos. Ações de Lealdade. A primazia dos interesses da estabilidade a longo prazo da empresa social. Revista de Direito das Sociedades, $\mathrm{n}^{\mathbf{0}}$ 2, 2014.

SELIGMAN, Joel. Equal Protection in Shareholder Voting Rights: The One Common Share, One Vote Controversy, 54 George Washington Law Review. p. 687-697, 1986.

SHARFMAN, Bernard S. A Private Ordering Defense of a Company's Right to Use Dual Class Share Structures in IPOs. 63. In: Vill. L. Rev. 1. 2018.

SIFFERT FILHO, N. Governança corporativa: padrões internacionais e evidências empíricas no Brasil nos anos 90. Revista do BNDES, $\mathrm{n}^{\circ}$ 9, jun. 1998.

SILVA, André Luiz Carvalhal da. A Influência da Estrutura de Controle e Propriedade no Valor, Estrutura de Capital e Política de Dividendos das Empresas Brasileiras. Rio de Janeiro, 2002. vii, 128 f.: il. Tese (Doutorado em Administração) - Universidade Federal do Rio de Janeiro - UFRJ, Instituto COPPEAD de Administração, 2002.

; LEAL, R. P. C. Ownership, control, valuation and performance of brazilian corporations. Corporate Ownership and Control. v .4, n. 1, p. 300-308, 2006. 
SILVA, Carlos Alexandre Lobo e. A evolução da aquisição de controle de companhias abertas no Brasil. In: SILVA, Alexandre Couto (Coord.). Direito societário. São Paulo: Saraiva, 2013.

SIQUEIRA, T. Concentração da Propriedade nas Empresas Brasileiras de Capital Aberto. Revista do BNDES, $\mathrm{n}^{\circ}$ 10, dez. 1998.

STEVENS, W.H.S. Stockholders`Voting Rights and the Centralization of Voting Control. 40 Q. J. Econ. 1926.

STRINE Jr., Leo E. Why excessive risk-taking is not unexpected. New York Times. Oct. 5, 2009. Disponível em: <https://dealbook.nytimes.com/2009/10/05/dealbook-dialogue-leo-strine/>. Acesso em: 10 nov. 2018.

The Many Facades of BCCI. Revista The Economist. v. 320, $\mathrm{n}^{\mathrm{o}} 7715$, 13.07.1991.

TURNER, Jonathan A. The Turner Review, A Regulatory Response to the Global Banking Crisis. S.1.: s.n., mar., 2009. Disponível em: <http://fsa.gov.uk/pubs/other/turner_review.pdf>. Acesso em: 06 out. 2018.

USP. Revista Contabilidade \& Finanças. São Paulo, v. 21, n. 52, jan./abr. 2010.

W. Ripley. Main Street and Wall Street. Little, Brown and Company. Boston, 1927.

ZHAO, Jingchen. Corporate social responsibility in contemporary China. Massachusetts, 2014. 


\title{
ANEXO I
}

\section{PROJETO DE LEI № 10.736, DE 2018}

\author{
(Do Sr. CARLOS BEZERRA)
}

Acrescenta o art. 110-A à Lei $n^{\circ}$ 6.404, de 15 de dezembro de 1976, de modo a autorizar a atribuição de voto plural a uma única classe de ações, e dá outras providências.

O Congresso Nacional decreta:

Art. $1^{\circ}$ Esta Lei autoriza a atribuição de voto plural a uma única classe de ações, nas condições que especifica.

Art. $2^{\circ} \mathrm{O}$ art. 16 Lei $\mathrm{n}^{\circ}$ 6.404, de 15 de dezembro de 1976, passa a viger com a seguinte redação:

“Art.

16. 
IV - atribuição de voto plural a uma única classe de ações de titularidade de empreendedor ou fundador, nos termos do art. 110-A.

" (NR)

Art. $3^{\circ}$ A Lei $n^{\circ}$ 6.404, de 15 de dezembro de 1976, passa a viger acrescida do seguinte artigo:

"Art. 110-A. Fica autorizado atribuir voto plural a uma única classe de ações ordinárias na companhia fechada.

$\S 1^{\circ} \mathrm{O}$ prazo máximo de vigência do voto plural não excederá três anos, permitida uma única prorrogação pelo mesmo período.

$\S 2^{\circ}$ A criação da única classe de ações ordinárias e a eficácia da deliberação de sua prorrogação dependem de prévia aprovação ou de ratificação, em prazo improrrogável de noventa dias contados da assembleia geral extraordinária, de acionistas titulares de mais da metade das ações ordinárias em circulação, reunidos em assembleia especial convocada e instalada com as formalidades desta Lei, não computados os votos dos titulares de ações com voto plural.

$\S 3^{\circ}$ Findo o prazo de vigência, as ações ordinárias com voto plural voltarão a ter apenas 1 (um) voto nas deliberações da assembleia-geral. 
$\S 4^{\circ}$ No caso de atribuição de voto plural a classe de ações de titularidade de empreendedor ou fundador da companhia, é lícito estipular o início da respectiva vigência ao término da execução do plano de negócios contratado desde que por prazo não superior a seis anos.

$\S 5^{\circ} \mathrm{O}$ voto plural conferido a uma única classe de ações ordinárias permanecerá em vigor ainda que a companhia tenha seus valores mobiliários admitidos a negociação em quaisquer segmentos de listagem de bolsa de valor ou de mercado de balcão organizado." (NR)

Art. $4^{\circ}$ Fica revogado o $\S 2^{\circ}$ do art. 110 da Lei $n^{\circ} 6.404$, de 15 de dezembro de 1976, renumerando-se os demais parágrafos.

Art. $5^{\circ}$ Esta lei entra em vigor na data de sua publicação.

\section{JUSTIFICAÇÃO}

Ainda que o preceito "uma ação, um voto" seja considerado dogma de boa governança corporativa, esse princípio não é unanimemente aceito e tem sido reconsiderado por diversas jurisdições que o adotam, de forma a atender às necessidades dos mercados locais.

O descasamento entre direitos econômicos e políticos dentro da companhia é aceito em países como Argentina, Holanda, Suécia, Dinamarca, EUA, França e Itália. As bolsas de valores de Cingapura e 
Hong Kong, que terminantemente vedavam IPOs (Inicial Public Offering ou oferta pública inicial) de companhias que contassem com ações com direito de voto restrito, estão prestes a rever esse posicionamento.

As mais importantes listagens em bolsa utilizaram-se do expediente. Gigantes da tecnologia como Google, LinkedIn, Facebook, Snapchat e Alibaba abriram seu capital fazendo uso de classes diferenciadas de ações em sua estrutura societária.

Seguindo a tendência internacional e atendendo à necessidade das companhias domésticas, esta proposição foi inspirada pelo texto "Voto plural: quebrando paradigmas", de autoria do jurista Francisco Müssnich, publicado do Jornal Valor Econômico em dezembro de 2017, e visa a eliminar do nosso ordenamento jurídico a vedação à atribuição de voto plural às ações, prevista no art. 110, § 2 $2^{\circ}$, da Lei de Sociedades Anônimas.

Informa Müssnich que, no Brasil, o preceito "uma ação, um voto" é adotado desde 1940, quando se estabeleceu que a cada ação ordinária de uma companhia corresponde um voto nas deliberações da assembleiageral, preservando-se, assim, a proporcionalidade entre capital investido e controle societário. Para o autor, o combalido mercado local muito se beneficiaria da revisão desse marco legal.

De fato, a atribuição de voto plural a uma classe de ações configura estratégia com elevado potencial de incentivar a listagem em bolsa de companhias familiares e start-ups. Isso porque, essas são companhias cujo capital reputacional está, em regra, intimamente ligado a um fundador ou empreendedor. Atribuir-lhes voto plural é assegurar que acionistas-chave preservarão seu poder de controle, no cenário pós-abertura de capital, o que gera confiança - tanto para os demais acionistas quanto para potenciais investidores - na continuidade do padrão gerencial da companhia. 
Dado que o direito brasileiro já permite o descasamento entre direitos econômicos e políticos por meio do uso de ações preferenciais, estruturas piramidais e de propriedade cruzada, indaga-se: por que não se autorizar o voto plural? Diversas listagens domésticas, em especial de companhias do setor de transporte aéreo, recorreram a intrincada engenharia societária com o intuito de conferir o poder de controle a determinado acionista minoritário. Acreditamos que o voto plural é mecanismo mais transparente para atingir fim similar.

Tendo por norte o delineamento de regras claras para atribuição e exercício do voto plural, sugerimos a inserção de um artigo 110-A à Lei de Sociedades Anônimas. Na proposta que submetemos à apreciação das Casas deste Congresso Nacional, o prazo de vigência do voto plural não excederá três anos, permitida uma única prorrogação por igual prazo. A anuência dos acionistas não titulares de ações com voto plural, seja via aprovação prévia ou ratificação em assembleia, é pré-requisito para criação dessa classe de ações. Por fim, com o intuito de evitar quaisquer discussões futuras, esclarece-se que o voto plural é compatível com os requisitos de governança dos segmentos especiais de listagem.

Ciente da relevância da proposição para a retomada do desenvolvimento do mercado doméstico e para a diversificação das oportunidades de investimento, solicito o apoio de meus Pares para que este projeto de lei tenha tramitação célere e, por fim, bem-sucedida.

Sala das Sessões, em [-] de [-] de 2018.

Deputado CARLOS BEZERRA 